\title{
Ultrapotassic Mafic Dikes and Rare Earth Element- and Barium-Rich Carbonatite at Mountain Pass, Mojave Desert, Southern California: Summary and Field Trip Localities
}

by Gordon B. Haxel

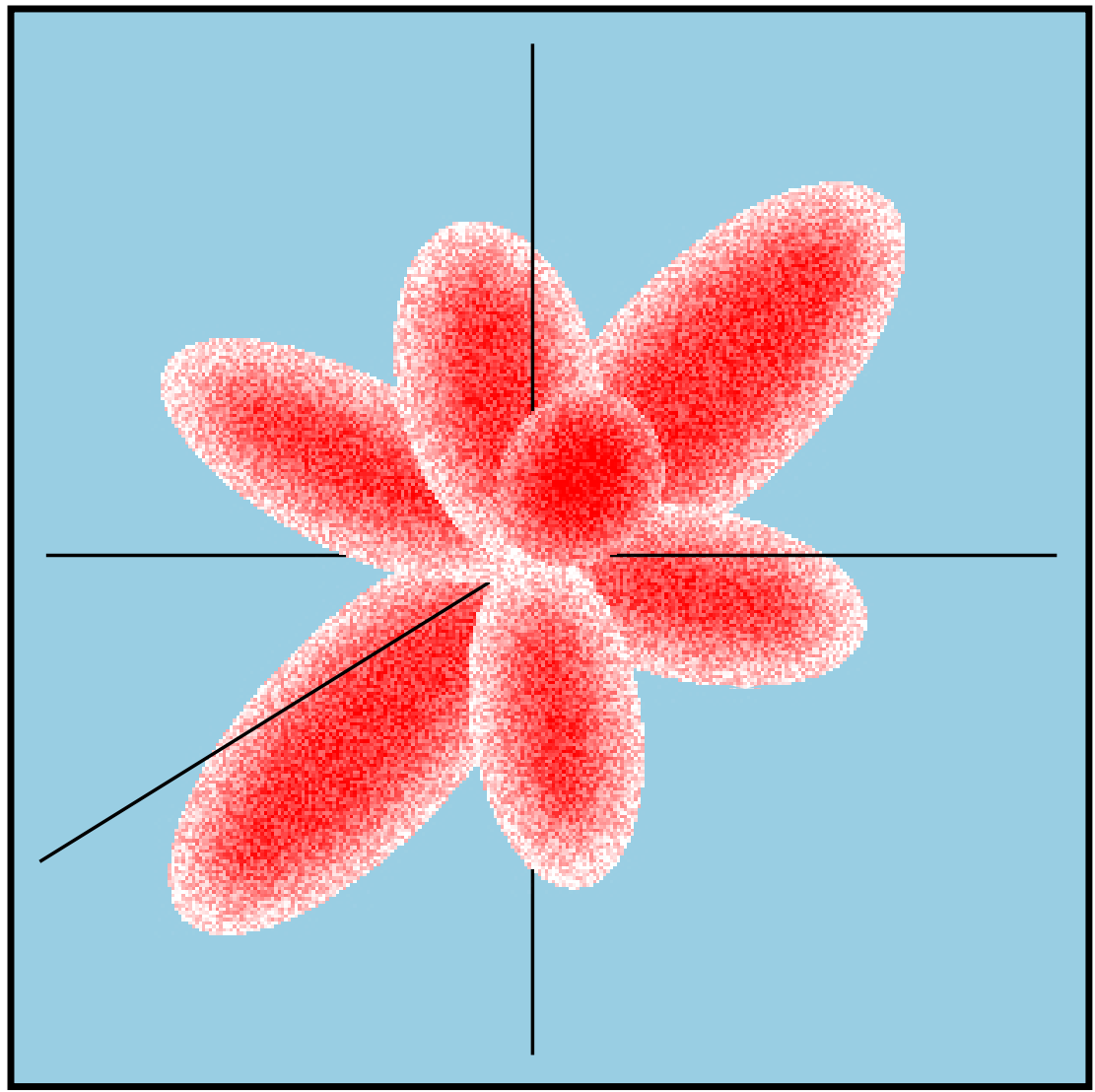

Schematic representation of the probability density function for one of the forbitals. Progressive filling of the $4 \mathrm{f}$ orbitals characterizes the fifteen lanthanide (rare earth) elements, lanthanum through lutetium.

Open-File Report 2005-1219

2005

Any use of trade, firm, or product names is for descriptive purposes only and does not imply endorsement by the U.S. Government. U.S. DEPARTMENT OF THE INTERIOR U.S. GEOLOGICAL SURVEY 


\section{Ultrapotassic Mafic Dikes and Rare Earth Element- and Barium-Rich Carbonatite at Mountain Pass, Mojave Desert, Southern California: Summary and Field Trip Localities}

Gordon B. Haxel

Rare Earth Element Resource Specialist

U.S. Geological Survey

2255 N. Gemini Dr.

Flagstaff, Arizona 86001

The Mountain Pass Rare Earth Element District

Mountain Pass, California is famous for its world-class rare earth element deposit, hosted by a compositionally unique carbonatite stock (Olsen and others, 1954; DeWitt, 1987; Castor, 1990, 1991, 1994; Haxel, in press 1). This carbonatite contains extraordinary large concentrations of the lighter rare earth elements ( $\mathrm{La}-\mathrm{Gd}$ ) and $\mathrm{Ba}$, and is one of the most compositionally extreme, even bizarre, igneous rocks known on Earth. Mountain Pass also features a remarkable suite of silicate alkaline igneous rocks, distinguished by their ultrapotassic character and exceptionally high abundances of rare earth elements, F, Th, and large-ion-lithophile elements (K, Ba, Rb, Cs). Of particular interest are certain phlogopite shonkinite (melanosyenite) dikes that evidently represent the primary, parental silicate magmas at Mountain Pass.

I prepared this informal article to provide petrologic and geochemical background for a field trip to the Mountain Pass district by the Arizona Geological Society in October 2004. The highlight of this trip was a tour of the Mountain Pass rare earth element mine, including the open pit and processing facilities, lead by Geoff Nason and Ed McNew of Molycorp, the company that owns and operates the mine. Following the mine tour, we visited two other geologic features: a carbonatite dike at Birthday, the discovery locality for the district; and synplutonic shonkinite dikes within a shonkinite-syenite stock. We concluded the field trip by driving up a nearby hill for an overview of the Mountain Pass district. The synplutonic-dike and overview localities, and a couple of others nearby, are described in the Appendix.

The Figures that accompany this article, most originally prepared as color slides for oral presentations, are grouped at the end. Table 1 appears after the text and before the Figures. A USGS Fact Sheet (Haxel and others, 2002) summarizing technological applications, abundances, resources, and supply issues of the rare earth elements follows this article.

The Rare Earth Elements

Because Mountain Pass is renowned as a source of rare earth elements, description of the remarkable igneous rocks of the district is best preceded by a brief introduction to several aspects of the rare earth elements (REE) themselves. 
The REE form the most chemically coherent group in the entire periodic table (Fig. 1; Cotton, 1991; Rossotti, 1998; Kaltsoyannis and Scott, 1999). Rare earth elements, as generally used in geochemistry, refers to exactly 15 elements: the lanthanides, La through Lu, except for Pm, plus Y (Table 1; Henderson, 1984; Lipin and McKay, 1989; Kilbourn, 1993a, 1994; Jones and others, 1996; Orris and Haxel, in press). Promethium is excluded because it has no long-lived isotopes and occurs naturally on Earth only locally and in vanishingly small quantities. The geochemical behavior of $Y$ is virtually identical to that of the heavier lanthanides, particularly Dy and Ho (Figs. 1, 2A). Though sometimes incorrectly included therein, Sc and Th are not REE. Light REE (LREE) refers to La - Sm; heavy REE (HREE) to Gd - Lu and Y. The symbol Ln represents any or all of the lanthanides or REE, depending upon context.

Separation and identification of all fifteen of the naturally occurring REE required more than a century, from 1794 to 1907 . The final REE to be isolated, Lu, was the third-to-last of the 83 stable or long-lived chemical elements to be discovered (followed only by $\mathrm{Hf}$ and $\mathrm{Re}$ ). Even after nearly all of the them had been discovered, the lanthanides remained problematic because they seemed not to fit into the periodic table:

"In point of respectability your radium family will be a Sunday school compared with the [rare earth elements], whose [chemical] behavior is simply outrageous. It is absolutely demoralizing to have anything to do with them." (B. Boltwood, 1905; quoted in Taylor and McLennan, 1985). "The rare earths perplex us in our researches, baffle us in our speculations, and haunt us in our very dreams. They stretch like an unknown sea before us, mocking, mystifying, and murmuring strange revelations and possibilities." (W. Crookes, 1902; quoted in Rayner-Canham, 1996).

These conundrums were finally resolved during the early stages of the development of quantum theory, circa 1910, with the realization that the fourteen lanthanides from $\mathrm{La}$ through $\mathrm{Yb}$ belonged to a previously unknown domain of the periodic table, the f block (Fig. 1).

Primary controls of the geochemical behavior, pathways, and distribution of the REE are charge (oxidation state) and ionic radius. The REE are predominantly trivalent; only two exceptions occur in Nature (Table 1; Fig. 2A). In surficial environments, Ce may be partially or largely oxidized to $\mathrm{Ce}^{4+}$, causing its behavior to be decoupled from that of the other REE. Consequently, REE spectra of seawater and many marine authigenic or biogenic sedimentary rocks show so-called cerium anomalies (Fig. 2B). In reduced environments, such as many magmas, Eu frequently is partially divalent. This property accounts for the familiar europium anomalies in the REE spectra of many igneous rocks. Ionic radii of the trivalent lanthanides decrease progressively from La to Lu (Fig. 2A). Owing to this lanthanide contraction, the LREE are somewhat more incompatible than the HREE. 
In Earth's upper continental crust, concentrations of $Y$ and the three most common LREE - La, Ce, and Nd - are $20-60 \mu \mathrm{g} / \mathrm{g}$, comparable to those of $\mathrm{Cu}, \mathrm{Zn}$, and $\mathrm{Pb}$. Concentrations of the least common HREE, Tm and Lu, are $\sim 0.3$ $\mu \mathrm{g} / \mathrm{g}$, about 6 times the average upper crustal abundance of $\mathrm{Ag}$.

Figure 3 illustrates representative chondrite-normalized (cn; Table 1) REE spectra of diverse suites of igneous rocks, ranging from alpine peridotite and MORB to carbonatite, including shonkinite and carbonatite from Mountain Pass. In this diagram, steeper negative slopes indicate greater fractionation of LREE relative to HREE (and vice versa). The degree of REE fractionation is quantified by the ratio $(\mathrm{La} / \mathrm{Yb})_{\mathrm{cn}}$ (where $\mathrm{cn}$ denotes chondritic normalization; Table 1 ). This parameter ranges from $<1$ for typical MORB to 9 for average upper continental crust, to $>30$ for many alkaline silicate igneous rocks, to $>100$ for most carbonatites.

In the solid state and in commerce, principal oxides of the REE are the sesquioxides, $\mathrm{Ln}_{2} \mathrm{O}_{3}$. Cerium oxide may be specified as either $\mathrm{Ce}_{2} \mathrm{O}_{3}$ or $\mathrm{CeO}_{2}$. Techniques for separation and purification of Eu take advantage of its two oxidation states, but the final product is normally $\mathrm{Eu}_{2} \mathrm{O}_{3}$. Oxides of $\mathrm{Pr}$ and $\mathrm{Tb}$, commonly nonstoichiometric, contain both $\mathrm{Ln}^{3+}$ and $\mathrm{Ln}^{4+}$ and are customarily designated by the approximate formulas $\operatorname{Pr}_{6} \mathrm{O}_{11}$ and $\mathrm{Tb}_{4} \mathrm{O}_{7}$. Cerium is unique among the REE in that both of its oxidation states are readily accessible in aqueous solution. Several specialized applications of $\mathrm{Ce}$, notably polishing of glass, exploit this property (Kilbourn, 1992, 1993b).

Geographic and Geologic Setting of Mountain Pass

The Mountain Pass (MP) district is located in the upper Mojave Desert of southeast California, at elevations of 1300 - 1700 m (4300 - 5600 feet); about $80 \mathrm{~km}$ southwest of Las Vegas, Nevada (Fig. 4). Interstate 15, connecting Las Vegas and Los Angeles, bisects the district. To the north, west, and south the MP district is largely surrounded by the Mojave National Preserve.

The crystalline bedrock of the MP area (Fig. 5) is part of the autochthon beneath the basal fault of the late Mesozoic Sevier thrust belt (Hewitt, 1956; Burchfiel and Davis, 1971, 1988; Fleck and others, 1994; Theodore, in press). This terrane comprises high-grade gneiss, amphibolite, and gneissic pegmatite, of Paleoproterozoic age, 1.8 - 1.6 Ga (Wooden and Miller, 1990). Around MP, these metamorphic rocks are intruded by Mesoproterozoic ultrapotassic rocks and carbonatite, which are unmetamorphosed. The ultrapotassic igneous rocks and carbonatite are $\approx 1.4 \mathrm{Ga}$ (DeWitt and others, 1987), several hundred million years younger than and unrelated to their gneissic country rocks. Both groups of Proterozoic rocks are widely intruded by Mesozoic or Tertiary andesitic and rhyolitic dikes. Several kilometers to the north, Paleoproterozoic crystalline rocks like those of the MP district are depositionally overlain by latest Neoproterozoic and Cambrian strata, unmetamorphosed and gently west-dipping (Jennings, 1961; Evans, 1971; Miller and others, in press). 
Most of the region of the Basin and Range province surrounding MP has undergone profound Cenozoic crustal extension (Friedmann and others, 1996; Faulds and others, 2001). The relatively high-standing block of the eastern Mojave Desert that includes MP is unusual in that it has not been strongly extended. The contrast between extended and unextended terranes is emphasized by comparison of the attitudes of pre- to synextensional middle Miocene volcanic rocks. Volcanic rocks within highly extended terrane east of MP have been steeply tilted, as much as $90^{\circ}$ (Miller and others, 2005). Ignimbrites erupted from a caldera to the south, within the same structural block as MP, remain horizontal (McCurry, 1988). Had MP been as highly extended and tilted as surrounding areas, its unique ultrapotassic rocks and carbonatite quite possibly would not be preserved or exposed. The alkaline rocks and carbonatite at MP also escaped Mesozoic metamorphism, which degraded Mesoproterozoic ultrapotassic rocks farther south in the Mojave Desert (Castor and Gleason, 1989).

Ultrapotassic Silicate Igneous Rocks

Distribution and petrology

The ultrapotassic silicate igneous rocks at MP form seven stocks and hundreds of dikes (Fig. 5; Olson and others, 1954; Crow, 1984; DeWitt, 1987; Morton and others, 1991; Haxel, in press 1). The largest stock, adjacent to the carbonatite intrusion that hosts the REE deposit, is about $2 \mathrm{~km}$ long by 0.5 wide. The other six stocks, in the southern part of the district, are considerably smaller, $\sim 0.1-0.5 \mathrm{~km}$ in largest map dimension. The rocks that make up these stocks and the numerous dikes range in composition from phlogopitite and phlogopite shonkinite (melano-syenite; Mitchell, 1996b, c) through amphibolebiotite mesosyenite and leucosyenite to alkali granite. Genetically, the most important of these are the shonkinite dikes, some of which have primitive compositions and evidently represent the parental silicate magmas of the MP district.

The shonkinite-syenite stocks are petrogenetically complex. They are products of crystal fractionation, so each rock represents some mixture of accumulated crystals and residual liquid, in uncertain proportions. Furthermore, synplutonic dikes within the Tors shonkinite-syenite stock (Fig. 5) indicate repeated introduction of new magma into the stock during crystallization (see Appendix). The dikes are back-intruded by the host shonkinite and syenite, and dike magmas widely mingled and locally mixed (Pitcher, 1993; Hibbard, 1995) with their hosts. So, the dikes are not necessarily compositionally pristine. Given this complex history, neither the bulk composition nor the parental composition of the shonkinite-syenite stock is necessarily preserved in any single rock. The leucosyenite and granite stocks are potentially even more complicated, as their origin may have involved crustal contamination or assimilation as well as fractional crystallization. These uncertainties can be circumvented by studying the shonkinite dikes, for which parental compositions can be more readily identified. In this summary I emphasize the shonkinite dikes, with little further consideration of the stocks, nor the syenite and granite dikes (Fig. 5). 
Petrographically, the shonkinite dikes are fine- to medium-grained; and mediumto dark-gray, with color indices typically about 40 to 70 percent. They comprise subequal proportions of just three essential minerals: Ba- and Ti-bearing fluorphlogopite (to biotite), microperthitic microcline, and augite or aegirine. Phlogopite forms small ( $0.5-5 \mathrm{~mm})$ phenocrysts set in a groundmass of all three minerals. Some samples contain accessory quartz; feldspathoids and olivine are absent. Other common accessory minerals include $\mathrm{Na}$-amphibole, plagioclase, apatite (2 - $5 \%)$, Fe-Ti oxides, and zircon.

The shonkinite dikes evidently are silica-saturated to slightly oversaturated. In their molar proportions of alkali oxides and alumina, they range from marginally metaluminous to marginally peralkaline. These shonkinites contain so much barium (see below) that $\mathrm{BaO}$ should be included with $\mathrm{Na}_{2} \mathrm{O}$ and $\mathrm{K}_{2} \mathrm{O}$ in calculating alkali saturation (Table 2). If this is done, more than one-half of the samples are slightly peralkaline. As a consequence of high $\mathrm{K}_{2} \mathrm{O}$ and low alumina, the shonkinites also have unusually high molar $\mathrm{K}_{2} \mathrm{O} / \mathrm{Al}_{2} \mathrm{O}_{3}$, average . 0.8. In contrast, the great majority of igneous rocks have molar $\mathrm{K}_{2} \mathrm{O} / \mathrm{Al}_{2} \mathrm{O}_{3} \leq 0.3$ (Bergman, 1987).

Some of the shonkinite dikes at MP have previously been called minette. Although they do resemble minette petrographically, the shonkinites are so different from typical minettes in their major and trace element geochemistry as to render the term inappropriate. In particular, the shonkinites are ultrapotassic (see below), whereas minettes in general are not, and have decisively higher $\mathrm{K}_{2} \mathrm{O} / \mathrm{Al}_{2} \mathrm{O}_{3}$ than minettes (Haxel, in press 1 ). Moreover, concentrations of a number of petrogenetically significant trace elements far exceed levels characteristic of minettes:

\begin{tabular}{cccc} 
& $\begin{array}{c}\text { Mountain Pass } \\
\text { primary shonkinite } \\
(\text { median, } \mu \mathrm{g} / \mathrm{g})\end{array}$ & & $\begin{array}{c}\text { Minette (overall } \\
\text { average, } \mu \mathrm{g} / \mathrm{g}) \\
\text { (Rock, 1991) }\end{array}$ \\
\cline { 2 - 2 } $\mathrm{F}$ & 9700 & & 2400 \\
$\mathrm{Cs}$ & 6.4 & & 2.0 \\
$\mathrm{Ba}$ & 8100 & 1800 \\
$\mathrm{La}$ & 450 & 86 \\
$\mathrm{Ce}$ & 960 & 176 \\
Th & 140 & 26
\end{tabular}

Some of these and other differences are illustrated in Figures 6 though 9 . Rather than minette, the fine-grained shonkinitic dike rocks at Mountain Pass are best called microshonkinite.

Geochemically, two characteristics of the shonkinite dikes at MP are fundamental: (1) they are magnesian and have high concentrations of compatible elements; (2) they are ultrapotassic and remarkably rich in a number of incompatible elements (Table 2).

Compatible elements and primary magmas

In general, primary, mantle-derived magmas are characterized by high $\mathrm{MgO}$, $\mathrm{Mg} / \mathrm{Fe}$, and $m g$ (Mg number: Table 2) and by large concentrations of strongly 
compatible trace elements such as Sc, $\mathrm{Cr}$, Co, and Ni. For tholeiitic, calcalkaline, and ordinary alkaline igneous rocks, typical primitive compositions are $\mathrm{MgO} * 8$ percent, $m g \sim 0.7$, and $\mathrm{Ni}$ and $\mathrm{Cr} \sim 100-300 \mu \mathrm{g} / \mathrm{g}$ (Rock, 1991; Nixon and Johnston, 1997). Primary ultrapotassic magmas may have slightly lower or higher $m g$ (Foley, 1992; Luhr, 1997). Figure 10 shows the ranges of values of $m g$ and Ni commonly consid-ered diagnostic of primary magmas. By the less restrictive criteria shown, many or most of the shonkinite dikes at MP could be primary. By even the most restrictive criteria, the five dikes with $m g .0 .76$ and $\mathrm{Ni} .350 \mu \mathrm{g} / \mathrm{g}$ have primary compositions.

Four of these five most-primitive dikes are members of a diffuse, sparse cluster of dikes in the southernmost part of the MP district $(0.1-2 \mathrm{~km}$ south of the area shown in Fig. 5). All four are composed of microshonkinite. These dikes are quite small: $200-600 \mathrm{~m}$ long, and only $0.25-1.5 \mathrm{~m}$ thick. Intrusive contacts are sharp, with no evidence of chemical reaction or mechanical interaction (other than simple intrusion) between the dikes and their country rock. Arguably, such thin, isolated dikes cooled quickly because of their high ratio of surface area to volume, and lacked the mass and thermal energy required to assimilate crustal material. Elevated volatile contents $\left(\mathrm{F} .1 .0 \%, \mathrm{H}_{2} \mathrm{O} .0 .7 \%\right)$ likewise suggest rapid emplacement and cooling, and therefore minimal crustal interaction. Furthermore, high contents of incompatible elements, typically 4 17 times greater than average upper continental crust, effectively buffered the dikes against significant crustal contamination.

These dikes also show no evidence that their magnesian and compatibleelement-rich character owes to concentration or incorporation of accumulative material. They are texturally homogeneous, without zoning or indication of crystal concentration by internal mechanical differentiation. They have homogeneous populations of small $(0.5-2 \mathrm{~mm})$ phlogopite phenocrysts evenly distributed in a uniform, fine-grained groundmass. Cognate inclusions, megacrysts, or glomeroporphyritic clots that might suggest an accumulative component are absent.

Thus, geochemical data, field relations, and petrographic observations together indicate that the most-primitive dikes at MP crystallized from primary magmas, derived directly from the mantle and emplaced into the upper crust without significant crustal interaction. I interpret these four very similar microshonkinite dikes (Figs. 6, 8-10) as representing the primary, parental silicate magma of the MP district. Much of the remaining discussion focuses upon these unique microshonkinite dikes.

Incompatible element abundances and ultrapotassic character

The representative composition presented in Table 2 emphasizes the exceptional enrichment in many incompatible elements characteristic of the primary microshonkinite at MP. This level of 
Table 2. Chemical analysis of representative primary phlogopite microshonkinite dike (sample MP14), Mountain Pass, California $\{1\}$.

\begin{tabular}{|c|c|c|c|}
\hline $\mathrm{SiO}_{2}$ & 53.9 & $\mathrm{Ba}$ & 8490 \\
\hline $\mathrm{Al}_{2} \mathrm{O}_{3}$ & 10.9 & $\mathrm{Sr}$ & 1230 \\
\hline $\mathrm{Fe}_{2} \mathrm{O}_{3}$ * & 6.43 & Th & 167 \\
\hline $\mathrm{MgO}$ & 8.64 & $U$ & 15.4 \\
\hline $\mathrm{CaO}$ & 6.58 & Th/U & 10.8 \\
\hline $\mathrm{Na}_{2} \mathrm{O}$ & 1.11 & $\mathrm{Zr}$ & 1040 \\
\hline $\mathrm{K}_{2} \mathrm{O}$ & 7.73 & $\mathrm{Hf}$ & 24.9 \\
\hline $\mathrm{BaO}$ & 0.95 & $\mathrm{Zr} / \mathrm{Hf}$ & 42 \\
\hline $\mathrm{P}_{2} \mathrm{O}_{5}$ & 1.70 & $\mathrm{Nb}$ & 28 \\
\hline $\mathrm{TiO}_{2}$ & 1.35 & $\mathrm{Ta}$ & 1.78 \\
\hline $\mathrm{Ln}_{2} \mathrm{O}_{3}$ & 0.26 & $\mathrm{Nb} / \mathrm{Ta}$ & 16 \\
\hline $\mathrm{MnO}$ & 0.12 & \multicolumn{2}{|c|}{ Rare earth elements } \\
\hline $\mathrm{F}$ & 0.969 & $\mathrm{La}$ & 476 \\
\hline $\mathrm{H}_{2} \mathrm{O}$ & 0.80 & $\mathrm{Ce}$ & 1050 \\
\hline $\mathrm{CO}_{2}$ & $\underline{0.04}$ & $\operatorname{Pr}\{7\}$ & 110 \\
\hline$\Sigma\{3\}$ & 101. & $\mathrm{Nd}$ & 470 \\
\hline$m g\{4\}$ & 0.77 & $\mathrm{Sm}$ & 71.0 \\
\hline $\mathrm{K}_{2} \mathrm{O} / \mathrm{Na}_{2} \mathrm{O}$ & 7.0 & $\mathrm{Eu}$ & 13.4 \\
\hline \multirow{2}{*}{ AlkSI $\{5\}$} & 1.00 & $\mathrm{Gd}$ & 35.5 \\
\hline & & $\mathrm{Tb}$ & 3.32 \\
\hline $\mathrm{Cr}$ & 453 & $\mathrm{Yb}$ & 2.28 \\
\hline $\mathrm{Ni}$ & 343 & Lu & 0.293 \\
\hline $\mathrm{Rb}$ & 368 & $\mathrm{Y}$ & 45 \\
\hline Cs & 3.78 & $(\mathrm{La} / \mathrm{Yb})_{\mathrm{cn}}$ & 140 \\
\hline $\mathrm{Rb} / \mathrm{Cs}$ & 97 & & \\
\hline
\end{tabular}

$\{1\}$ Major and minor element oxides $\left(\mathrm{SiO}_{2}-\mathrm{CO}_{2}\right)$ and $\mathrm{F}$, weight percent $(\mathrm{g} / 100 \mathrm{~g})$; minor and trace elements $(\mathrm{Cr}-\mathrm{Y}), \mu \mathrm{g} / \mathrm{g}(\mathrm{ppm})$. Oxides, elements, and ratios whose values are notably elevated are highlighted in bold.

$\{2\} \quad \mathrm{Ln}_{2} \mathrm{O}_{3}=\mathrm{La}_{2} \mathrm{O}_{3}+\mathrm{Ce}_{2} \mathrm{O}_{3}+\mathrm{Pr}_{2} \mathrm{O}_{3}+\mathrm{Nd}_{2} \mathrm{O}_{3}+\mathrm{Sm}_{2} \mathrm{O}_{3}$.

\{3\} Includes $\mathrm{SrO}$ and $-\mathrm{O}=\mathrm{F}$.

\{4\} $m g=\mathrm{MgO} /(\mathrm{MgO}+\mathrm{FeO})$, molar; with weight percent $\mathrm{Fe}_{2} \mathrm{O}_{3} /\left(\mathrm{Fe}_{2} \mathrm{O}_{3}+\mathrm{FeO}\right)$ set to 0.2 .

\{5\} Alkali saturation index: AlkSI = $\left(\mathrm{Na}_{2} \mathrm{O}+\mathrm{K}_{2} \mathrm{O}+\mathrm{BaO}\right) / \mathrm{Al}_{2} \mathrm{O}_{3}$, molar; metaluminous, AlkSI < 1.0; peralkaline, AlkSI > 1.0.

$\{6\}$ Lanthanides determined by INAA (Table 4); $Y$ by EDXRF. 
\{7\} Pr, not measured, is estimated by logarithmic interpolation between $\mathrm{Ce}$ and $\mathrm{Nd}$ : $\mathrm{Pr}$.

$0.157 \sqrt{ }(\mathrm{Ce} \times \mathrm{Nd})$, all values in $\mu \mathrm{g} / \mathrm{g}$.

\{8\} cn: chondrite-normalized (Table 1; Nakamura, 1974); $(\mathrm{La} / \mathrm{Yb})_{\mathrm{cn}}=(\mathrm{La} / \mathrm{Yb}) 30.669$

$\mathrm{Ba}, 8500 \mu \mathrm{g} / \mathrm{g}$, is remarkable for a mafic rock, even an alkaline mafic rock (Fig. 6 ). Concentrations of the other large-ion-lithophile elements - K, $\mathrm{Rb}$, and $\mathrm{Cs}-$ also are remarkably high. The abundance of Th is several to many times higher than typical of other types of alkaline mafic rocks. Concentrations of $F(0.9-$ $1.4 \%$ ) and LREE are among the largest known in unaltered silicate mafic igneous rocks (Figs. 3, 7-9). In this microshonkinite the REE are minor, rather than trace, elements. LREE oxides total about 0.25 percent, and the concentration of $\mathrm{Ce}$ alone is 0.1 percent. These mafic rocks contain more than twice as much total REE as Mn.

Of the several unusual geochemical characteristics of all the MP shonkinites, the most genetically significant is their very high $\mathrm{K}_{2} \mathrm{O} / \mathrm{Na}_{2} \mathrm{O}$. The vast majority of (unaltered) igneous rocks, ranging from peridotites and basalts to granites and syenites, and including most types of alkaline rocks, have weight percent $\mathrm{K}_{2} \mathrm{O} / \mathrm{Na}_{2} \mathrm{O} \leq 1.4$; virtually all have $\mathrm{K}_{2} \mathrm{O} / \mathrm{Na}_{2} \mathrm{O}<3.0$ (Bergman, 1987).

Ultrapotassic rocks are defined as those with $\mathrm{K}_{2} \mathrm{O} / \mathrm{Na}_{2} \mathrm{O}>4.5\left(\right.$ molar $\mathrm{K}_{2} \mathrm{O} / \mathrm{Na}_{2} \mathrm{O}$ $>3.0$ ). Ultra-potassic rocks constitute only a minute fraction of igneous rocks on Earth, in terms of either volume or frequency of occurrence. At MP, the primary microshonkinites are ultrapotassic

(Fig. 6), with median $\mathrm{K}_{2} \mathrm{O} / \mathrm{Na}_{2} \mathrm{O}=5.6$. So too are most of the other shonkinite dikes, and most

of the samples from the shonkinite stocks.

Petrogenesis, by analogy with lamproites

Three suites of fundamentally ultrapotassic igneous rocks are widely recognized: plagioleucitites, kamafugites, and lamproites (Foley and others, 1987; Mitchell and Bergman, 1991; Mitchell, 1996a). Among these, MP shonkinite is similar only to lamproites (Fig. 11; Haxel, in press 1). Lamproites represent very rare, very small volume magmas that are restricted to Archean cratons and their margins. Lamproites are known from only about 25 localities worldwide, and their total volume is $<100 \mathrm{~km}^{3}$ (less than that of some single large basaltic or andesitic stratovolcanos). Type localities for these very rare rocks are Leucite Hills, Wyoming and West Kimberley, Australia. A few lamproites carry traces of xenocrystic diamond.

Although the compositional resemblance between the primary microshonkinite at MP and lamproites is strong, there are a few minor but not insignificant differences (Table 3; Haxel, 1998, in press 1). Therefore, MP shonkinite must be considered lamproite-like, rather than lamproite sensu stricto. Nonetheless, MP shonkinite exhibits most of the distinctive and essential major and trace element 
geochemical features of lamproites, and more closely resembles lamproites than it does any other widely recognized suite of igneous rocks.

Lamproites are generated by partial melting of geochemically exceptional mantle, typically in the thick lithospheric keel beneath Archean cratons (Mitchell and Bergman, 1991). The mantle source material, originally fertile lherzolite, underwent major loss of $\mathrm{Al}, \mathrm{Ca}$, and $\mathrm{Na}$ during Archean extraction of basaltic melt and formation of the overlying continental crust, leaving a depleted harzburgitic residuum. This depleted peridotite subsequently was infiltrated by and reacted with magmas or aqueous fluids that produced vein and metasomatic minerals such as phlogopite, alkali amphibole, clinopyroxene, titanates, and apatite; and introduced incompatible elements, particularly $\mathrm{K}, \mathrm{Ba}$, $\mathrm{Ti}, \mathrm{Zr}, \mathrm{P}$, and LREE. Localized small-degree partial melting of this re-enriched peridotite generates lamproites. The major elements of the lamproite melt come largely from the harzburgite component of the source rock, whereas the incompatible elements whose high abundances characterize the lamproite magma are derived from melting or decomposition of the vein and metasomatic minerals. The rarity of lamproites indicates that melting is very infrequent, that such melts very seldom reach the upper crust, or both.

Table 3. Summary comparison of primary phlogopite microshonkinite at Mountain Pass (MS) and phlogopite lamproites (PL) (as summarized by Bergman, 1987, especially Fig. 20; Mitchell and Bergman, 1991, especially p. 35-38).

Similarities

MS and PL are characterized by abundant phlogopite, both phenocryst and groundmass, and abundant alkali feldspar.

MS and PL are ultrapotassic (Fig. 6).

MS and PL are characterized by extraordinarily high concentrations of:

F (Fig. 7);

Ba (Fig. 6); and

LREE (Figs. 8, 9).

$\mathrm{MS}$ and $\mathrm{Pl}$ are characterized by depletion, relative to basaltic rocks, in $\mathrm{Al}$ and $\mathrm{Ca}$

(Fig. 11A), and $\mathrm{Na}\{1\}$.

$\mathrm{MS}$ and $\mathrm{PL}$ have similar contents of $\mathrm{SiO}_{2}$, total $\mathrm{Fe}$ as $\mathrm{FeO}, \mathrm{CaO}$ (Fig. 11), $\mathrm{Na}_{2} \mathrm{O}$

$\{1\}$, and $\mathrm{Rb}$.

MS and PL have similar contents of $\mathrm{P}_{2} \mathrm{O}_{5}$, and both contain abundant accessory apatite.

MS and PL include primary, mantle-derived rocks with high $\mathrm{MgO}, m g, \mathrm{Ni}$, and $\mathrm{Cr}$

(Fig. 10).

Several minerals diagnostically absent from PL — including nepheline, kalsilite, melilite, and monticellite - also are lacking in MS.

Essential differences

Some MS samples contain accessory plagioclase or quartz; PL do not. Many PL are more strongly peralkaline than MS. 
MS is less strongly depleted in Al than many PL (Fig. 11).

A minority of $\mathrm{PL}$ are perpotassic (molar $\mathrm{K}_{2} \mathrm{O} / \mathrm{Al}_{2} \mathrm{O}_{3}>1$ ); $\mathrm{MS}$ is not (molar $\mathrm{K}_{2} \mathrm{O} / \mathrm{Al}_{2} \mathrm{O}_{3}$. 0.8).

MS has substantially lower concentration of $\mathrm{Ti}$ and $\mathrm{Zr}$ than many $\mathrm{PL}$, and therefore lacks perovskite and the exotic Ti- and $\mathrm{Zr}$-minerals (such as priderite and wadeite) that characterize classic PL.

MP has lower Nb than nearly all PL; and lower Sr than most PL.

Incidental differences

MS is plutonic; most PL are volcanic or hypabyssal.

Leucite is common in PL but absent in MS $\{2\}$.

Though ultrapotassic, MS is less strongly so than some PL $\{3\}$.

MS has even higher LREE and middle REE (such as Sm) than most PL (Figs. 8, 9).

MS has considerably higher Th and Cs than all but a few PL.

\{1\} Arithmetic mean $\mathrm{Na}_{2} \mathrm{O}$ (weight percent): MS, 1.3; PL, 1.4 (Bergman, 1987); basalt, 2.9 (LeMaitre, 1976); alkali basalt, 3.3 (Bergman, 1987).

\{2\} Probably, MS lacks leucite simply because the magma crystallized at plutonic depth, under high vapor pressure (Hatch and others, 1972; Mitchell and Bergman, 1991; Deer and others, 1992; Mitchell, 1996c).

\{3\} Arithmetic mean $\mathrm{K}_{2} \mathrm{O} / \mathrm{Na}_{2} \mathrm{O}$ for $\mathrm{PL}, \approx 11$ (Fig. 6A), is inflated by a minority of samples with $\mathrm{K}_{2} \mathrm{O} / \mathrm{Na}_{2} \mathrm{O}$ as high as $40-100$ (Bergman, 1987). Modal $\mathrm{K}_{2} \mathrm{O} / \mathrm{Na}_{2} \mathrm{O}$ for $\mathrm{PL}$ is substantially lower, $\approx 5$, quite similar to average $\mathrm{K}_{2} \mathrm{O} / \mathrm{Na}_{2} \mathrm{O}$ for MS (Fig. 6B). 
Interestingly, two or three billion years typically elapses between formation of subcontinental lithospheric mantle and lamproite genesis therein. Seemingly, the lithospheric keel must age or mature before it can or does melt to generate lamproites.

The distinctive geochemistry of the primary microshonkinite at MP indicates that its petrogenesis must be closely analogous to that of the better-known lamproite suite (Haxel, in press 1; see also Gleason and others, 1994). In particular, in both lamproites and MP microshonkinite the high concentrations of $\mathrm{K}, \mathrm{F}$, and $\mathrm{Ba}$ require that phlogopite is a major constituent of the mantle source (Fig. 7). Following this reasoning, abundances of incompatible trace elements in MP shonkinite can be successfully modeled by a very small degree $(\sim 0.01-0.1$ $\%)$ of batch partial melting of highly enriched ( 10-40 times chondritic or primitive-mantle) lithospheric mantle. This model suggests that the MP shonkinites are rare or unique rocks because their genesis required the conjunction of two circumstances, both quite rare: existence of exceptionally highly enriched mantle, and ascent of a very-small-volume mantle melt into the upper crust. Most mantle melts of such small volume migrate only a short distance from their source and then refreeze in the mantle (McKenzie, 1985). Ascent of shonkinite magma undoubtedly was facilitated by its high volatile content.

Rare earth element systematics

REE systematics of the primary microshonkinite at MP further emphasize its singular geochemistry (Fig. 3), and its affinity to the LREE-rich MP carbonatite. Among all widely recognized suites of silicate igneous rocks, lamproites have the highest concentrations of total REE and the highest degrees of LREE-HREE fractionation (that is, the highest La/Yb ratios) (Cullers and Graf, 1984; Mitchell and Bergman, 1991). In considering lamproites, I concentrate upon phlogopite lamproites, as this class includes the primary members of the lamproite suite, as well as many other primitive or near-primitive compositions; and de-emphasize olivine lamproites, which are non-primary, derivative, hybrid rocks (Mitchell and Bergman, 1991, p. 399-400).

Remarkably, the primary microshonkinite at MP displays even higher concentration of LREE and middle REE than most phlogopite lamproites. In Figure 8, REE spectra of the microshonkinite samples lie along or slightly above the upper part of the range for phlogopite lamproites from several classic provinces. The microshonkinite also has slightly greater REE fractionation than most phlogopite lamproites: $(\mathrm{La} / \mathrm{Yb})_{\mathrm{cn}} .135$, in contrast to the phlogopite lamproite mean of about 95 - 100. Examining these relations in another way, Figure 10 shows that $\mathrm{La} / \mathrm{Yb}$ ratios in the microshonkinite overlap with the upper part of the range for phlogopite lamproite, but the microshonkinite is unsurpassed in its concentrations of Sm (representing the middle REE). 
Mountain Pass Carbonatite

Petrology and geochemistry

Figure 12 is a photograph of an exceedingly strange igneous rock - a porphyritic carbonatite from Mountain Pass. The medium-grained groundmass, mostly calcite, surrounds centimeter-size phenocrysts of barite(!). The chemical composition of this strange rock, a sövite, is illustrated in Figure 13 and Table 4. Oxides of $\mathrm{Ca}$ and $\mathrm{Ba}$ together make up nearly one-half of the rock. Oxides of $\mathrm{C}$ and $\mathrm{S}$ make most of the remainder. All of the normal rock-forming oxides except $\mathrm{CaO}\left(\mathrm{SiO}_{2}, \mathrm{Al}_{2} \mathrm{O}_{3}, \ldots, \mathrm{H}_{2} \mathrm{O}\right)$ combined constitute only about two percent. The whole-rock content of REE oxides exceeds 10 percent!

Table 4. INAA analysis of bastnäsite-barite sövite (sample GH2-57), Mountain Pass, California $\{1\}$.

\begin{tabular}{|c|c|c|c|c|c|}
\hline $\mathrm{La}$ & 2.92 & $\%$ & $\mathrm{Ba}$ & 12.7 & $\%$ \\
\hline $\mathrm{Ce}$ & 5.28 & "\% & $\mathrm{Sr}$ & 0.466 & $\%$ \\
\hline $\operatorname{Pr}\{3\}$ & 0.39 & $\%$ & $\mathrm{Rb}$ & 26.2 & $\mu \mathrm{g} / \mathrm{g}$ \\
\hline $\mathrm{Nd}$ & 1.15 & $\%$ & Cs & 0.24 & $\mu \mathrm{g} / \mathrm{g}$ \\
\hline $\mathrm{Sm}$ & 643 & $\mu \mathrm{g} / \mathrm{g}$ & $\mathrm{Rb} / \mathrm{Cs}$ & 109 & \\
\hline $\mathrm{Eu}$ & 114 & $\mu \mathrm{g} / \mathrm{g}$ & $\operatorname{Ti}\{5\}$ & 900 & $\mu \mathrm{g} / \mathrm{g}$ \\
\hline $\mathrm{Gd}$ & 220 & $\mu \mathrm{g} / \mathrm{g}$ & $P\{5\}$ & 1600 & $\mu \mathrm{g} / \mathrm{g}$ \\
\hline $\mathrm{Tb}$ & 14.3 & $\mu \mathrm{g} / \mathrm{g}$ & $\mathrm{Zr}$ & 1020 & $\mu \mathrm{g} / \mathrm{g}$ \\
\hline $\mathrm{Ho}$ & 4.34 & $\mu \mathrm{g} / \mathrm{g}$ & $\mathrm{Hf}$ & 3.64 & $\mu \mathrm{g} / \mathrm{g}$ \\
\hline $\mathrm{Tm}$ & 0.918 & $\mu \mathrm{g} / \mathrm{g}$ & $\mathrm{Zr} / \mathrm{Hf}$ & 280 & \\
\hline $\mathrm{Yb}$ & 4.76 & $\mu \mathrm{g} / \mathrm{g}$ & $\mathrm{Nb}\{5\}$ & 57 & $\mu \mathrm{g} / \mathrm{g}$ \\
\hline Lu & 0.673 & $\mu \mathrm{g} / \mathrm{g}$ & $\mathrm{Ta}$ & 0.515 & $\mu \mathrm{g} / \mathrm{g}$ \\
\hline$\sum \operatorname{Ln}$ & 9.85 & $\%$ & $\mathrm{Nb} / \mathrm{Ta}$ & 110 & \\
\hline $\mathrm{Ln}_{2} \mathrm{O}_{3}$ & 11.5 & $\%$ & Th & 181 & $\mu \mathrm{g} / \mathrm{g}$ \\
\hline$(\mathrm{La} / \mathrm{Yb})_{\mathrm{cn}}$ & 4100 & & $U\{5\}$ & 19.1 & $\mu \mathrm{g} / \mathrm{g}$ \\
\hline$\dot{\mathrm{F}}=\{5\}$ & 1.30 & $\%$ & Th/U & 9.5 & \\
\hline \multicolumn{6}{|c|}{ 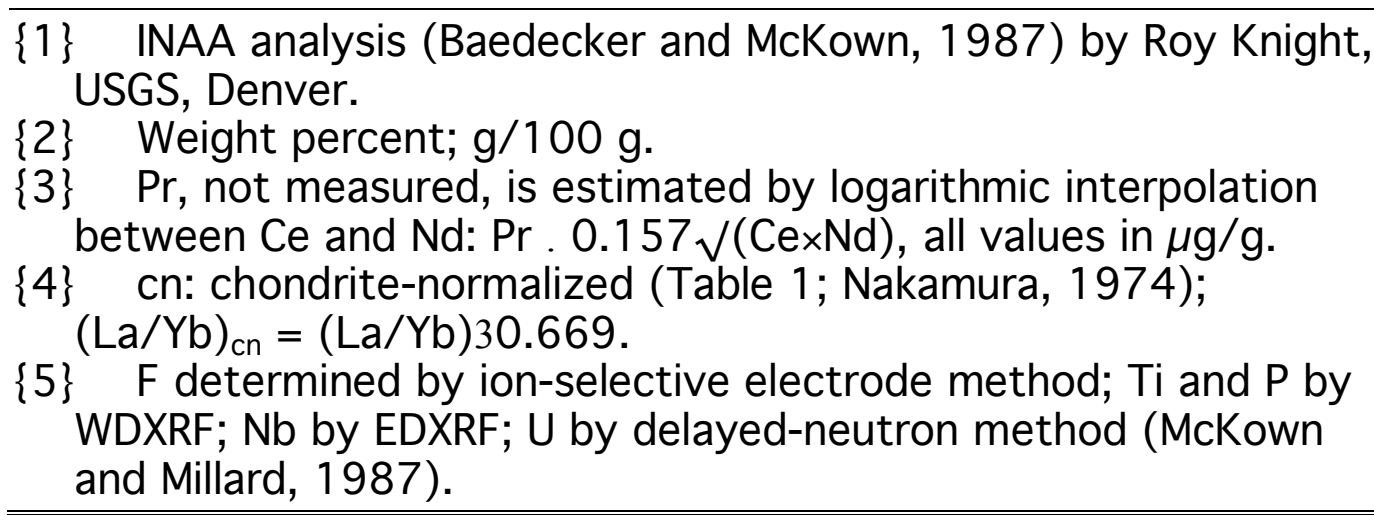 } \\
\hline
\end{tabular}

Within the MP district, carbonatite forms dozens of widely scattered dikes and a single larger intrusion, the Sulfide Queen stock (Fig. 5). Some of the smaller 
carbonate bodies probably are veins rather than dikes (though this distinction may be in part semantic).

The Sulfide Queen carbonatite stock has a north-south strike length of about $700 \mathrm{~m}$, is roughly $70 \mathrm{~m}$ thick, and dips about $40^{\circ}$ west (Barnum, 1989). Olson and others (1954) mapped three intergradational units: ferruginous dolomite carbonatite (beforsite), barite-calcite carbonatite (sövite), and silicified carbonatite. The most abundant type, sövite, consists of 40 to 75 volume percent calcite, 15 - 50 percent barite, and 5 - 15 percent bastnäsite (Fig. 12). Bastnäsite, the chief REE ore mineral at MP, has the formula $(\mathrm{Ce}, \mathrm{La}, \mathrm{Nd}, \mathrm{Pr})\left(\mathrm{CO}_{3}\right) \mathrm{F}$. In some places it is accompanied by parisite, $\mathrm{CaCe}_{2}\left(\mathrm{CO}_{3}\right)_{3} \mathrm{~F}_{2}$ (where Ce represent the LREE), which can be thought of as two moles of bastnäsite plus one mole of calcite. Accessory minerals in the carbonatite, some uncommon or sporadic in distribution, include other bastnäsite-family REE fluorocarbonate and carbonate phases (Jaffe and others, 1953; Williams-Jones and Wood, 1992), strontianite, celestite, phlogopite, apatite, monazite, thorite, allanite, chlorite, zircon, pyrite, galena, magnetite, and hematite.

The MP carbonatite is "[0]ne of the most unusual of all carbonatites ..." (Heinrich, 1966; Olson and others, 1954; Mariano, 1989a, 1989b):

- The MP carbonatite is closely associated with saturated to oversaturated (in $\mathrm{SiO}_{2}$ ), phlogopite-rich, ultrapotassic silicate igneous rocks, whereas nearly all other carbonatites

are associated with undersaturated, nephelinitic, sodic rocks.

- Ca-silicate minerals common in many carbonatites, such as garnet and monticellite, are absent at MP.

- Unlike most, the MP carbonatite is not significantly enriched in the highfield-strength elements $\mathrm{P}, \mathrm{Ti}$, and $\mathrm{Nb}$. Apatite and monazite, abundant in other carbonatites, are conspicuously sparse. Ti-Nb phases, such as pyrochlore or perovskite, are absent.

- Concentrations of Ba and LREE are extremely high (Table 4; Figs. 3, 14, 15); correspondingly, barite and bastnäsite are unusually abundant.

- Bastnäsite is magmatic, rather than hydrothermal as in most other carbonatites.

Among all terrestrial igneous rocks, carbonatites have the greatest concentrations of LREE and the strongest REE fractionation: typically La 200 - $5000 \mu \mathrm{g} / \mathrm{g}$ and $(\mathrm{La} / \mathrm{Yb})_{\mathrm{cn}} \sim 100$ - 1000 (Cullers and Graf, 1984; Woolley and Kempe, 1989). Even in comparison with other carbon-atites, the LREE enrichment and REE fractionation of MP carbonatite are extraordinary: La = $7000-51,000 \mu \mathrm{g} / \mathrm{g}$ (median $26,000 \mu \mathrm{g} / \mathrm{g})$ and $(\mathrm{La} / \mathrm{Yb})_{\mathrm{cn}}=700-6600$ (median 3600) (Figs. 3, 15). While the MP carbonatite is best known for its concentration of LREE, its enrichment is Ba is just as extraordinary. Median content of $\mathrm{Ba}$ is 14 percent, $100-1000$ times greater than most other carbonatites (Figs. 14, 15). Thus, MP sövite is compositionally extreme even for a carbonatite. 
Figures 3 and $12-15$ and Table 4 should amply substantiate the statement made in the introduction that the Mountain Pass carbonatite is one of the most bizarre igneous rocks on Earth.

Origin

Its field relations and extraordinary composition leave no doubt as to the igneous nature of the MP carbonatite. Although Olson and others (1954, p. 5963) conservatively referred to the carbonatite as "carbonate rock", they clearly recognized its igneous character, based upon regional geology, field relations, petrologic evidence, and rudimentary geochemical data. All subsequent workers have accepted the carbonatite as an intrusive igneous rock. Experiments conducted by Wyllie and others (1996; Wyllie, 1989) further support an igneous origin: "... addition of water to the Mountain Pass carbonatite is all that is required for it to be molten at approximately $543^{\circ} \mathrm{C}$ and 1 kbar pressure.". These experiments also are entirely consistent with the magmatic origin of bastnäsite in the MP carbonatite.

Available data do not permit a full account of the origin of MP carbonatite. I can offer only a few preliminary ideas, and a concluding speculation. Three related issues need to be considered: genetic relations of carbonatite and ultrapotassic silicate magmas, presumed mantle genesis of the carbonatite, and the extraordinary enrichment of LREE and $\mathrm{Ba}$ in the carbonatite.

Two lines of evidence indicate the independence of carbonate and silicate magmas at MP. First, field relations (Olson and others, 1954) show that the two magmas arrived in the upper crust separately. Second, the Sulfide Queen carbonatite is approximately 25 m.y. younger than the main shonkinite and syenite (U-Th-Pb and Ar-Ar ages: DeWitt and others, 1987). These data seem to preclude any scenario in which carbonatite magma at MP is derived directly from ultrapotassic silicate magma.

The MP carbonatite magma seemingly can have originated only in the mantle. Continental crust contains no known reservoir capable of yielding carbonatite magma. On the other hand, melting of carbonate-bearing peridotite in the mantle to produce carbonatite is well documented (Gittins, 1989; Wyllie and others, 1996), and carbonatites are routinely studied as samples of the mantle (Nelson and others, 1988; Bell and Tilton, 2002). The Sr isotopic composition of the MP carbonatite $\left(\left[{ }^{87} \mathrm{Sr} /{ }^{86} \mathrm{Sr}\right]_{\text {initial }}=0.7044, \varepsilon_{\mathrm{Sr}}=22\right.$; Powell and others, 1966), though slightly more radiogenic than most carbonatites (Bell and Blenkinsop, 1989), is consistent with mantle genesis. The origin of the MP carbonatite can be examined in greater detail when unpublished isotopic data (DeWitt and others, 1987; personal communication, 2003) become available.

The extraordinary levels of LREE and Ba could owe to either or both of two factors: a very highly enriched mantle source, or concentration of these elements through prolonged crystal fractionation. Two kinds of evidence favor an unusual mantle source as the most important contributor. First, no much larger body of precursor carbonatite with much lower LREE and Ba than the Sulfide Queen stock is known at MP (Olson and others, 1954; Barnum, 1989; 
Wyllie and others, 1996). Second, several of the most distinctive and important characteristics of the carbonatite - high LREE, Ba, and F - are shared by the mantle-derived primary micro-shonkinite. The geochemical affinity of these two very unusual magmas, occurring together in the same small district, surely is no coincidence. I suggest that both originated by melting within the same area or zone of highly anomalous upper mantle, in two successive and closely related episodes.

This hypothesis requires or implies (1) a mantle source highly enriched in LREE, (2) transport of high concentrations of LREE in a carbonatite melt, and (3) retention of LREE as the magma ascended to the upper crust.

(1) The exceptional abundance of LREE in the primary microshonkinite independently indicates a mantle source rich in LREE. In enriched mantle LREE (and $\mathrm{Ba}$ ) can reside in titanate minerals of the crichtonite group, $A(\mathrm{Ti}, \mathrm{Fe}, \mathrm{Cr})_{21} \mathrm{O}_{38}$, where $A$ can include $\mathrm{Ca}, \mathrm{Ba}$, LREE, $\mathrm{Sr}, \mathrm{K}$, and others (Jones and Ekambaram, 1985; Jones, 1989).

(2) Experiments with carbonate melts have established the very high solubility of LREE, 20 - 40 percent, so natural carbonatite magmas are considered efficient scavengers of LREE (Wyllie, 1989; Wyllie and others, 1996). Fluorine may play an important role in the transport of REE by carbonatite magma (Gittins, 1989).

(3) Retention of LREE in the magma until it ascended to the upper crust evidently is related to the very high $\mathrm{F} / \mathrm{P}$ ratio of the MP carbonatite (Table 4), as indicated by the unusual abundance of bastnäsite and paucity of monazite and apatite relative to other carbonatites (Mariano, 1986b; Wyllie and others, 1996). Low $P$ content inhibited early precipitation of monazite and apatite, so LREE remained in solution. High concentration of $F$ then allowed most of the endowment of LREE to crystallize as magmatic bastnäsite and parisite.

Fluorine in the carbonatite magma presumably derives from phlogopite in the enriched mantle that sourced the primary microshonkinite magma. This phlogopite evidently was unusually rich in fluorine. Thus, I speculate that the remarkable silicate and carbonate igneous rocks at Mountain Pass fundamentally reflect a localized fluorine anomaly in the underlying lithospheric mantle.

Rare Earth Element Deposit and Mine

Ore

Mountain Pass is a magmatic ore deposit; the Sulfide Queen carbonatite stock is the ore body. This is the only major ore deposit in the world mined solely for its REE content. Ore grades at MP are as high as 15 percent REE oxides (REO) (Barnum, 1989; Castor, 1990, 1991, 1994; Kilbourn, 1993a). Average grade is 8.5 - 9 percent; cutoff grade is 5 percent. Protore grading $2-5$ percent REO is stockpiled. For processing, different types of carbonatite ore are blended to achieve a uniform starting grade of 8.5 percent. Stated reserves at MP are $* 20$ million metric tons, at 5 percent cutoff grade. 
Typical MP REE ore consists of about 65 volume percent calcite and/or dolomite; 20 - 25 percent barite, celestite, and strontianite; and $10-15$ percent bastnäsite, the ore mineral. Bastnäsite is in several ways an ideal REE ore mineral. It constitutes a substantial fraction of the ore, and its REE content approaches the theoretical proportion, 64 percent elemental REE (75\% REO). Bastnäsite is more easily decomposed than most silicate or phosphate minerals. Furthermore, bastnäsite has lower concentrations of weakly radioactive Th and its highly radioactive intermediate daughter products (particularly $\mathrm{Ra}$ ) than the second most important REE ore mineral, monazite. Though a minor phase at MP, monazite is or has been a major REE ore mineral elsewhere in the world.

Rare earth element geochemistry

Concentrations of the individual REE in MP ore represent the superposition of two factors, one nuclear and one geochemical and mineralogical. First, the fundamental baseline for terrestrial geochemical processes is the cosmic abundances of the REE established during pre-Solar System nucleosynthesis (Sneden and Cowan, 2003; Cowan and Thielemann, 2004). REE with even atomic numbers $\left({ }_{58} \mathrm{Ce},{ }_{60} \mathrm{Nd}, \ldots\right)$ have $\sim 3-10$ times greater cosmic and terrestrial abundances than adjacent REE with odd atomic numbers $\left({ }_{57} \mathrm{La},{ }_{59} \mathrm{Pr}\right.$, ...) (Fig. 16A). This fact is a consequence of nuclear physics, transcending chemistry or geochemistry. The even-odd alternation of primordial abundances is reflected, imperfectly, in the relative prices of the individual REE (Fig. 16B; Haxel and others, 2002, Fig. 3).

Second, MP bastnäsite is characterized by extreme preferential enrichment in LREE relative to HREE: $\mathrm{La}_{\mathrm{cn}} \cdot 6.6 \bullet 10^{5}, \mathrm{Yb}_{\mathrm{cn}}$. 20, and $(\mathrm{La} / \mathrm{Yb})_{\mathrm{cn}}$. 37,000 (Table 4; Fig. 17; Fleischer, 1978; Johnson and Sisneros, 1982; Mariano, 1989b; Kilbourn, 1993a). Some perspective on these values can be gained by comparison with average upper continental crust (Table 1). In MP bastnäsite $\mathrm{Yb}$ is enriched over average upper crust by a factor of 2 , whereas La is enriched by a factor of 7000 .

Owing to these two factors, Ce alone makes up nearly one-half of the total REE content of MP ore, and La constitutes one-third (Fig. 18). The four lightest REE ( $\mathrm{La}, \mathrm{Ce}, \mathrm{Pr}, \mathrm{Nd}$ ) total almost 99 percent (Table 4). Europium, the most valuable of the REE routinely produced at MP, constitutes only about 0.1 percent of the REE in the ore.

Processing and products

This highly simplified summary of processing steps used at MP (Figs. 19-21) is based chiefly upon Kilbourn (1992, 1993a, 1994), Hedrick and Haxel (in press), and information provided by Brock O'Kelley (written communication, 2005). Specifications for REE products from MP, including many not mentioned here, are available at www.molycorp.com.

Ore is mined from a small open pit, in 2004 about $150 \mathrm{~m}$ deep and $500 \mathrm{~m}$ in diameter. Striping ratio, waste to ore, is about 8:1. Following crushing and 
grinding, bastnäsite is separated from gangue minerals by flotation. The bastnäsite is then routed three ways.

( 1 ) Some is packaged as "bastnäsite concentrate". This product contains $\approx 60$ percent REO, and includes residual gangue minerals.

(2) Some bastnäsite is gently leached with $\mathrm{HCl}$ to partially dissolve carbonate gangue minerals and produce an upgraded material called "leached bastnäsite concentrate", $\approx 70$ percent REO. Some of this is packaged. The remainder is calcined (strongly heated under oxidizing conditions) to decompose bastnäsite and expel $\mathrm{CO}_{2}$ and $\mathrm{H}_{2} \mathrm{O}$, yielding a further upgraded product called "calcined leached bastnäsite", comprising chiefly Ln oxyfluorides in which Ce has been partially or largely oxidized to $\mathrm{Ce}^{4+}$, and containing $85-90$ percent REO. Although "leached bastnäsite concentrate" and "calcined leached bastnäsite" have progressively higher concentrations of REO, individual lanthanides are still present in the same proportions as in the original ore (Fig. 18).

(3) Bastnäsite concentrate, either previously leached or unleached, may be roasted in a multiple hearth furnace, then leached with dilute $\mathrm{HCl}$. These steps decompose bastnäsite, oxidize $\mathrm{Ce}$, and further remove gangue materials. Leaching yields two fractions: Ce-enriched residue and Ce-depleted $\mathrm{LnCl}_{3}$ solution. Some of the $\mathrm{Ce}$ residue is packaged as $\mathrm{Ce}$ concentrate, composed chiefly of $\mathrm{CeO}_{2}$ and Ce-Ln oxyfluoride, approximately $\left(\mathrm{Ce}^{4+}, \mathrm{Ln}^{3+}\right)\left(\mathrm{O}_{2}, \mathrm{OF}\right)$. Cerium concentrate is the first product in which the original (ore-body) proportions of the individual lanthanides have been significantly modified. Cerium has been upgraded from \& 50 percent to $* 85$ percent of total lanthanides (Figs. 18, 20). The remainder of the Ce residue is passed to a separate plant that produces high-purity (96 - $99 \%$ ) ceric oxide and cerous carbonate and nitrate.

Depending on the desired products, the $\mathrm{LnCl}_{3}$ solution may be packed as such or may undergo further processing to make several other materials. Lanthanide compounds can be precipitated from this solution by reacting it with an alkali or basic salt. For example, reaction with $\mathrm{NaOH}$ yields a precipitate of La-Ln concentrate, approximate composition $(\mathrm{La}, \mathrm{Ln})(\mathrm{OH})_{2.5} \mathrm{Cl}_{0.5}$. Or, reaction with $\mathrm{NaCO}_{3}$ produces La-Ln carbonate. In these three products La constitutes $\approx 58$ 64 percent of total lanthanides, and Ce only $6-15$ percent.

Because the separation of Ce-enriched residue and $\mathrm{LnCl}_{3}$ solution is imperfect, a small amount of Ce is leached into the $\mathrm{LnCl}_{3}$ solution. Some of this solution may be routed to a redox unit where $\mathrm{Ce}$ is preferentially separated and precipitated as cerous carbonate, in which Ce constitutes at least 96 percent of total lanthanides.

The $\mathrm{LnCl}_{3}$ solution also serves as feedstock for the solvent extraction plants, where $\mathrm{La}, \mathrm{Pr}, \mathrm{Nd}, \mathrm{Sm}$, Eu, and $\mathrm{Gd}$ are separated and purified. Solvent extraction involves differential partitioning of individual lanthanides between two immiscible liquid phases, one aqueous and one organic

(Fig. 21; Harrah, 1967; Kilbourn, 1994; Sabot and Maestro, 1995). Solvent extraction is a Rayleigh fractionation process, analogous to perfect fractional crystallization, familiar in igneous petrology (Gast, 1968). Purity of lanthanide 
oxides produced by solvent extraction at MP ranges from 96 to 99.995 percent. Further purification may be undertaken by the customer.

Among the numerous high-technology products available from the solvent extraction plant at MP is $\mathrm{Y}$-Eu coprecipitate, $\left(\mathrm{Y}_{0.96}, \mathrm{Eu}_{0.04}\right)_{2} \mathrm{O}_{3}$, used as a phosphor. This compound contains . 6 weight percent $\mathrm{Eu}_{2} \mathrm{O}_{3}$ but no more than $10 \mu \mathrm{g} / \mathrm{g} \mathrm{Sm}_{2} \mathrm{O}_{3}, 2 \mu \mathrm{g} / \mathrm{g} \mathrm{Nd}_{2} \mathrm{O}_{3}$, and $1 \mu \mathrm{g} / \mathrm{g}$ of any other $\mathrm{Ln}_{2} \mathrm{O}_{3}$.

History

Bastnäsite was discovered in a carbonatite dike at the Birthday locality in 1949, and the Sulfide Queen carbonatite stock discovered and recognized as a major REE deposit in 1950 (Anonymous, 1952; Hewett, 1954). Molycorp acquired the deposit and began mining in the early 1950s. Initially the chief product was mischmetal, an alloy of unseparated and unfractionated LREE metals, prepared by electrolytic reduction of molten $\mathrm{LnCl}_{3}$. Mischmetal, which is pyrophoric owing to its high Ce content, is used to make lighter flints. These were an important consumer product in an era when smoking was prevalent. Michmetal is also an additive in certain steel alloys, where it sequesters sulfur and oxygen impurities as stable lanthanide oxysulfides. These compounds have more desirable hightemperature mechanical properties than the Fe and Mn sulfides and oxides that would form in the absence of mischmetal additive (Kilbourn, 1992, 1993a, b). Cerium oxide or concentrate used for polishing of glass was (and still is) another major product from MP.

Development at MP accelerated in the 1960s, driven and financed largely by the demand for Eu created by the large-scale commercialization of color television (Evans, 1966). All color cathode-ray tubes utilize Eu in the red phosphor; despite the relative scarcity and high cost of Eu, no practicable substitute has ever been found. A typical television tube contains about $0.2 \mathrm{~g}$ of Eu. At its peak in the 1960s and 1970s, MP produced as much as $40 \mathrm{~kg}$ of Eu per day.

For some thirty years, MP strongly dominated the world's supply of REE, especially LREE and Eu (Castor, 1990; Haxel and others, 2002). Since the mid1980s, Chinese production of REE has grown dramatically. Production from China now considerably exceeds that from MP. Chinese deposits are significantly lower in grade than MP, but some of them are huge. Furthermore, some Chinese deposits have elevated concentrations of the less abundant and more valuable HREE, and Eu (Fig. 16B). Nonetheless, Mountain Pass remains one of several major sources of light rare earth elements, and the only such source in North America.

Operations of the mine and many of the processing facilities at MP were suspended in the late 1990s, following a series of environmental and regulatory problems. At the time of our visit in October 2004, chief activities were production of bastnäsite concentrates from extensive stockpiles accumulated before suspension of mining, sale of some other products from inventory, and preparations for acquisition of permits required to resume full operation. 
Applications of the Rare Earth Elements: An Example

Despite their obscurity, the REE have thousands of technological applications, with dozens or hundreds more discovered or invented each year (Hedrick, 1988, 1995; Kilbourn, 1992, 1993a, 1994; Haxel and others, 2002; Orris and others, in press). Here I summarize just one facet of one type of application the use of REE in high-technology phosphors (Blasse and Grabmaier, 1994; Waychunas, 2002; see also Schubert and Kim, 2005). I have selected this particular example because it illustrates three attributes typical of many REE applications: versatility, specificity, and environmental importance.

The ubiquitous incandescent lamp, an invention more than a century old, is quite inefficient. An ordinary 100 -watt bulb produces $<10 \mathrm{~W}$ of light (visible radiation) but $>90 \mathrm{~W}$ of heat (infrared radiation). This wastefulness, originally justifiable on grounds of simplicity and convenience, becomes extravagant in an era of depletion of hydrocarbon resources, ever increasing energy prices, and global warming related to consumption of fossil fuels. Fluorescent lamps are several times more efficient, hence their widespread use, especially in institutional and commercial settings. However, conventional fluorescent lamps have two major drawbacks. First, reasonable efficiency and optimal color balance are mutually exclusive. Second, mercury-vapor electrical discharge is required to excite fluorescence. Use of mercury has been discontinued in most consumer products because of its high toxicity, but for fluorescent lamps no substitute is yet feasible.

Compared to conventional fluorescent lamps, new tricolor fluorescent lamps utilizing REE phosphors are both considerably more efficient and capable of better color balance (Smets, 1987, 1991; Welker, 1991). In one typical design three phosphors are used, containing four lanthanides and $Y$, in two different oxidation states:
- Red, $\mathrm{Y}_{2} \mathrm{O}_{3}: \mathrm{Eu}^{3+}$
Blue, $\mathrm{Sr}_{5}\left(\mathrm{PO}_{4}\right)_{3} \mathrm{Cl}: \mathrm{Eu}^{2+}$
- Green, (La,Ce)PO 4 :

The conventional notation $\mathrm{Y}_{2} \mathrm{O}_{3}$ :Eu ${ }^{3+}$ (for example) denotes Eu-doped $\mathrm{Y}_{2} \mathrm{O}_{3}$; that is, $\mathrm{Y}_{2} \mathrm{O}_{3}$ in which some $\mathrm{Y}^{3+}$ is substituted by $\mathrm{Eu}^{3+}$. These three phosphors together produce a white light that simulates daylight (Fig. 22A). The red phosphor is similar to that used in color cathode-ray tubes. Note that the green and blue phosphors are compositional analogs of monazite and apatite, respectively. In the green phosphor $\mathrm{Ce}$ is essential as a sensitizer, which efficiently absorbs ultraviolet radiation from the $\mathrm{Hg}$-vapor discharge and permits a lower doping level of expensive Tb. The lamps may also use a fifth lanthanide, artificially created ${ }^{147} \mathrm{Pm}$, a soft-beta emitter with high activity, added in nanogram quantities to provide ionization to facilitate starting. Widespread adoption of these new highly efficient fluorescent lamps would lead to a major reduction in energy consumption for lighting (Reilly, 1991).

Further improvement in fluorescent lamps may eventually be possible through a developing technology called downconversion or quantum cutting (Antia, 1999). The goal is to replace toxic mercury with inert xenon. Xenon is scarce (mass fraction in the atmosphere $0.4 \mu \mathrm{g} / \mathrm{g}$ ) and expensive; widespread use in lamps would 
probably necessitate a program of recycling. But, the atmospheric reservoir is virtually inexhaustible, and any released Xe simply returns to the atmosphere.

In mercury-based lamps, each ultraviolet photon emitted by the Hg vapor ideally causes the phosphor(s) to emit one visible photon. That is, quantum efficiency is at most 100 percent. Ultraviolet photons generated by a Xe discharge have considerably higher energy than those from $\mathrm{Hg}$ vapor, so one-for-one conversion is too inefficient. Xenon-based fluorescent lamps will require phosphors that can generate more than one visible photon from a single ultraviolet photon. Such a downconversion phosphor has recently been demonstrated, utilizing $\mathrm{LiGdF}_{4}$ :Eu (Wegh and others, 1999). Gadolinium absorbs an ultraviolet photon with energy $\approx 6 \mathrm{eV}$ (Fig. 22B). About two-thirds of this energy is transferred, through a complex series of steps, to $\mathrm{Eu}^{3+}$, which emits two photons with energy $\approx 2.0-2.1 \mathrm{eV}$ (wavelength $\approx 585-630 \mathrm{~nm}$ ), in the orange to red portion of the visible spectrum. The quantum efficiency of this phosphor approaches 200 percent. The next steps are to increase energy efficiency and brightness through better ultraviolet absorption, and to develop analogous green and blue phosphors. Although far from mature, downconversion technology epitomizes the futuristic character of many REE applications.

Relations of the Alkaline Igneous Rocks at Mountain Pass to the 1.4 Ga Plutonic Belt

Ultrapotassic to potassic silicate igneous rocks of $1.4 \mathrm{Ga}$ age broadly similar to those at Mountain Pass crop out several other places in the eastern Mojave Desert and surrounding regions (DeWitt and others, 1987; Castor and Gleason, 1989; Castor, 1991; Gleason and others, 1994; Haxel, in press 1). I conclude by outlining possible relations of these ultrapotassic rocks, including those at MP, to the greater 1.4-Ga transcontinental plutonic belt (Anderson, 1989; Castor, 1993; Gleason and others, 1994). Three hypotheses seem worth considering:

(1) Parental magma. The ultrapotassic rocks provide rare samples of the parental magma or a parental magma for 1.4-Ga plutons.

(2) Alkaline end member. The ultrapotassic rocks represent uniquely pure melts of a widespread, highly enriched, subcontinental lithospheric mantle source that contributed, in generally small proportions, to the moderately and variably alkaline 1.4-Ga plutons. This is a refined version of hypothesis 1 .

(3) Localized, incidental melting. The 1.4-Ga thermal event triggered melting of rare, highly localized, geochemically exceptional lithospheric mantle. This small, unique domain within the *1.8-Ga subcontinental mantle of the Southwest was similar to the source material of lamproite, but at $1.4 \mathrm{Ga}$ had not yet aged or matured sufficiently to be capable of generating lamproite. Caught up in the massive 1.4-Ga thermal event, it melted prematurely. The Nd isotopic composition of MP shonkinite (DePaolo and Wasserberg, 1976) is consistent with this scenario. Thus, the ultrapotassic and potassic igneous rocks in the eastern Mojave Desert are indeed a local phenomena, not essentially related to the overall genesis of the 1.4-Ga plutonic belt. 
I currently favor the third hypothesis. Its major advantage is that it accounts for the uniqueness of the Mountain Pass shonkinite and related ultrapotassic rocks. Its principal disadvantage is that much of the story is inconveniently (or conveniently) hidden in the mantle.

Appendix: Field Trip Localities

These field trip localities lie in the northeast quadrant of the Mescal Range 7.59 $(1: 24,000)$ topographic quadrangle (Fig. 23).

Synplutonic dikes

Exit Interstate 15 at Bailey Road (Figs. 4, 23). If eastbound, turn right (south) on Bailey Road and stop. If westbound, turn left, cross southward over the interstate, go past the eastbound entrance and exit ramps, and stop. Reset trip odometer here. Turn left (east) onto an old paved road, marked by an orange sign: "road not maintained by san bernardino co". Continue east on this road; at $\approx 0.6-0.7$ miles it swings right (south) and then becomes a dirt road, known locally as Kokoweef Road. At . 1.1 miles (at a dilapidated corral, marked on the topographic map), the road turns from south to southeast. At . 1.3 miles, turn right (southward) at an oblique angle onto a secondary, mining-district dirt road. UTM coordinates (NAD 1927) of this key intersection are $\{34.848$, 24.746\}. Walk (or drive) $170 \mathrm{~m}$ southward on this secondary road, to the point $(\{34.844,24.576\})$ where the road turns to the right (west) and leaves the arroyo.

Continue walking south-southeastward up the arroyo, for another $120 \mathrm{~m}$ or so, now on outcrops of syenite with shonkinite dikes and derivative inclusions. Watch for rounded boulders of syenite on the right (west) side of the arroyo. Stop to the left (east) of the most prominent of these boulders. Alternatively, stop at the first place where the bottom of the arroyo narrows where it is partially blocked by syenite boulders. The greatest concentration of synplutonic shonkinite dikes within the syenite occurs here - around, east, and northeast of $\{34.907,24.487\}$ (Fig. 23, (1). The area of abundant dikes includes the bottom of the arroyo, the east side of the arroyo, and the west side of the low ridge east of and subparallel to the arroyo. Additional interesting examples of dikes and related inclusions can be seen along this ridge.

This locality features excellent exposures of synplutonic shonkinite dikes within the Tors shonkinite-syenite stock (Fig. 5; Olson and others, 1954; Morton and others, 1991). This composite stock ranges in composition from phlogopite shonkinite (melanosyenite) $\left(\approx 45\right.$ weight $\left.\% \mathrm{SiO}_{2}\right)$ to leucosyenite $\left(\approx 63 \% \mathrm{SiO}_{2}\right)$. The most mafic rocks are phlogopite-rich shonkinite and, locally, phlogopitite; some of these have essential olivine. In the Tors, Wheaton, and Birthday stocks, such rocks contain as much as $14-17$ weight percent MgO. I provisionally interpret these melano-cratic rocks as crystal-rich cumulates. The largest part of the Tors stock is biotite-amphibole mesosyenite. In some places syenite intrudes shonkinite; elsewhere contacts are gradational. The margins of the stock are locally marked by well-developed intrusion breccias. 
The biotite-amphibole mesosyenite of the Tors stock is widely intruded by small ( $0.1-0.5 \mathrm{~m}$ wide) dikes of medium- to coarse-grained phlogopite shonkinite. These synplutonic dikes display an intriguing and informative variety of shapes, patterns, and textures, collectively indicating that shonkinite magma was intruded repeatedly during solidification of the syenite, and that shonkinite mingled and locally mixed with syenite. Early dikes were extensively backintruded and disrupted by their syenite host, so that they now form trains of ovoid to amoeboid shonkinite inclusions within the syenite (Fig. 24A). Later dikes partially or largely maintain their original tabular shapes (Fig. 24B), and locally have fine-grained margins against the host syenite. But, even these younger dikes were locally intruded or veined by syenite or leucosyenite. The youngest shonkinite dikes both crosscut and are crosscut by syenoaplite dikes. One provocative outcrop, in the southeast part of the area $(\{34.994,24.485\})$, indicates that late shonkinitic magma and aplitic magma coexisted, apparently with only minimal mingling, and flowed together along the same channel through the syenite of the stock.

Many of the shonkinite inclusions and dikes have along their margins irregular, dense to diffuse masses or patches of pegmatoid syenite, some amphibole-rich, gradational outward into normal syenite. This pegmatoid syenite probably reflects high concentrations of volatiles adjacent to the shonkinite dikes.

Some of the coarse-grained synplutonic shonkinite dikes contain phlogopite or biotite crystals that are distinctly lath- or blade-shaped, rather than platy or columnar. That is, these micas are strongly elongate in one direction parallel to the basal cleavage. These crystals are locally as long as $10 \mathrm{~cm}$. According to Hibbard (1995, p. 253-254) such "blade biotite" is characteristic of magmamixing environments. This hypothesis seems applicable to Mountain Pass, where lath-shaped biotite occurs only in some synplutonic dikes.

The informative and important field relations of synplutonic dikes are not well exposed anywhere else in the Mountain Pass district. ¡Please don't hammer on and destroy the evidence! Take photographs, not rocks. Samples of shonkinite and syenite are readily available nearby from near-source float.

Other geologic features

Return to the intersection of the secondary dirt road and Kokoweef Road. Three additional interesting geologic features are readily accessible from here.

(1) About $90 \mathrm{~m}$ northwest of the intersection, loose boulders on the southwest side of the road (Fig. 23, (2) provide good samples of coarse-grained amphibole syenite. Note traces of sulfide minerals.

(2) From the intersection, drive $\approx 0.3$ miles farther southeast on Kokoweef Road. At the top of a hill, turn off to the left (east) onto a prominent side road along the top of a ridge, and park. This locality (Fig. 23, (3); \{35.190, 24.284\}) affords an overview of the northern MP district and the REE mine, processing plants, and rock stockpiles and dumps; with Clark Mountain $(2420$ m, 7929 feet) and part of the Mojave National Preserve (Fig. 4) in the background. 
The mountains west and southwest of here are the Mescal Range, dominated by late Mesozoic thrust faults (Burchfiel and Davis, 1971, 1988). Among the units present in the eastern Mescal Range are three more characteristic of the Colorado Plateau than the Mojave Desert: Triassic Moenkopi and Chinle Formations and Jurassic Aztec Sandstone (Hewitt, 1956; Marzolf, 1983, 1988; Fleck and others, 1994; Busby and others, 2002, p. 80). Aztec Sandstone in this range locally contains dinosaur footprints (Reynolds, 1983).

(3) Return to the Bailey Road exit. Cross northward over I-15, and park in front of the (defunct) Mountain Pass post office (Fig. 23, (4). Roads west, southwest, and south of this parking area are lined with boulders and some smaller pieces of carbonatite from the Sulfide Queen stock. A few samples of fenite can also be found.

Two of the characteristic minerals in MP carbonatite, bastnäsite $\left(\mathrm{CeCO}_{3} \mathrm{~F}\right)$ and barite, are commonly difficult to distinguish in hand specimen. In much of the carbonatite, bastnäsite grains are, unfortunately, microscopic. Olson and others (1954, p. 34-35) describe mesoscopic characteristics of bastnäsite and barite in the Sulfide Queen carbonatite. Omitted text ([...]) pertains to rocks in the MP district other than the Sulfide Queen stock, or to properties of the minerals in thin section.

"The bastnaesite is light tan to honey colored, pale cream, yellow, greenish yellow, reddish yellow, and reddish brown. Bastnaesite crystallizes in the ditrigonal, dipyramidal class of the hexagonal system. Most of the crystals are tabular [...], flattened parallel to (0001). [...] many of the bastnaesite tablets are no more than $1 \mathrm{~mm}$ in length. The "bow-tie" structure of the tabular crystal masses is locally well developed. In addition to the tabular form, small hexagonal prisms [...] are found locally [...] Fracture surfaces are irregular and have a resinous luster. An indistinct prismatic cleavage is present. Bastnaesite from [MP] does not appear to have such perfect basal cleavage as that reported [from another locality] [...] [MP] bastnaesite has a hardness of about $4 \mathrm{H}$ and a specific gravity of about 5 . The mineral is soluble in strong sulfuric acid with evolution of [HF and $\mathrm{CO}_{2}$.]"

"The barite contains variable amounts of strontium, and some of the mineral is nearer celestite than barite in composition. The grain size of barite ranges widely, and is commonly about 0.5 to $1 \mathrm{~cm}$. The barite [...] typically occurs as coarse tabular or oval grains of white to pink or red color. Some of the barite has curved cleavage planes [...] In addition to the coarse grains, barite also occurs as fine-grained veinlets with or without quartz, along shear planes or fractures cutting other minerals of the carbonate rock. On rough weathered surfaces, the barite commonly stands in relief above the carbonate minerals. [...] many of the barite crystals, when broken, show lighter colored cores which have good prismatic cleavage, in contrast to the dull fine-grained outer zones. [...] the darker red variety of barite seems to be associated with the areas of abundant crocidolite and chlorite. Barite near silicified zones is predominantly white, although both pink and white barite occur in silicified carbonate rock. [...] Some white barite is rimmed and veined by pink barite." 
The density of barite $(4 \mathrm{H})$ is about the same as that of bastnäsite, but the hardness of barite

$(2 \mathrm{H}-3 \mathrm{H})$ is somewhat less. Supposedly, Mountain Pass bastnäsite will fluoresce a pale chartreuse green under ultraviolet light, but not all specimens seem to have this property. For larger crystals, a scintillometer or Geiger counter can aid in distinguishing bastnäsite from barite, as bastnäsite has higher concentrations of Th and U. However, the presence of thorite or other Th or U phases can confound this test.

Look also for veins of blue, acicular to fibrous riebeckite or crocidolite; and locally abundant small crystals of galena (Mitchell, 1973).

Acknowledgments

Cliff Hopson, Dennis Cox, and Ted Theodore originally inspired or encouraged my interest in Mountain Pass. Subsequently, several geologists and chemists have assisted with various aspects of my research there, or my studies of REE resource geology: John Benfield, Jim Calzia, Hank Crow, Ed DeWitt, Jim Hedrick, Caron Jones, Roy Knight, Paul Lamothe, John Landreth, Dave Miller, Doug Morton, Greta Orris, Jenny Prennace, Joe Taggart, and Chet Wrucke. Thanks also to Cori Hoag and Dave Maher of the Arizona Geological Society for arranging the field trip; to Ed McNew and Geoff Nason of Molycorp for conducting the mine tour; and to Jim Hedrick, Cori Hoag, Eric Jensen, Steve Ludington, Geoff Nason, and Brock O'Kelley for reviewing part or all of this article.

References Cited

Anders, E. and Grevesse, N., 1989, Abundances of the elements: meteoritic and solar: Geochimica et Cosmochimica Acta, v. 53, p. 197-214.

Anderson, J.L., 1989, Proterozoic anorogenic granites of the southwestern United States of America, in Jenney, J. P., and Reynolds, S. J., editors, Geologic evolution of Arizona: Arizona Geological Society Digest v. 17, p. 211-238.

Anonymous, 1952, Southern California's rare-earth bonanza: Engineering and Mining Journal, v. 153 , no. 1, p. 100-102.

Antia, M., 1999, From a new phosphor, a double crop of photons: Science, v. 283, p. 617.

Aoki, K., Ishiwaka, I., and Kanisawa, S., 1981, Fluorine geochemistry of basaltic rocks from continental and oceanic regions and petrogenetic application: Contributions to Mineralogy and Petrology, v. 76, p. 53-59.

Baedecker, P.A., and McKown, D.M., 1987, Instrumental neutron activation analysis of geochemical samples, in Baedecker, P.A., Methods for geochemical analysis: U.S. Geological Survey Bulletin 1770, p. H1-H14.

Barnum, E.C., 1989, Lanthology: applications of lanthanides and the development of Molycorp's Mountain Pass operations, in The California desert mineral symposium, Compendium:

Sacramento, California, U.S. Bureau of Land Management, p. 245-249.

Bell, K., 1989, editor, Carbonatites, genesis and evolution: Unwin Hyman, 618 p.

Bell, K., and Blenkinsop, J., 1989, Neodymium and strontium isotope geochemistry of carbonatites, in Bell, K., 1989, editor, Carbonatites, genesis and evolution: Unwin Hyman, p. 278-300.

Bell, K., and Tilton, G.R., 2002, Probing the mantle: the story from carbonatites: EOS, v. 83, no. 24, p. $273,276-277$.

Bergman, S.C., 1987, Lamproites and other potassium-rich rocks: A review of their occurrence, mineralogy, and geochemistry, in Fitton, J.G., and Upton, B.G.J., editors, Alkaline igneous rocks: Geological Society of London, Special Publication 30, p. 103-190.

Blasse, G., and Grabmaier, B.C., 1994, Luminescent materials: Springer-Verlag, 232 p. 
Burchfiel, B.C., and Davis, G.A., 1971, Clark Mountain thrust complex in the Cordillera of southeastern California: Geologic summary and field trip guide, in Elders, W.A., editor, Geological excursions in southern California: Campus Museum Contributions Number 1, University of California, Riverside, p. 1-28.

Burchfiel, B.C., and Davis, G.A., 1988, Mesozoic thrust faults and Cenozoic low-angle normal faults, eastern Spring Mountains, Nevada, and Clark Mountains thrust complex, California, in Weide, D.L., and Faber, M.L., editors, This extended land: Geological journeys in the southern Basin and Range: Geological Society of America Field Trip Guidebook, p. 87106.

Busby, C.J., Schermer, E.R., and Mattinson, J.M., 2002, Extensional arc setting and ages of Middle Jurassic eolianites, Cowhole Mountains (eastern Mojave Desert block, California), in Glazner, A.F., Walker, J.D., and Bartley, J.M., editors, Geologic evolution of the Mojave Desert and southwestern Basin and Range: Geological Society of America Memoir 195, p. 79-91.

Castor, S.B., 1990, Rare earth resources: comparisons of the geology of existing and potential resources, in Geitgey, R.P., and Vogt, B.F., editors, Industrial rocks and minerals of the Pacific northwest: Oregon Department of Geology and Mineral Industries Special Paper 23, p. 73-78.

Castor, S.B., 1991, Rare earth deposits in the southern Great Basin, in Raines, G.L., Lisle, R.E., Schafer, R.W., and Wilkinson, W.H., editors, Geology and ore deposits of the Great Basin: Geological Society of Nevada, Symposium Proceedings, p. 523-528.

Castor, S.B., 1993, Rare earth deposits and Proterozoic anorogenic magmatism, in Maurice, Y.T., editor, Proceedings of the eighth quadrennial IAGOD symposium, p. 331-340.

Castor, S.B., 1994, Rare earth minerals in Carr, D.D., editor, Industrial minerals and rocks (6th edition): Littleton, Colorado, Society for Mining, Metallurgy, and Exploration, p. 827-839.

Castor, S.B., and Gleason, J.D., 1989, Proterozoic ultrapotassic intrusive rocks in southeastern California: Geological Society of America Abstracts with Programs, v. 21, no. 5, p. 64.

Cotton, S., 1991, Lanthanides and actinides: Oxford, 192 p.

Cowan, J.J., and Thielemann, F.-K., 2004, R-process nucleosynthesis in supernovae: Physics Today, v. 57, no. 10 , p. 47-53.

Crow, H.C., 1984, Geochemistry of shonkinites, syenites, and granites associated with the Sulfide Queen carbonatite body, Mountain Pass, California: University of Nevada, Las Vegas, M.S. thesis, $56 \mathrm{p}$.

Cullers, R.L., and Graf, J.L., 1984, Rare earth elements in igneous rocks of the continental crust: predominantly basic and ultrabasic rocks, in Henderson, P., editor, Rare earth element geochemistry: Elsevier, p. 237-274.

Deer, W.A., Howie, R.A., and Zussman, J., 1992, An introduction to the rock-forming minerals (second edition): Longman, p. 488-495.

DePaolo, D.J., and Wasserburg, G.J., 1976, Inferences about magma sources and mantle structure from variations of ${ }^{143} \mathrm{Nd} /{ }^{144} \mathrm{Nd}$ : Geophysical Research Letters, v. 3, p. 743746.

DeWitt, E., 1987, Proterozoic ore deposits of the southwestern U.S.: Society of Economic Geologists Guidebook Series, v. 1, 189 p.

DeWitt, E., Kwak, L.M., and Zartman, R.E., 1987, U-Th-Pb and ${ }^{40} \mathrm{Ar} /{ }^{39} \mathrm{Ar}$ dating of the Mountain Pass carbonatite and alkalic igneous rocks, southeastern California: Geological Society of America Abstracts with Programs, v. 19, no. 7, p. 642.

Emsley, J., 1998, The elements (3d edition): Oxford, $292 \mathrm{p.}$

Evans, J.R., 1966, California's Mountain Pass mine now producing europium oxide: California Division of Mines and Geology, Mineral Information Service, v. 19, no. 1, p. 23-32.

Evans, J.R., 1971, Geology and mineral deposits of the Mescal Range quadrangle, San Bernardino County, California: California Division of Mines and Geology Map Sheet 17, scale $1: 62,500$.

Faulds, J.E., Feuerbach, D.L., Miller, C.F., and Smith, E.I., 2001, Cenozoic evolution of the northern Colorado River extensional corridor, southern Nevada and northwest Arizona, in Erskine, M.C., Faulds, J.E., Bartley, J.M., and Rowley, P.D., editors, The geologic transition, High Plateaus to Great Basin-A symposium and field guide: Utah Geological Association Publication 30, p. 239-274.

Fleck, R.J., Mattinson, J.M., Busby, C.J., Carr, M.D., Davis, G.A., and Burchfiel, B.C., 1994, Isotopic complexities and the age of the Delfonte volcanic rocks, eastern Mescal Range, 
southeastern California; stratigraphic and tectonic implications: Geological Society of America Bulletin, v. 106, p. 1242-1253.

Fleischer, M., 1978, Relative proportions of the lanthanides in minerals of the bastnaesite group: Canadian Mineralogist, v. 16, p. 361-363.

Foley, S.F., 1992, Petrological characterization of the source components of potassic magmas: geochemical and experimental constraints: Lithos, v. 28, no. 3-6, p. 187-204.

Foley, S.F., Venturelli, G., Green, D.H., and Toscani, L., 1987, The ultrapotassic rocks: characteristics, classification, and constraints for petrogenetic models: Earth-Science Reviews, v. 24, p. 81-134.

Friedmann, S.J., Davis, G.A., and Fowler, T.K., 1996, Geometry, paleodrainage, and geologic rates from the Miocene Shadow Valley supradetachment basin, eastern Mojave Desert, California, in Beratan, K., editor, Reconstructing the history of Basin and Range extension using sedimentology and stratigraphy: Geological Society of America Special Paper 303, p. 85-105.

Gast, P.W., 1968, Trace element fractionation and the origin of tholeiitic and alkaline magma types: Geochimica et Cosmochimica Acta, v. 32, p. 1057-1086.

Gill, J.B., 1981, Orogenic andesites and plate tectonics: Springer-Verlag, 390 p.

Gittins, J., 1989, The origin and evolution of carbonatite magmas, in Bell, K., editor, Carbonatites, genesis and evolution: Unwin Hyman, p. 580-600.

Gleason, J.D., Miller, C.F., Wooden, J.L., and Bennett, V.C., 1994, Petrogenesis of the highly potassic $1.42 \mathrm{Ga}$ Barrel Spring pluton, southeastern California, with implications for midProterozoic magma genesis in the southwestern USA: Contributions to Mineralogy and Petrology, v. 118 , p. 182-197.

Greenwood, N.N., and Earnshaw, A., 1997, Chemistry of the elements (second edition): Butterworth-Heinemann, $1340 \mathrm{p}$.

Harrah, H.W., 1967, Rare earth concentration at Molybdenum Corporation of America; solvent extraction plant: Deco Trefoil, v. 31, no. 5, p. 9-16.

Haskin, L.A., , 1989, Rare earth elements in lunar materials, in Lipin, B.R., and McKay, G.A., editors, Geochemistry and mineralogy of rare earth elements: Reviews in Mineralogy, $v$. 21, p. 227-258.

Hatch, F.H., Wells, A.K., and Wells, M.K., 1972, Petrology of the igneous rocks (thirteenth edition): Murby, p. 83-84, 174-175.

Haxel, G.B., 1998, Ultrapotassic phlogopite shonkinite at Mountain Pass, southern California: comparison with lamproites: Geological Society of America Abstracts with Programs, v. 30 , no. 6 , p. 10.

Haxel, G.B., Hedrick, J.B., and Orris, G.J., 2002, Rare earth elements-critical resources for high technology: U.S. Geological Survey Fact Sheet 087-02, 4 p.

Haxel, G.B., in press 1, Ultrapotassic rocks, carbonatite, and rare earth element deposit, Mountain Pass, southern California, in Theodore, T.G., editor, Geology and mineral resources of the Mojave National Preserve, southern California: U.S. Geological Survey Bulletin 2160.

Haxel, G.B., in press 2, Geochemistry, mineralogy, and resource geology of the rare earth elements, in Orris G.J., and Haxel, G.B., editors, Rare earth element resources: A basis for high technology: University of Arizona and U.S. Geological Survey, Center for Mineral Resources, Monographs in Mineral Resource Science.

Hedrick, J.B., 1988, Availability of rare earths: Ceramic Bulletin, v. 67, p. 858-861.

Hedrick, J.B., 1995, The global rare-earth cycle: Journal of Alloys and Compounds, v. 225, p. 609-618.

Hedrick, J.B., and Haxel, G.B., in press, Mining and processing of the principal rare earth element ore minerals, and chemical separation of the rare earth elements, in Orris G.J., and Haxel, G.B., editors, Rare earth element resources: A basis for high technology: University of Arizona and U.S. Geological Survey, Center for Mineral Resources, Monographs in Mineral Resource Science.

Heinrich, E.W., 1966, The geology of carbonatites: Rand McNally, 555 p.

Henderson, P., 1984, editor, Rare earth element geochemistry: Elsevier, 510 p.

Hewett, D.F., 1954, Forward: History of discovery at Mountain Pass, California, in Olson, J.E., Shawe, D.R., Pray, L.C., and Sharp, W.N., 1954, Rare-earth mineral deposits of the Mountain Pass district, San Bernardino County, California: U.S. Geological Survey Professional Paper 261, p. iii-vi. 
Hewett, D.F., 1956, Geology and mineral resources of the Ivanpah quadrangle, California and Nevada: U.S. Geological Survey Professional Paper 275, 172 p.

Hibbard, M.J., 1995, Petrography to petrogenesis: Prentice Hall, 587 p.

Jaffe, H.W., Meyrowitz, R., and Evans, H.T., Jr., 1953, Sahamalite, a new rare earth carbonate mineral: American Mineralogist, v. 38, p. 741-754.

Jennings, C.R., 1961, compiler, Geologic map of California, Kingman Sheet: California Division of Mines and Geology, scale 1:250,000.

Johnson, G.W., and Sisneros, T.E., 1982, Analysis of rare earth elements in ore concentrate samples using direct current plasma spectroscopy: The rare earths in modern science and technology, v. 3: Plenum, p. 525-529.

Jones, A.P., 1996, Upper-mantle enrichment by kimberlitic or carbonatitic magmatism, in Bell, K., editor, Carbonatites, genesis and evolution: Unwin Hyman, p. 448-463.

Jones, A.P. and Ekambaram, V., 1985, New INAA analysis of a mantle-derived titanate mineral of the crichtonite series, with particular reference to the rare earth elements: American Mineralogist, v. 70, p. 414-418.

Jones, A.P., Wall, F., and Williams, C.T., 1996, editors, Rare earth minerals; Chemistry, origin, and ore deposits: Chapman and Hall, 372 p.

Kaczmarek, J., 1981, Discovery and commercial separations, in Gschneidner, K.A., Jr., editor, Industrial applications of the rare earth elements: American Chemical Society Symposium Series 164, p. 135-166.

Kaltsoyannis, N., and Scott, P. 1999, The f elements: Oxford, 85 p.

Kargel, J.S., and Lewis, J.S., 1993, The composition and early evolution of Earth: Icarus, v. 105, p. $1-25$.

Kilbourn, B.T., 1992, Cerium: A guide to its role in chemical technology: White Plains, New York, Molycorp, 42 p. [Available at www.molycorp.com/Cerium_Book.pdf.]

Kilbourn, B.T., 1993a, A lanthanide lanthology (Part 1, A-L): White Plains, New York, Molycorp, Inc., 61 p. [Available at www.molycorp.com/Lanthology_A-L.pdf.]

Kilbourn, B.T., 1993b, Cerium and cerium compounds, in Kirk, R.E., Othmer, D.F., Kroschwitz, J.I., and Howe-Grant, M., editors, Encyclopedia of chemical technology (fourth edition): Wiley, v. 5, p. 728-749.

Kilbourn, B.T., 1994, A lanthanide lanthology (Part 2, M-Z): White Plains, New York, Molycorp, Inc., 55 p. [Available at www.molycorp.com/Lanthology_M-Z.pdf.]

Le Maitre, R.W., 1976, The chemical variability of some common igneous rocks: Journal of Petrology, v. 17, p. 589-637.

Lipin, B.R., and McKay, G.A., 1989, editors, Geochemistry and mineralogy of rare earth elements: Reviews in Mineralogy, v. 21, 348 p.

Luhr, J.F., 1997, Extensional tectonics and the diverse primitive volcanic rocks in the Western Mexican Volcanic Belt, in Nixon, G.T., Johnston, A.D., and Martin, R.F., editors, Nature and origin of primitive magmas at subduction zones: Canadian Mineralogist, v. 35, part 2, p. 473-500.

Mariano, A.N., 1989a, Nature of economic mineralization in carbonatites and related rocks, in Bell, K., editor, Carbonatites, genesis and evolution: Unwin Hyman, p. 149-176.

Mariano, A.N., 1989b, Economic geology of rare earth elements, in Lipin, B.R., and McKay, G.A., editors, Geochemistry and mineralogy of rare earth elements: Reviews in Mineralogy, v. 21, p. 309-337.

Marzolf, J.E., 1983, Early Mesozoic eolian transition from cratonal margin to orogenic-volcanic arc, in Gurgel, K.D., editor, Geologic excursions in stratigraphy and tectonics: from southeastern Idaho to the southern Inyo Mountains, California, via Canyonlands and Arches National Parks, Utah, Guidebook, Part II: Utah Geological and Mineral Survey Special Studies 60, p. 39-46.

Marzolf, J.E., 1988, Reconstruction of Late Triassic and Early and Middle Jurassic sedimentary basins: southwestern Colorado Plateau to the eastern Mojave Desert, in Weide, D.L., and Faber, M.L., editors, This extended land: Geological journeys in the southern Basin and Range: Geological Society of America Field Trip Guidebook, p. 177-200.

McCurry, M.O., 1988, Geology and petrology of the Woods Mountains volcanic center, southeastern California: implications for the genesis of peralkaline rhyolite ash flow tuffs: Journal of Geophysical Research, v. 93, no. B12, p. 14,835-14,855.

McKenzie, D., 1985, Some remarks on the movement of small melt fractions in the mantle: Earth and Planetary Science Letters, v. 95, p. 53-72. 
McKown, D.M., and Millard, H.T., Jr., 1987, Determination of uranium and thorium by delayed neutron counting, in Baedecker, P.A., Methods for geochemical analysis: U.S. Geological Survey Bulletin 1770, p. 11-13.

Miller, C.F., Miller, J.S., and Faulds, J.E., 2005, Miocene volcano-plutonic systems, southern Nevada: a window into upper crustal magmatic processes, in Stevens, C., and Cooper, J. editors, Western Great Basin geology, Fieldtrip 9, Fieldtrip Guidebook and Volume, Pacific Section SEPM Publishers, Book 99, p. 37-66.

Miller, D.M., Miller, R.J., Nielsen, J.E., Wilshire, H.G., Howard, K.A., and Stone, Paul, compilers, in press, Geologic map of the East Mojave National Preserve, California, in Theodore, T.G., editor, Geology and mineral resources of the Mojave National Preserve, southern California: U.S. Geological Survey Bulletin 2160, plate 1, scale 125:000.

Mitchell, R.H., 1973, Isotopic composition of lead in galena from the Mountain Pass carbonatite, California: Nature Physical Science, v. 241, p. 17-18.

Mitchell, R.H., 1996a, editor, Undersaturated alkaline rocks: mineralogy, petrogenesis, and economic potential: Mineralogical Association of Canada, Short Course Volume 24, 312 p.

Mitchell, R.H., 1996b, Classification of undersaturated and related alkaline rocks, in Mitchell, R.H., editor, Undersaturated alkaline rocks: mineralogy, petrogenesis, and economic potential: Mineralogical Association of Canada, Short Course Volume 24, p. 1-22.

Mitchell, R.H., 1996c, Undersaturated potassic plutonic complexes, in Mitchell, R.H., editor, Undersaturated alkaline rocks: mineralogy, petrogenesis, and economic potential: Mineralogical Association of Canada, Short Course Volume 24, p. 193-216.

Mitchell, R.H., and Bergman, S.C., 1991, Petrology of lamproites: Plenum, 447 p.

Morton, D.M., Watson, K.D., and Baird, A.K., 1991, Alkalic silicate rocks of the Mountain Pass district, San Bernardino County, California, in Reynolds, R.E., compiler, Crossing the borders: Quaternary studies in eastern California and southwestern Nevada: Redlands, California, Mojave Desert Quaternary Research Center, San Bernardino County Museum Association, Special Publication, p. 90-96.

Nakamura, N., 1974, Determination of REE, Ba, Mg, Na, and $\mathrm{K}$ in carbonaceous and ordinary chondrites: Geochemica et Cosmochimica Acta, v. 38, p. 757-775.

Nelson, D.R., Chivas, A.R., Chappell, B.W., and McCulloch, M.T., 1988, Geochemical and isotopic systematics in carbonatites and implications for the evolution of ocean-island sources: Geochimica et Cosmochimica Acta, v. 52, p. 1-17.

Nixon, G.T., and Johnston, A.D., 1997, Nature and origin of primitive magmas at subduction zones; Preface, in Nixon, G.T., Johnston, A.D., and Martin, R.F., editors, Nature and origin of primitive magmas at subduction zones: Canadian Mineralogist, v. 35, part 2, p. 253256.

Nixon, G.T., Johnston, A.D., and Martin, R.F., 1997, editors, Nature and origin of primitive magmas at subduction zones: Canadian Mineralogist, v. 35, part 2, p. 253-570.

Olson, J.E., and Pray, L.C., 1954, The Mountain Pass rare-earth deposits, in Mineral deposits and mineral industry, chapter 8, in Jahns, R.H., editor, Geology of southern California: California Division of Mines Bulletin 170, p. 23-39.

Olson, J.E., Shawe, D.R., Pray, L.C., and Sharp, W.N., 1954, Rare-earth mineral deposits of the Mountain Pass district, San Bernardino County, California: U.S. Geological Survey Professional Paper 261, 75 p.

Orris, G.J., Hedrich, J.B., and Haxel, G.B., in press, Mineral economics of the rare earth elements, in Orris G.J., and Haxel, G.B., editors, Rare earth element resources: A basis for high technology: University of Arizona and U.S. Geological Survey, Center for Mineral Resources, Monographs in Mineral Resource Science.

Orris G.J., and Haxel, G.B., in press, editors, Rare earth element resources: A basis for high technology: University of Arizona and U.S. Geological Survey, Center for Mineral Resources, Monographs in Mineral Resource Science.

Pitcher, W.S., 1993, The nature and origin of granite: Blackie, 321 p.

Powell, J.L., Hurley, P.M., and Fairbain, H.W., 1966, The strontium isotopic composition and origin of carbonatites, in Tuttle, O.F., and Gittins, J., editors, Carbonatites: Interscience, p. 365-378.

Rayner-Canham, G., 1996, Descriptive inorganic chemistry: Freeman, 492 p.

Reilly, W.K., 1991, Free enterprise - technology - and cleaner environment: Business Week, no. 3246, December 30, 1991. 
Reynolds, R.E., 1983, Jurassic trackways in the Mescal Range, San Bernardino County, California, in Gurgel, K.D., editor, Geologic excursions in stratigraphy and tectonics: from southeastern Idaho to the southern Inyo Mountains, California, via Canyonlands and Arches National Parks, Utah, Guidebook-Part II: Utah Geological and Mineral Survey Special Studies 60, p. 46-48.

Rock, N.M.S., 1991, Lamprophyres: Van Nostrand Reinhold, 285 p.

Rossotti, H., 1998, Diverse atoms; Profiles of the chemical elements: Oxford, 587 p.

Sabot, J.-L., and Maestro, P., 1995, Lanthanides, in Kirk, R.E., Othmer, D.F., Kroschwitz, J.I., and Howe-Grant, M., editors, Encyclopedia of chemical technology (fourth edition): Wiley, v. 14, p. 1091-1115.

Sato, H., 1977, Nickel content of basaltic magmas: identification of primary magmas and a measure of the degree of olivine fractionation: Lithos, v. 10, p. 113-120.

Schubert, E.F., and Kim, J.K., 2005, Solid-state light sources getting smart: Science, v. 308, p. 1274-1278. [References in this paper to "cesium-doped yttrium-aluminium-garnet (YAG)" are misprints. The correct compound is cerium-doped YAG (E.F. Schubert, written communication, 2005).]

Shannon, R.D., 1976, Revised effective ionic radii and systematic studies of interatomic distances in halides and chalcogenides: Acta Crystallographica, v. 32, p. 751-767.

Sigma-Aldrich Company, 2002, Aldrich handbook of fine chemicals and laboratory equipment, 2003-2004: Milwaukee, Wisconsin, 3166 p.

Smets, B.M.J., 1987, Phosphors based on rare-earths, a new era in fluorescent lighting: Materials Chemistry and Physics, v. 16, p. 283-299.

Smets, B., 1991, New applications of efficient phosphors, in Bartolo, B.D., and Chen, X., editors, Advances in nonradiative processes in solids: Plenum, p. 353-386.

Sneden, C., and Cowan, J.J., 2003, Genesis of the heaviest elements in the Milky Way galaxy: Science, v. 299, p. 70-75.

Sun, S.-S., and McDonough, W.F., 1989, Chemical and isotopic systematics of oceanic basalts: implications for mantle compositions and processes, in Saunders, A.D., and Norry, M.J., editors, Magmatism in the ocean basins: Geological Society of London Special Publication 42, p. 313-345.

Tatsumi. Y., and Eggins, S., 1995, Subduction zone magmatism: Blackwell, 211 p.

Taylor, S.R., and McLennan, S.M., 1985, The continental crust: its composition and evolution. An examination of the geochemical record preserved in sedimentary rocks: Blackwell, $312 \mathrm{p}$.

Taylor, S.R., and McLennan, S.M., 1988, The significance of the rare earth elements in geochemistry and cosmochemistry, in Gschneidner, K.A., Jr., and Eyring, L., editors, Handbook on the chemistry and physics of the rare earths: Elsevier, v. 11, chapter 79, p. 485-578.

Theodore, T.G., in press, editor, Geology and mineral resources of the Mojave National Preserve, southern California: U.S. Geological Survey Bulletin 2160.

Waychunas, G.A., 2002, Apatite luminescence, in Kohn, M.J., Rakovan, J., and Hughes, J.M., editors, Phosphates: geochemical, geobiological, and materials importance: Reviews in Mineralogy and Geochemistry, v. 48, p. 701-742.

Wedepohl, K.H., 1995, Composition of the continental crust: Geochimica et Cosmochimica Acta, v. 59 , p. $1217-1223$.

Wegh, R.T., Donker, H., Oskam, K.D., and Meijerink, A., 1999, Visible quantum cutting in $\mathrm{LiGdF}_{4}: \mathrm{Eu}^{3+}$ through downconversion: Science, v. 283, p. 663-666.

Welker, T., 1991, Recent developments on phosphors for fluorescent lamps and cathode-ray tubes: Journal of Luminescence, v. 48 \& 49, p. 49-56.

Williams-Jones, A.E., and Wood, S.A., 1992, A preliminary petrogenetic grid for REE fluorocarbonates and associated minerals: Geochimica et Cosmochimica Acta, v. 56, p. 725-738.

Wooden, J.L., and Miller, D.M., 1990, Chronologic and isotopic framework for Early Proterozoic crustal evolution in the eastern Mojave Desert region, southeastern California: Journal of Geophysical Research, v. 95, no. B12, p. 20,133-20,146.

Woolley, A.R., and Kempe, D.R.C., 1989, Carbonatites: nomenclature, average chemical composition, and element distribution, in Bell, K., editor, Carbonatites, genesis and evolution: Unwin Hyman, p. 1-14.

Wyllie, P.J., 1989, Origin of carbonatites: evidence from phase equilibrium studies, in Bell, K., editor, Carbonatites, genesis and evolution: Unwin Hyman, p. 500-545. 
Wyllie, P.J., Jones, A.P., and Deng, J., 1996, Rare earth elements in carbonate-rich melts from mantle to crust, in Jones, A.P., Wall, F., and Williams, C.T., editors, Rare earth minerals; Chemistry, origin, and ore deposits: Chapman and Hall, p. 77-103. 
Table 1. The rare earth elements: the lanthanides, La to Lu, and $\mathrm{Y}\{1\}$.

\begin{tabular}{|c|c|c|c|c|c|c|c|c|c|c|c|}
\hline \multirow[b]{2}{*}{ Symbol } & \multirow[b]{2}{*}{ Name } & \multirow[b]{2}{*}{$\begin{array}{c}Z \\
\{2\}\end{array}$} & \multirow{2}{*}{$\begin{array}{l}\text { Number } \\
\text { of extant } \\
\text { isotopes }\end{array}$} & \multirow[b]{2}{*}{$\begin{array}{l}\text { Atomic } \\
\text { mass }\end{array}$} & \multicolumn{3}{|c|}{ Electron configuration $\{3\}$} & \multirow{2}{*}{$\begin{array}{c}\text { Ionic } \\
\text { radius } \\
(\AA)\{4\}\end{array}$} & \multicolumn{2}{|c|}{ Concentration (ug/g) } & \multirow[b]{2}{*}{ Derivation of name } \\
\hline & & & & & $\operatorname{Ln}^{0}$ & $\mathrm{Ln}^{3+}$ & other & & $\begin{array}{c}\text { Chondrites } \\
\{5\}\end{array}$ & $\begin{array}{c}\text { UCC } \\
\{6\}\end{array}$ & \\
\hline $\mathrm{La}$ & lanthanum & 57 & 2 & 138.9055 & ; 4f $05 \mathrm{~d} 16 \mathrm{~s} 2$ & ; 4f 0 & & 1.160 & 0.329 & 30. & "to lie hidden" (Greek) \\
\hline $\mathrm{Ce}$ & Cerium & 58 & 4 & 140.115 & ; 4f $26 \mathrm{~s} 2\{7\}$ & ; 4f $14 \mathrm{f} 0$ & $\mathrm{Ce} 4+: ;$ f 0 & $1.143,0.97$ & 0.865 & 64. & The asteroid Ceres \\
\hline $\operatorname{Pr}$ & praseodymium & 59 & 1 & 140.90765 & ; 4f $36 \mathrm{~s} 2$ & ; 4f 2 & & 1.126 & 0.116 & 7.1 & "leek-green twin" (Greek) $\{8\}$ \\
\hline $\mathrm{Nd}$ & neodymium & 60 & 7 & 144.24 & ; 4f $46 \mathrm{~s} 2$ & ; 4f 3 & & 1.109 & 0.630 & 26. & “new twin” (Greek) $\{8\}$ \\
\hline $\mathrm{Pm}$ & promethium & 61 & 0 & $145\{9\}$ & ; 4f $56 \mathrm{~s} 2$ & ; 4f 4 & & 1.093 & effect & & $\begin{array}{l}\text { Prometheus, in Greek mythology } \\
\text { the Titan who gave fire to humans }\end{array}$ \\
\hline $\mathrm{Sm}$ & samarium & 62 & 7 & 150.36 & ; 4f $66 \mathrm{~s} 2$ & ; 4f 5 & & 1.079 & 0.203 & 4.5 & $\begin{array}{l}\text { The mineral samarskite, named for a } \\
\text { Russian engineer }\end{array}$ \\
\hline $\mathrm{Eu}$ & europium & 63 & 2 & 151.965 & ; 4f $76 \mathrm{~s} 2$ & ; 4f 6 & Eu2+: ; 4f 7 & $1.066,1.25$ & 0.077 & 0.88 & Europe \\
\hline $\mathrm{Gd}$ & gadolinium & 64 & 7 & 157.25 & ; 4f $75 \mathrm{~d} 16 \mathrm{~s} 2$ & ; 4f 7 & & 1.053 & 0.276 & 3.8 & $\begin{array}{l}\text { J. Gadolin, Finnish mineralogist, } \\
\text { discoverer of } Y\end{array}$ \\
\hline $\mathrm{Tb}$ & terbium & 65 & 1 & 158.92534 & ; 4f $96 \mathrm{~s} 2$ & ; 4f 8 & & 1.040 & 0.052 & 0.64 & Ytterby, a Swedish village \\
\hline Dy & dysprosium & 66 & 7 & 162.50 & ; 4f $106 \mathrm{~s} 2$ & ; 4f 9 & & 1.027 & 0.343 & 3.5 & "hard to obtain" (Greek) \\
\hline Ho & holmium & 67 & 1 & 164.93032 & ; 4f $116 \mathrm{~s} 2$ & ; 4f 10 & & 1.015 & 0.071 & 0.80 & Holmia, Stockholm (Latin) \\
\hline $\mathrm{Er}$ & erbium & 68 & 6 & 167.26 & ; 4f $126 \mathrm{~s} 2$ & ; 4f 11 & & 1.004 & 0.225 & 2.3 & Ytterby \\
\hline $\mathrm{Tm}$ & thulium & 69 & 1 & 168.93421 & ; 4f $136 \mathrm{~s} 2$ & ; 4f 12 & & 0.994 & 0.034 & 0.33 & $\begin{array}{l}\text { Thule, "most northerly land", } \\
\text { ancient name for Scandinavia (Latin) }\end{array}$ \\
\hline $\mathrm{Yb}$ & ytterbium & 70 & 7 & 173.04 & ; 4f $146 \mathrm{~s} 2$ & ; 4f 13 & & 0.985 & 0.220 & 2.2 & Ytterby \\
\hline $\mathrm{Lu}$ & lutetium & 71 & 2 & 174.967 & ; 4f $145 \mathrm{~d} 16 \mathrm{~s} 2$ & ; 4f 14 & & 0.977 & 0.0339 & 0.32 & Lutetia, Paris (Latin) \\
\hline $\mathrm{Y}$ & yttrium & 39 & 1 & 88.90585 & {$[\mathrm{Kr}] 4 \mathrm{~d} 15 \mathrm{~s} 2$} & {$[\mathrm{Kr}]$} & & 1.019 & 2.00 & 22. & Ytterby \\
\hline
\end{tabular}

\{1\} Data from Emsley (1998), Shannon (1976), Nakumura (1974), Taylor and McLennan (1985), Greenwood and Earnshaw (1997). Electronegativity (Pauling) ranges from 1.10 for La to 1.27 for Lu.

$\{2\} \quad \mathrm{Z}=$ atomic number.
$\{3\} \quad$; designates the Xe core, $\cdots 4 \mathrm{~d}^{10}{ }_{3 \mathrm{~s}}^{2} 5 \mathrm{p}_{4+}^{6} ;[\mathrm{Kr}]$, the $\mathrm{Kr}$ core.

\{4\} In eight-fold coordination, for $\mathrm{Ln}^{3+}, \mathrm{Ce}^{4+}$, and $\mathrm{Eu}^{2+} .1 \AA=100 \mathrm{pm}$

\{5\} Total lanthanides, $3.47 \mu \mathrm{g} / \mathrm{g}$; total REE (lanthanides $+\mathrm{Y}$ ), $5.47 \mu \mathrm{g} / \mathrm{g}$.
\{6\} UCC, upper continental crust. Total lanthanides, $146 \mu \mathrm{g} / \mathrm{g}$; total REE (lanthanides + Y), $168 \mu \mathrm{g} / \mathrm{g} ; \mathrm{La}+\mathrm{Ce}+\mathrm{Pr}+\mathrm{Nd}, 127 \mu \mathrm{g} / \mathrm{g} ; \mathrm{La}+\mathrm{Ce}+\mathrm{Pr}+\mathrm{Nd}+\mathrm{Y}, 149$

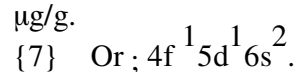

$\{8\}$ Mixtures of Pr and Nd were once called didymium (Di; Greek "twin" or "double"),

a term and symbol occasionally found in the older geochemical literature. \{9\} Longest-lived isotope is $145 \mathrm{Pm}$, half-life $17.1 \mathrm{a}$ 


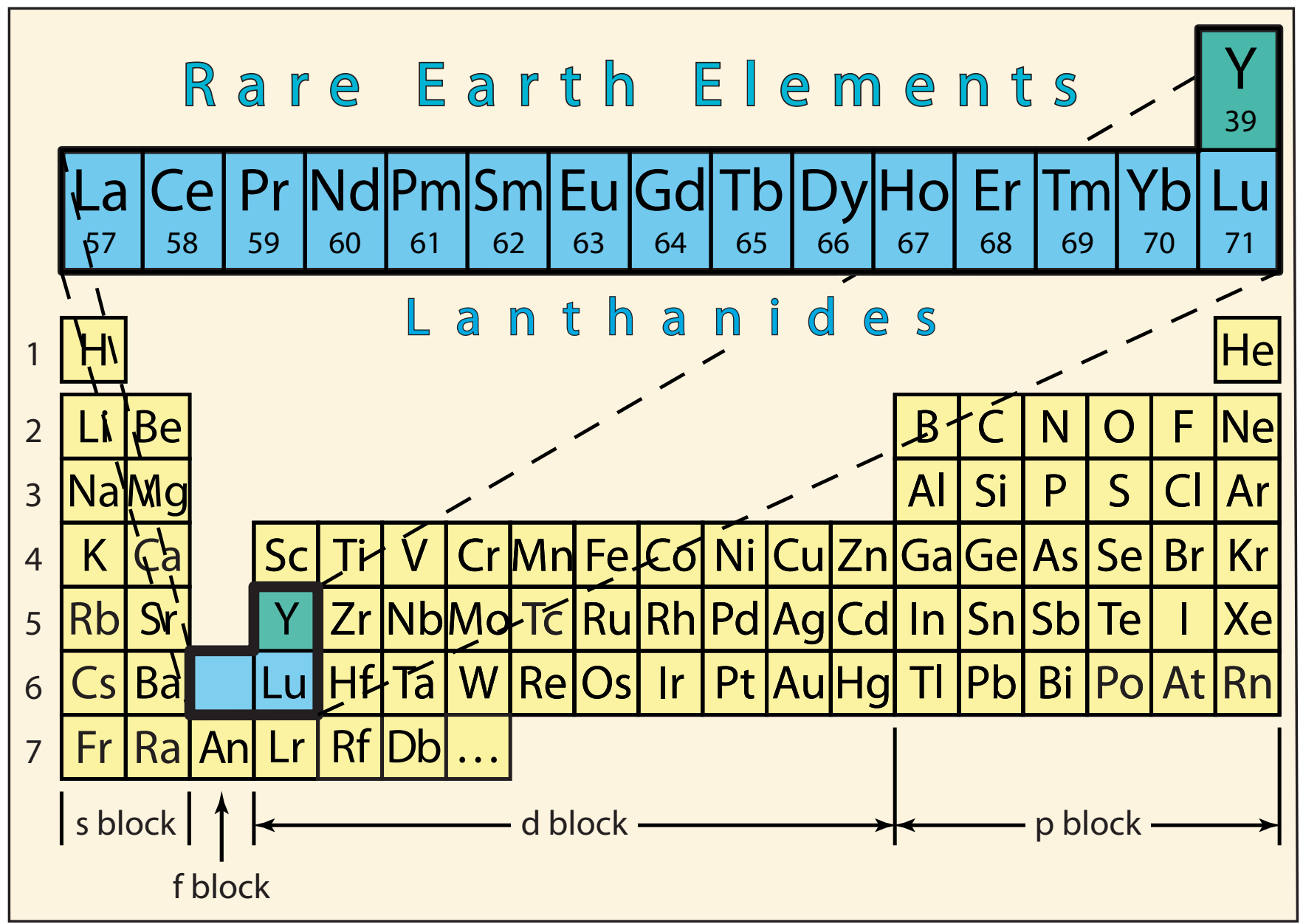

The rare earth elements

La lanthanum

Ce cerium

Pr praseodymium

Nd neodymium

(Pm promethium)

$\mathrm{Sm}$ samarium

$\mathrm{Eu}$ europium

Gd gadolinium

Tb terbium

Dy dysprosium

Ho holmium

Er erbium

Tm thulium

$\mathrm{Yb}$ ytterbium

Lu lutetium

$Y \quad$ yttrium

Figure 1. Chemical periodic table delineating the fifteen rare earth elements (REE): the lanthanides, ${ }_{57} \mathrm{La}$ through ${ }_{71} \mathrm{Lu}$, except for Pm, plus ${ }_{39} \mathrm{Y}$; and a list of the REE and their symbols (Table 1). Promethium is excluded from REE as used in geochemistry because it has no long-lived isotopes and occurs naturally on Earth only locally and in vanishingly small quantities. The first 14 lanthanides, $\mathrm{La}-\mathrm{Yb}$, belong to the period-six f block; the final lanthanide, $\mathrm{Lu}$, is the first member of the period-six d block. In period seven, An represents the $14 \mathrm{f}$-block actinide elements ( $\mathrm{Ac}, \mathrm{Th}, \mathrm{Pa}, \mathrm{U}, \mathrm{Np}, \mathrm{Pu}, \ldots \mathrm{No}) ; \mathrm{Lr}$ is the final actinide. 

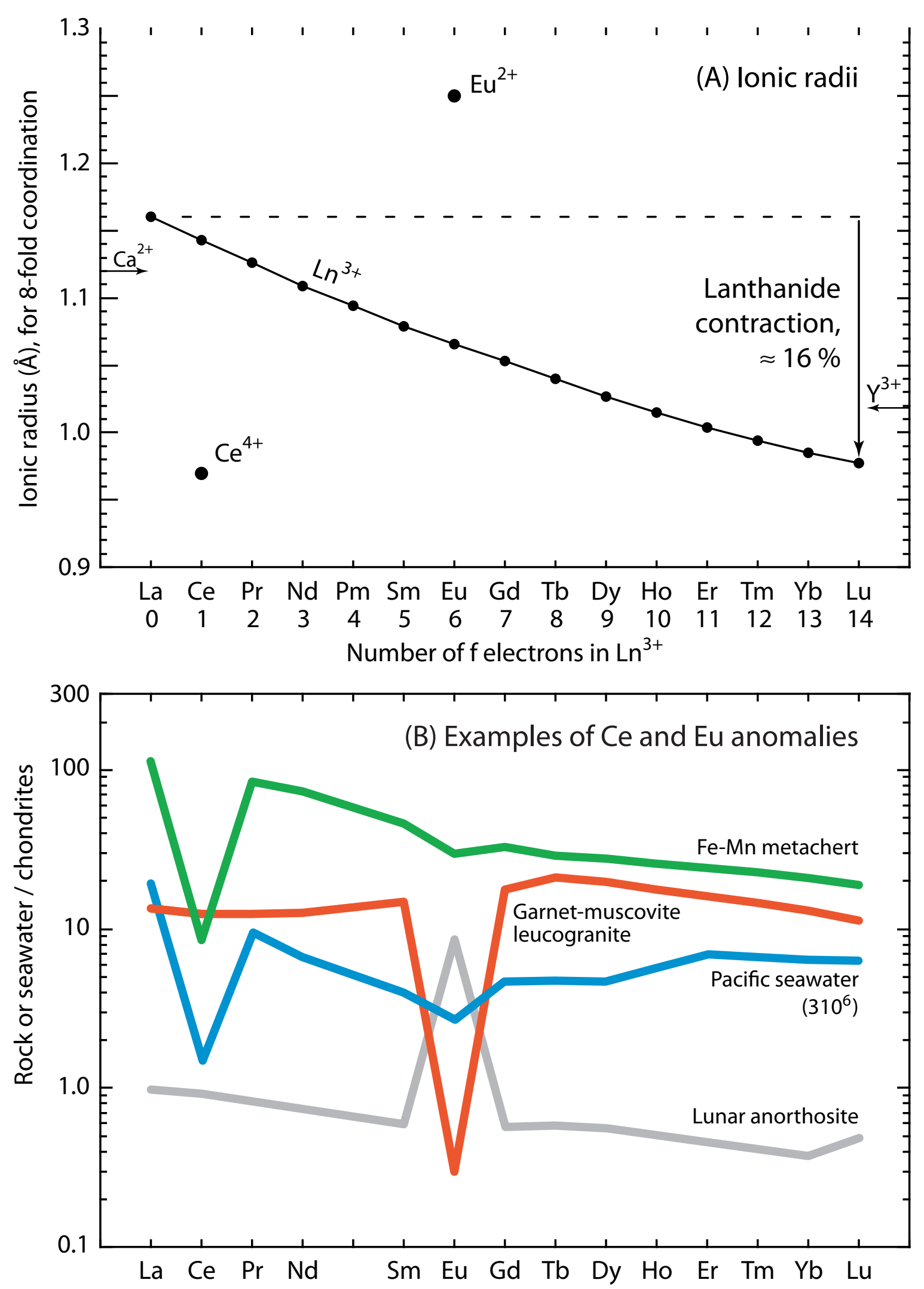

Figure 2. (A) The lanthanide contraction. lonic radii of two other elements are indicated for comparison: $\mathrm{Ca}^{2+}$, the most common major element ion for which the lanthanides readily substitute; and $\mathrm{Y}^{3+}$, geochemically similar to the HREE. $1 \AA$ $=100$ pm. (B) Examples of chondrite-normalized REE spectra with Ce and Eu anomalies: typical Pacific Ocean deep seawater (Taylor and McLennan, 1988); Fe-Mn metachert, Orocopia Schist, Picacho district, southeasternmost California; garnet-muscovite leucogranite, Baboquivari Mountains, southern Arizona; lunar ferroan anorthosite, Hadley-Apennine region, Apollo 15 (Haskin, 1989). The concentrations represented by the seawater pattern have been multiplied by $10^{6}$; that is, in seawater $[\mathrm{La}] \approx 7 \mathrm{pg} / \mathrm{g}$, and $(\mathrm{La})_{\mathrm{cn}} \approx 2310^{-5}$. 


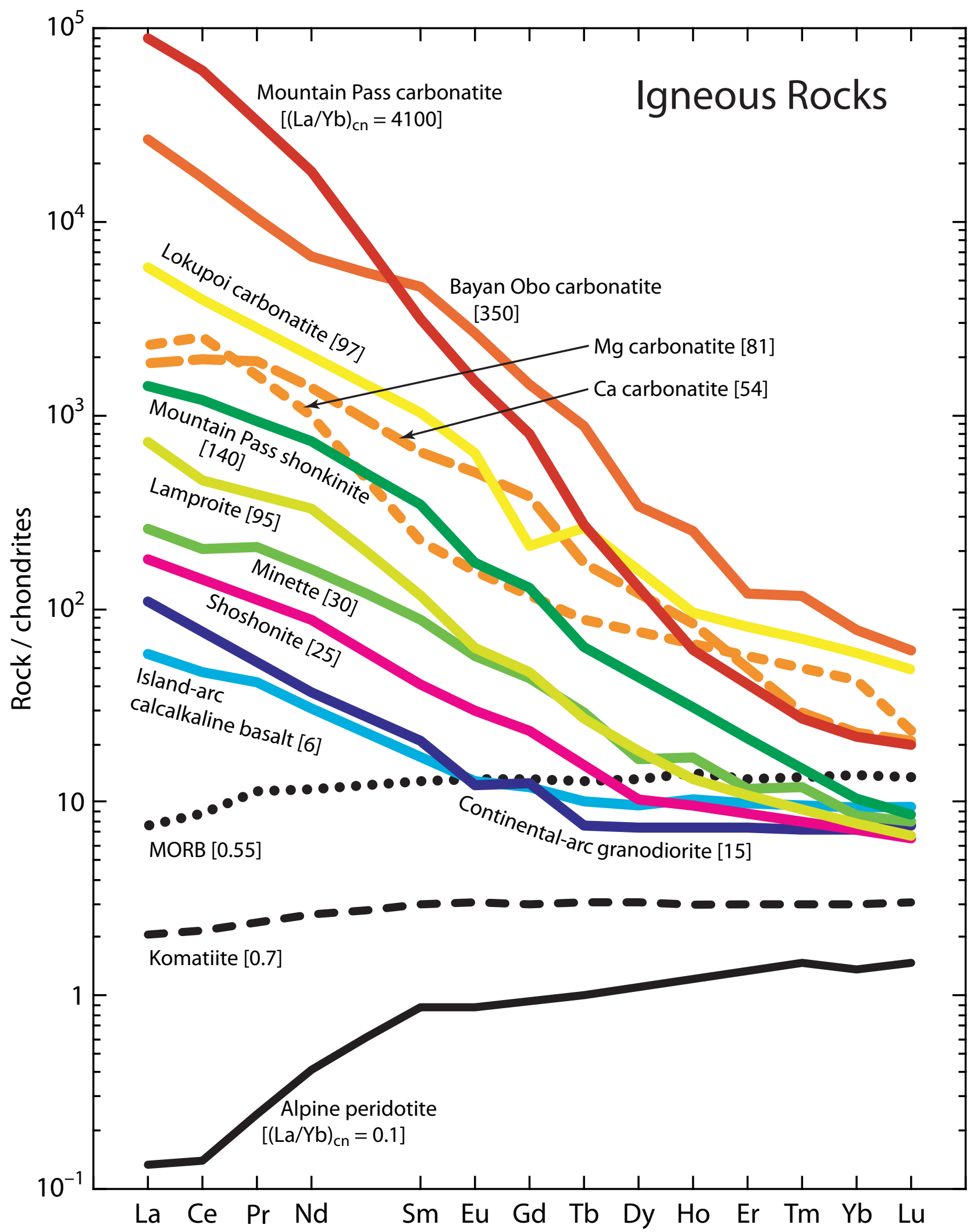

Figure 3. Chondrite-normalized (Table 1; Nakamura, 1974) REE spectra for average (labeled in italic) or representative compositions (labeled in upright type) of several common suites of ultramafic to intermediate, tholeiitic and calcalkaline igneous rocks; and several varieties of continental alkaline igneous rocks, including shonkinite (Table 2) and carbonatite (Table 4) at Mountain Pass (labeled in bold). Number in brackets are chondrite-normalized La/Yb, indicating the degree of LREE-HREE fractionation (Tables 1, 2). Minor irregularities in the HREE portion of some patterns are mostly artifacts owing to analytical difficulties or to averaging of data from analyses reporting different combinations of HREE. Sources of data are given in Haxel (in press 2). 


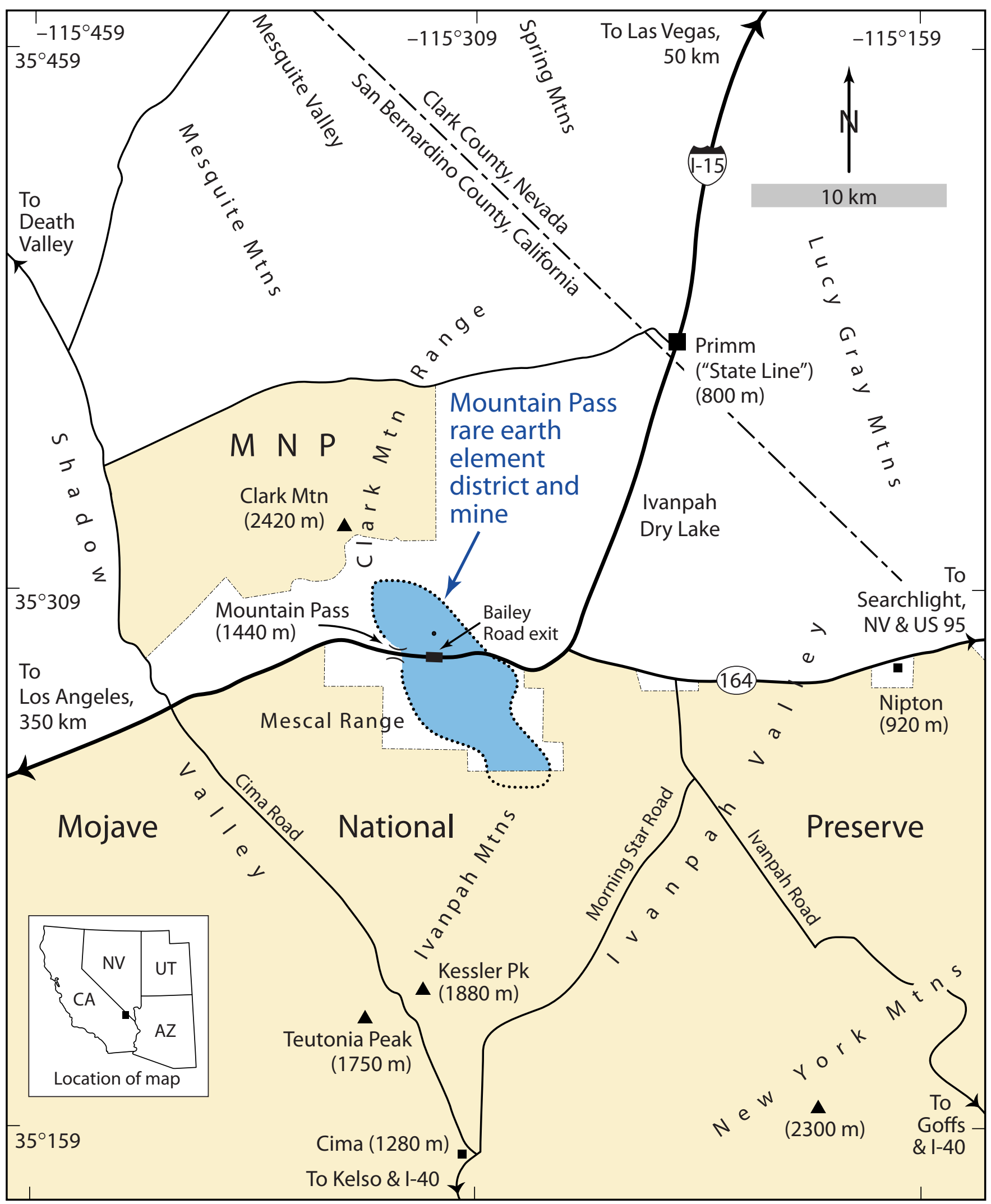

Figure 4. Geographic setting of the Mountain Pass rare earth element district and mine (Figs. 5, 23), upper Mojave Desert, southeast California. Outline of the Mountain Pass district, from Olson and others (1954), is approximate. Physiographic features are labeled in italic, cultural features in upright type. The Mojave National Preserve (www.nps.gov/moja) is part of the National Park system. 


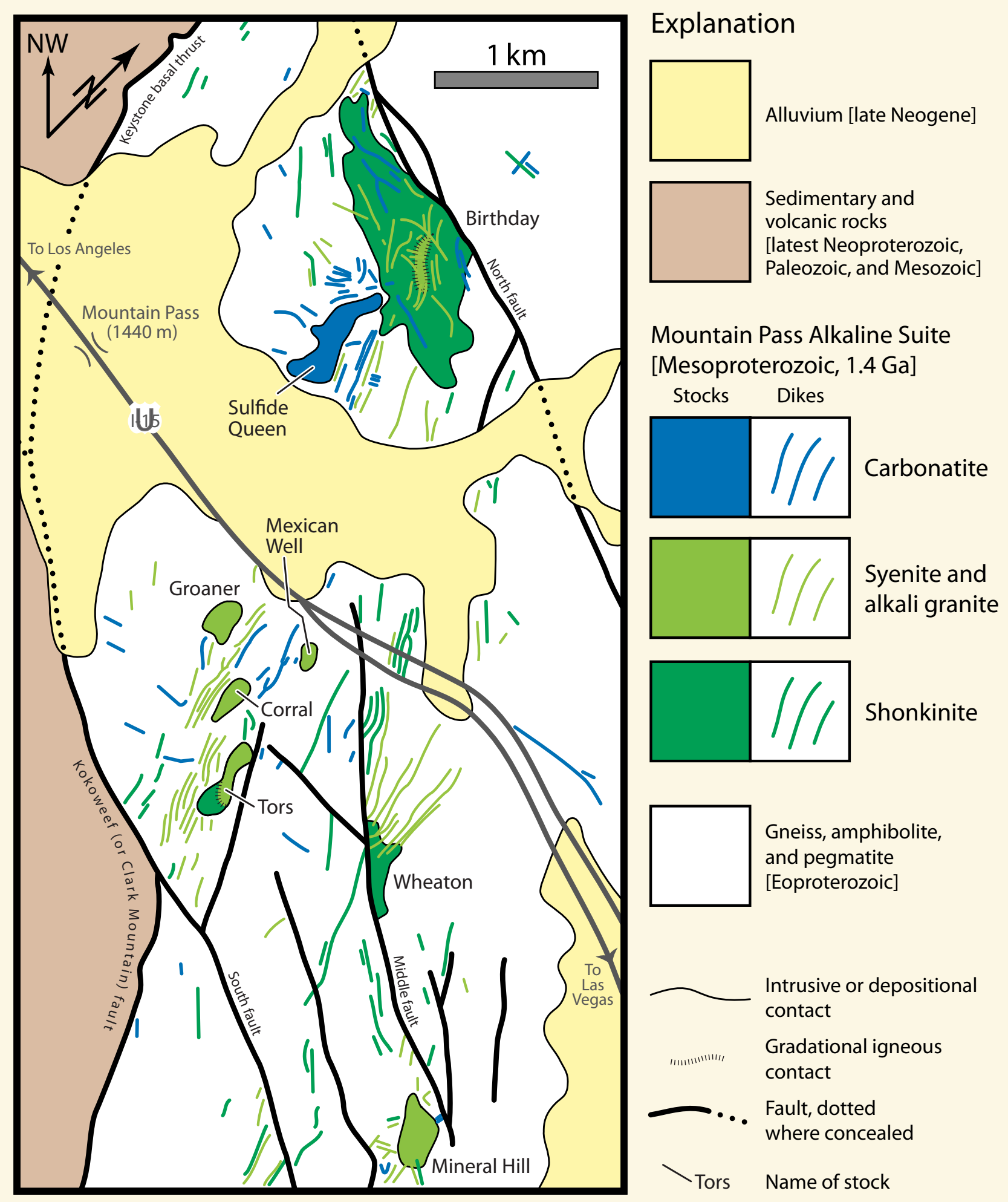

Figure 5. Generalized geologic map of most of the Mountain Pass rare earth element district, southern California (Fig. 4) (after Olson and Pray, 1954; Olson and others, 1954; Burchfiel and Davis, 1971; Evans, 1971; 1.4 Ga age from DeWitt and others, 1987). The district extends $2-3 \mathrm{~km}$ farther south-southeast beyond the area shown on this map. Only a representative minority of the hundreds of shonkinite, syenite, and carbonatite dikes mapped by Olson and others (1954) are shown. Within the Tors and Birthday stocks, some contacts between shonkinite and syenite are gradational, represented schematically by hachured lines. Widespread andesitic and rhyolitic dikes, of Mesozoic or Tertiary age, are not shown. Note that up is northwest. 

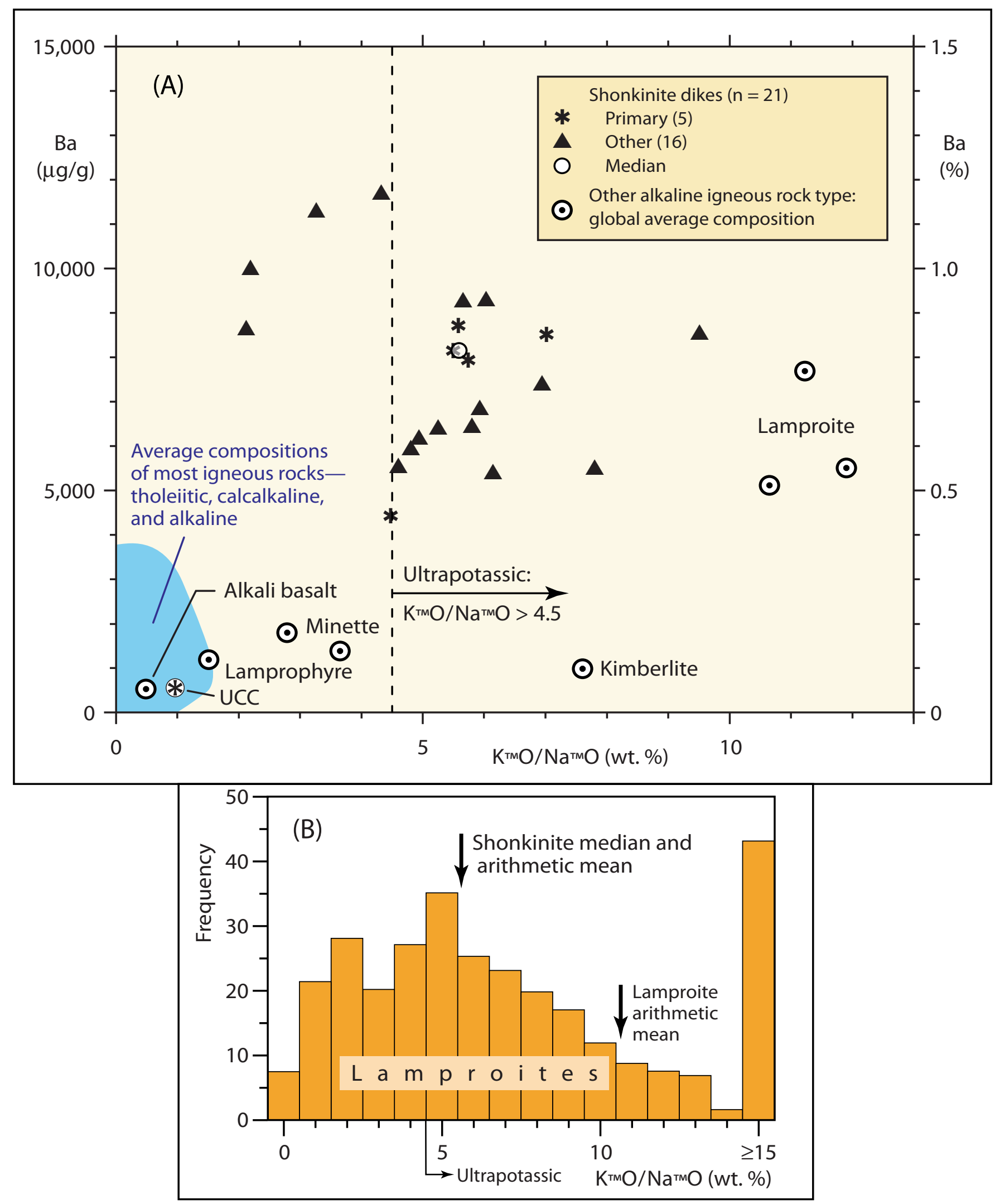

Figure 6. (A) Potassium-sodium ratios and Ba concentrations in shonkinite dikes, compared with global average compositions of most igneous rocks (from numerous literature sources) and of several major types of alkaline igneous rocks (Bergman, 1987; Mitchell and Bergman, 1991; Rock, 1991), and with average upper continental crust (UCC; Taylor and McLennan, 1985). Three averages are plotted for lamproite, and two for minette. (B) Average $\mathrm{K}_{2} \mathrm{O} / \mathrm{Na}_{2} \mathrm{O}$ in the shonkinite dikes compared with the frequency distribution of this ratio in lamproites (after Bergman, 1987, Fig. 20, Table 4). See Table 3, footnote $\{1\}$. 


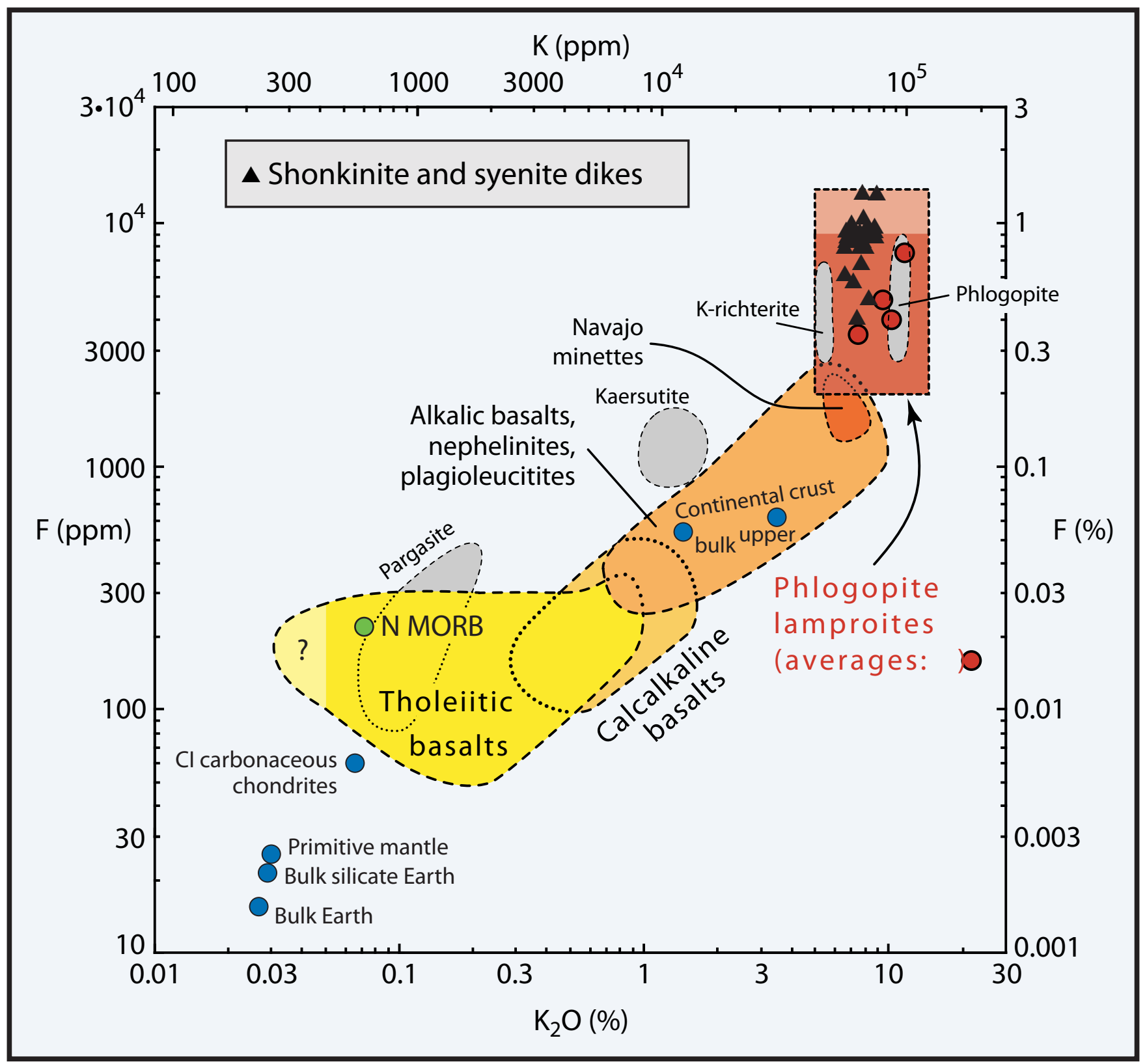

Figure 7. Potassium and fluorine contents of Mountain Pass shonkinite and syenite dikes ( $n=21$; Fig. 10), compared with those of other mafic igneous suites (colored fields), minerals that constitute the principal mantle reservoirs of $\mathrm{K}$ and $\mathrm{F}$ (gray fields), and several major Earth reservoirs or materials (blue dots). Darker red field indicates approximate compositional range of most lamproites; lighter red represents the upper part of the range for a few unusually F-rich lamproites. Bright red dots indicate average compositions for several typical lamproite localities, and for all lamproites. Diagram after Aoki and others (1981); with additional data from Taylor and McLennan (1985); Bergman (1987), Mitchell and Bergman (1991), Rock (1991), Kargel and Lewis (1993), Sun and McDonough (1989), Wedepohl (1995), and several other sources. 


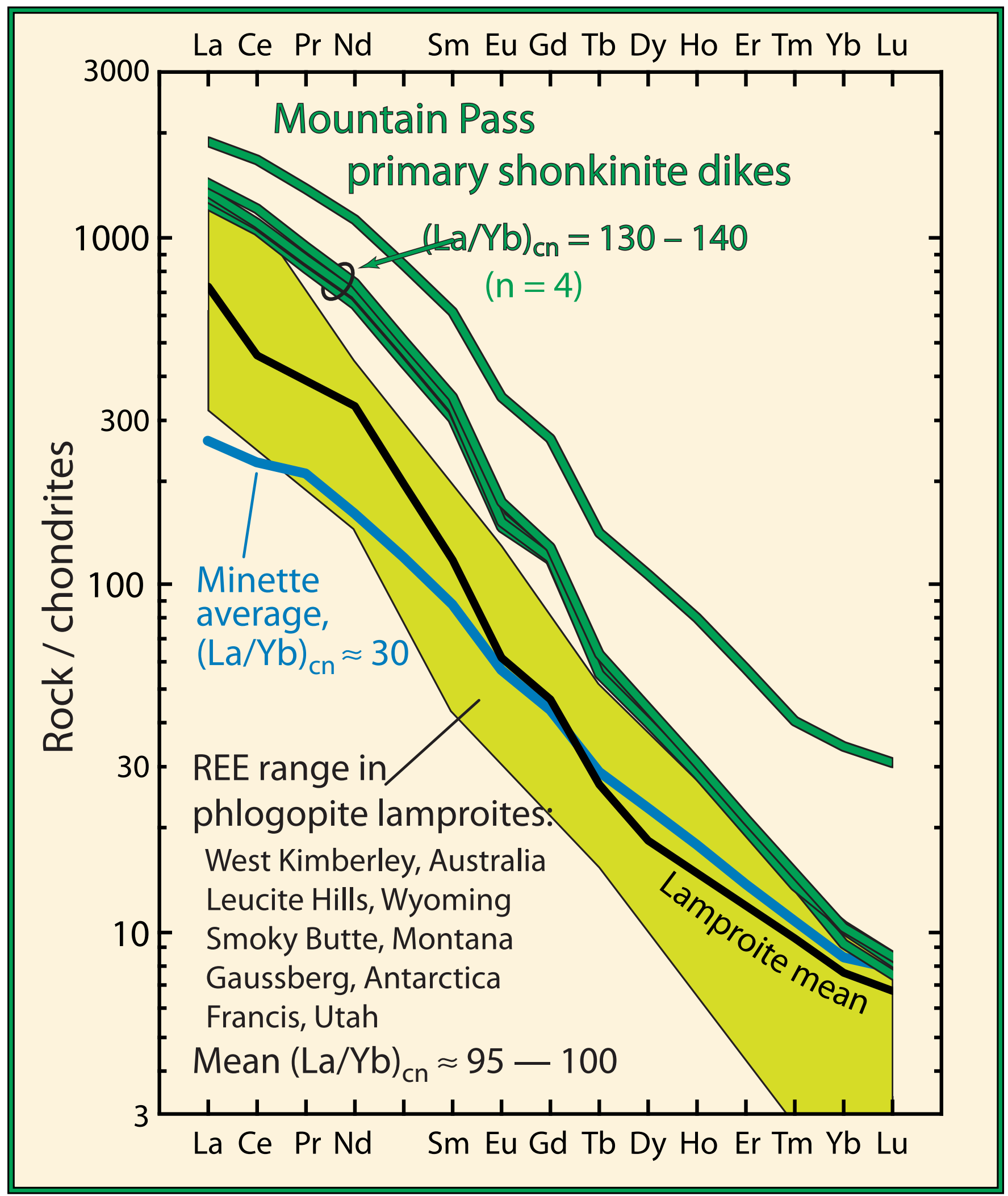

Figure 8. REE spectra of the five most primitive shonkinite dikes (Fig. 10) from Mountain Pass, compared with spectra of lamproites from several classic provinces (Bergman, 1987; Mitchell and Bergman, 1991), and average REE composition of minette (Rock, 1991); chondrite normalized (Table 1; Nakamura, 1974). The four closely clustered shonkinite spectra include the sample presented in Table 2. See also Figure 9. 


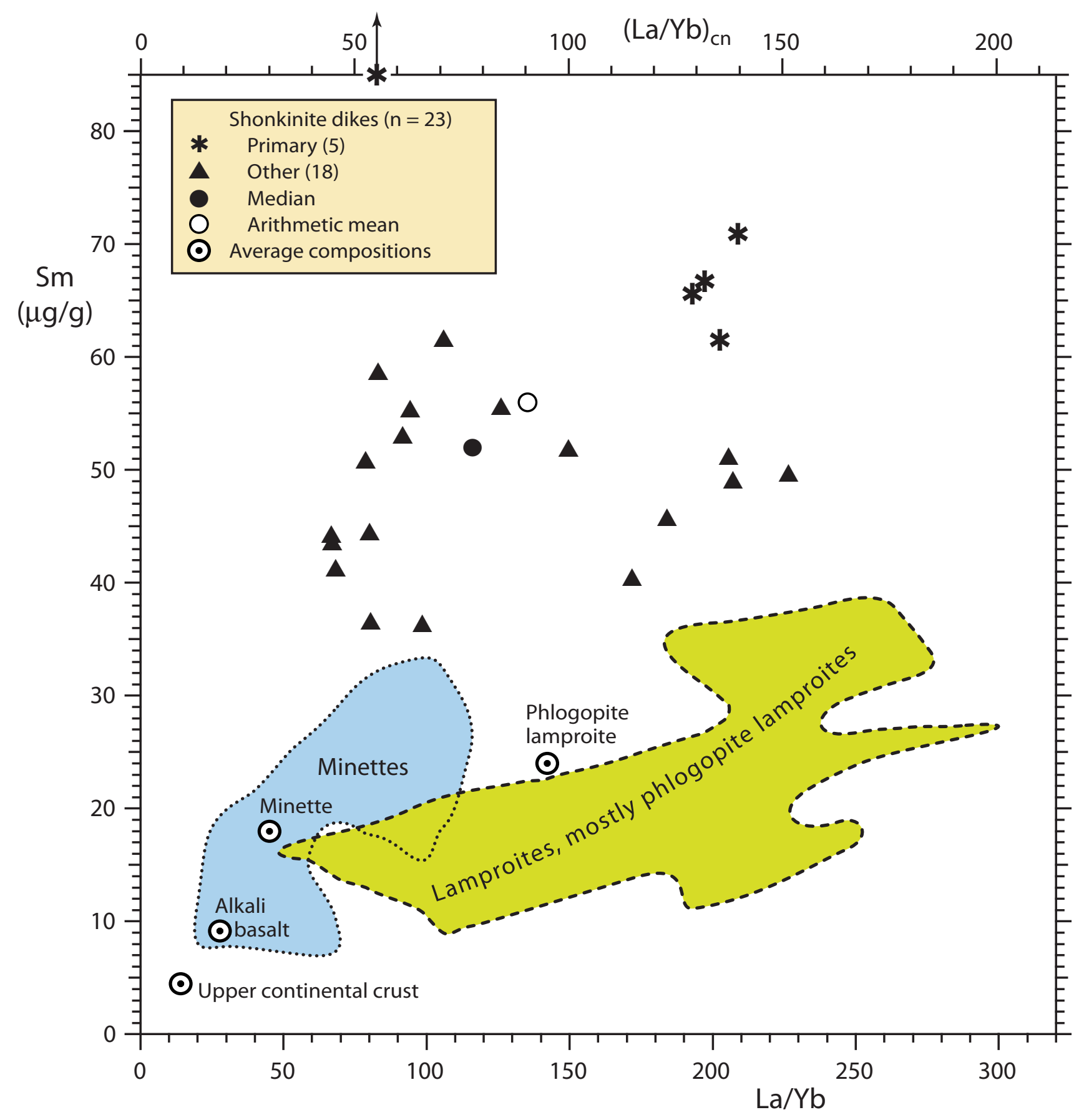

Figure 9. REE systematics of shonkinite dikes from Mountain Pass (including data from Crow, 1984), compared with those of phlogopite lamproites and minettes (generalized from Mitchell and Bergman, 1991, Figs. 7.21, 7.23), and with the average composition of alkali basalt (Bergman, 1987) and upper continental crust (Taylor and McLennan, 1985).

Samarium represents the middle REE (Fig. 8). The lamproite field encompass phlogopite lamproites or all lamproites from nine provinces, excluding one province considered anomalous by Mitchell and Bergman (1991). One Mountain Pass sample, with $\mathrm{Sm}=125 \mu \mathrm{g} / \mathrm{g}$ and $(\mathrm{La} / \mathrm{Yb})_{\mathrm{cn}}=55$ (Fig. 8), plots above the top of the graph. 


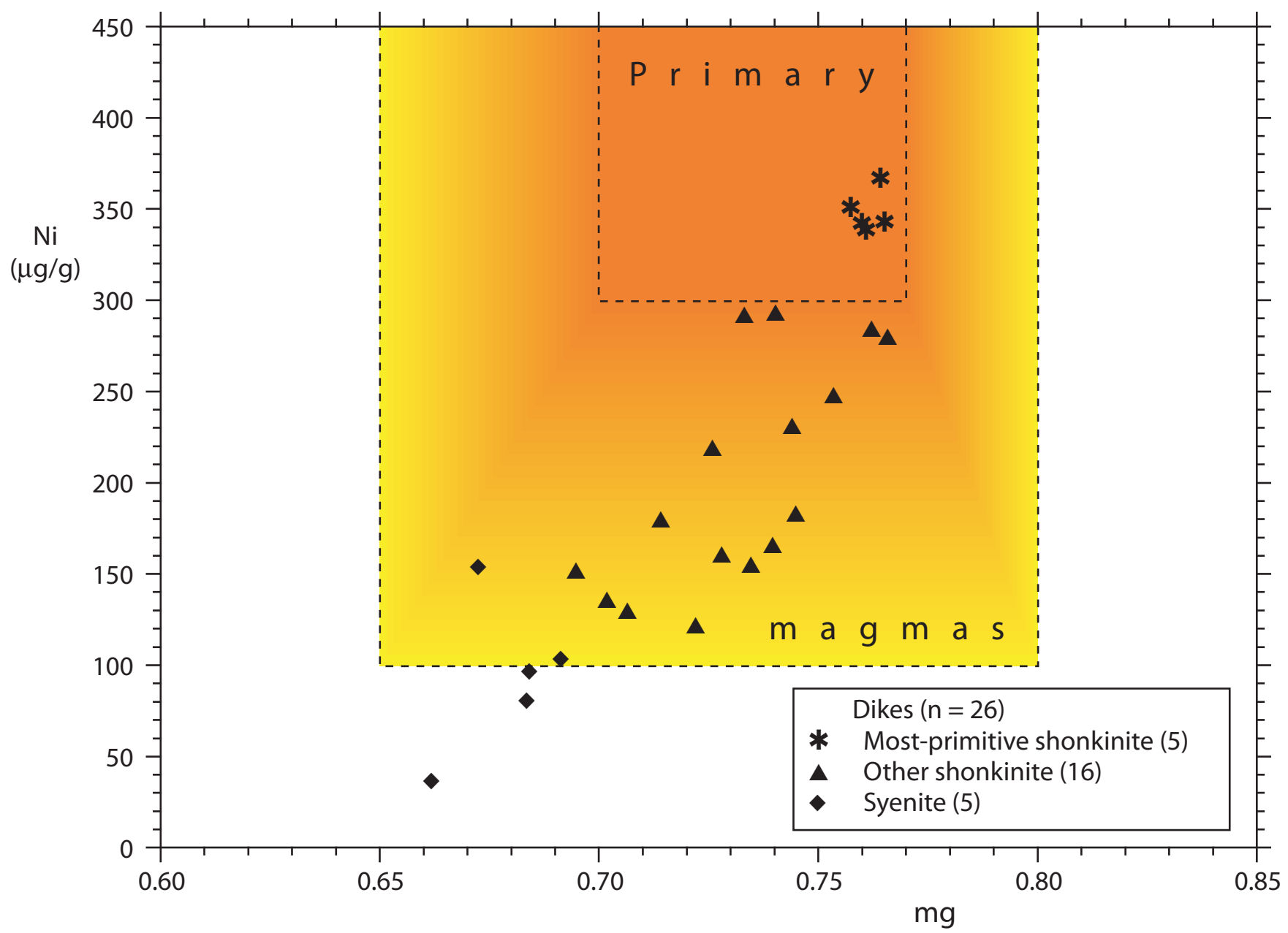

Figure 10. Mg number, $\mathrm{mg}$ (see Table 2 for definition), and Ni concentration in shonkinite and syenite dikes of the Mountain Pass REE district. Orange to yellow rectangles delineate the ranges of values of $\mathrm{mg}$ and Ni commonly considered indicative of primary, mantle-derived magmas (Sato, 1977; Gill, 1981; Rock, 1991; Tatsumi and Eggins, 1995; Nixon and others, 1997). 


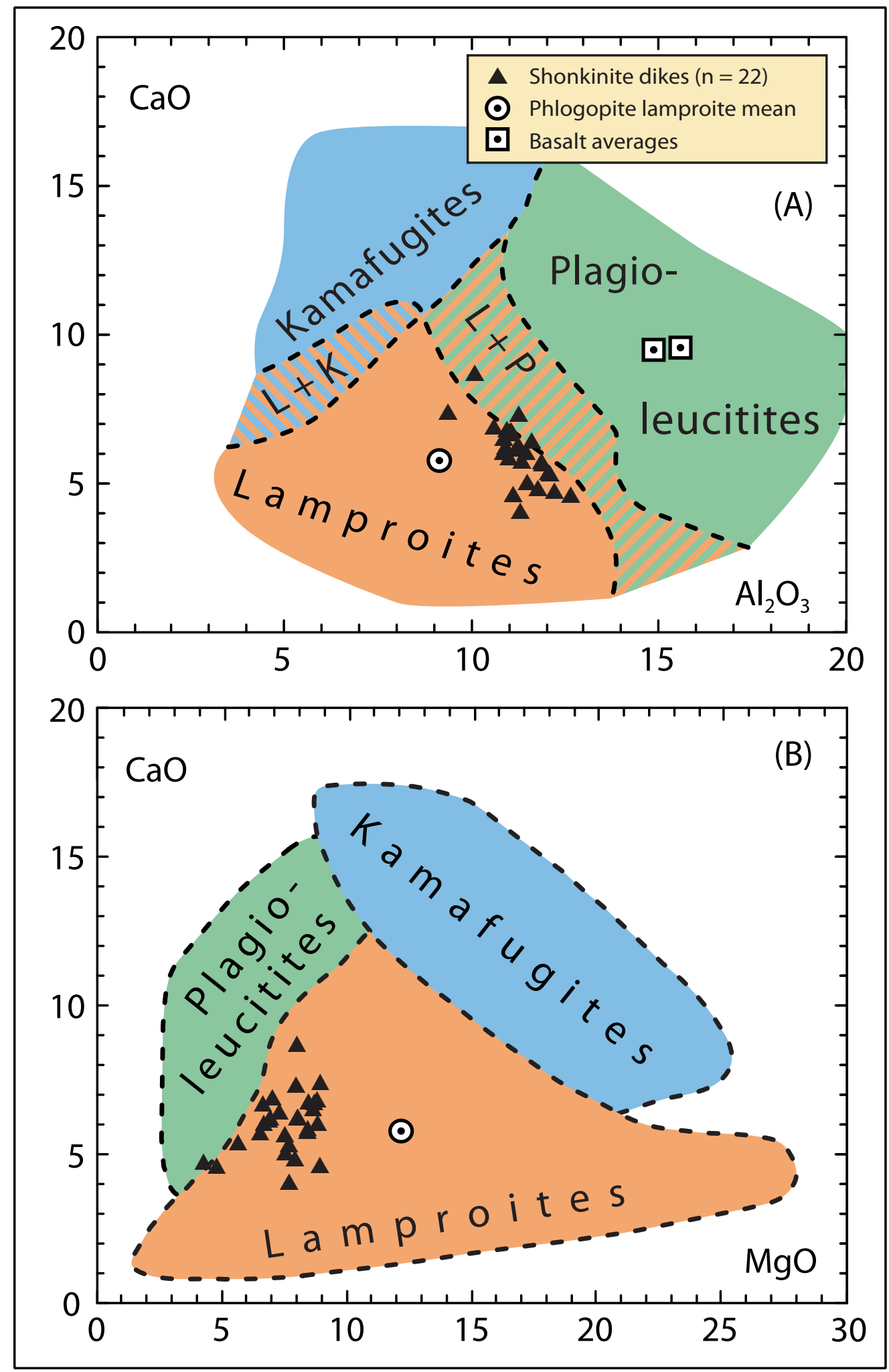

Figure 11. Major element $\left(\mathrm{Al}_{2} \mathrm{O}_{3}, \mathrm{MgO}, \mathrm{CaO}\right)$ compositions of shonkinite dikes, compared with the composi-tional fields of the three major groups of ultrapotassic rocks: lamproites, kamafugites, and plagioleucitites (generalized from Foley, 1987), and with the mean composition of lamproites and alkali basalts (Bergman, 1987) and basalts (LeMaitre, 1976). In the upper graph, " $\mathrm{L}+\mathrm{K}$ " and " $\mathrm{L}+\mathrm{P}$ " indicate the overlap of the compositional field of lamproites with those of kamafugites and plagioleucitites, respectively. 


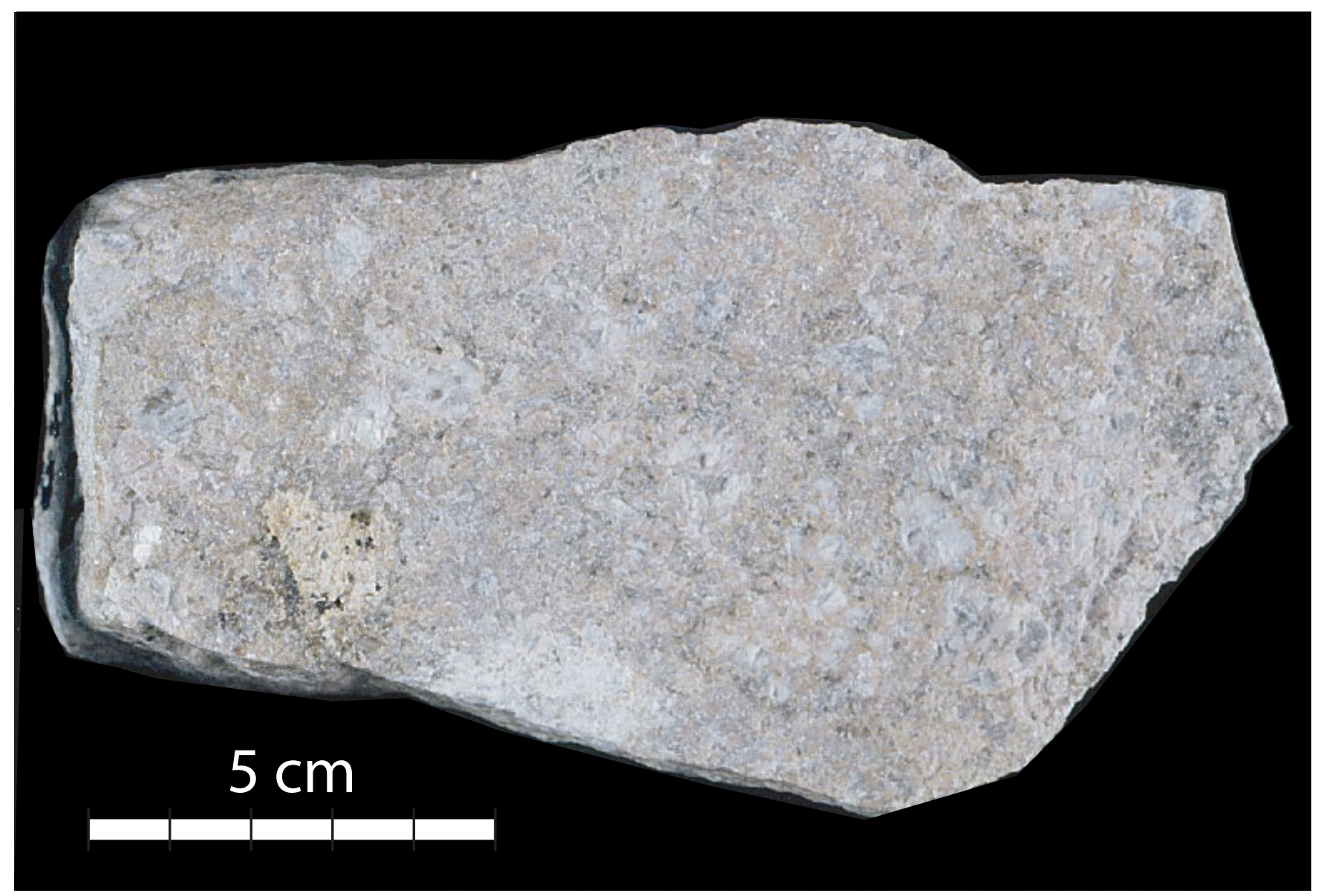

Figure 12. Sövite (calcite carbonatite) from the Sulfide Queen stock, Mountain Pass. Abundant, tabular to irregular, light-gray to cream phenocrysts of barite, the largest 1-1.5 cm across, are surrounded by a pinkish-tan to light-salmon, medium-grained matrix composed of calcite, barite, and bastnäsite. Matrix calcite and barite are difficult to distinguish, and the bastnäsite crystals too small to see, in hand specimen. The chemical composition of a similar sövite is shown in Figure 13 and Table 4. The yellowish object in the lower left is a small, altered xenolith. The whitish area along the lower edge is a percussion (hammer) mark. As printed here, the specimen is imaged approximately actual size. 


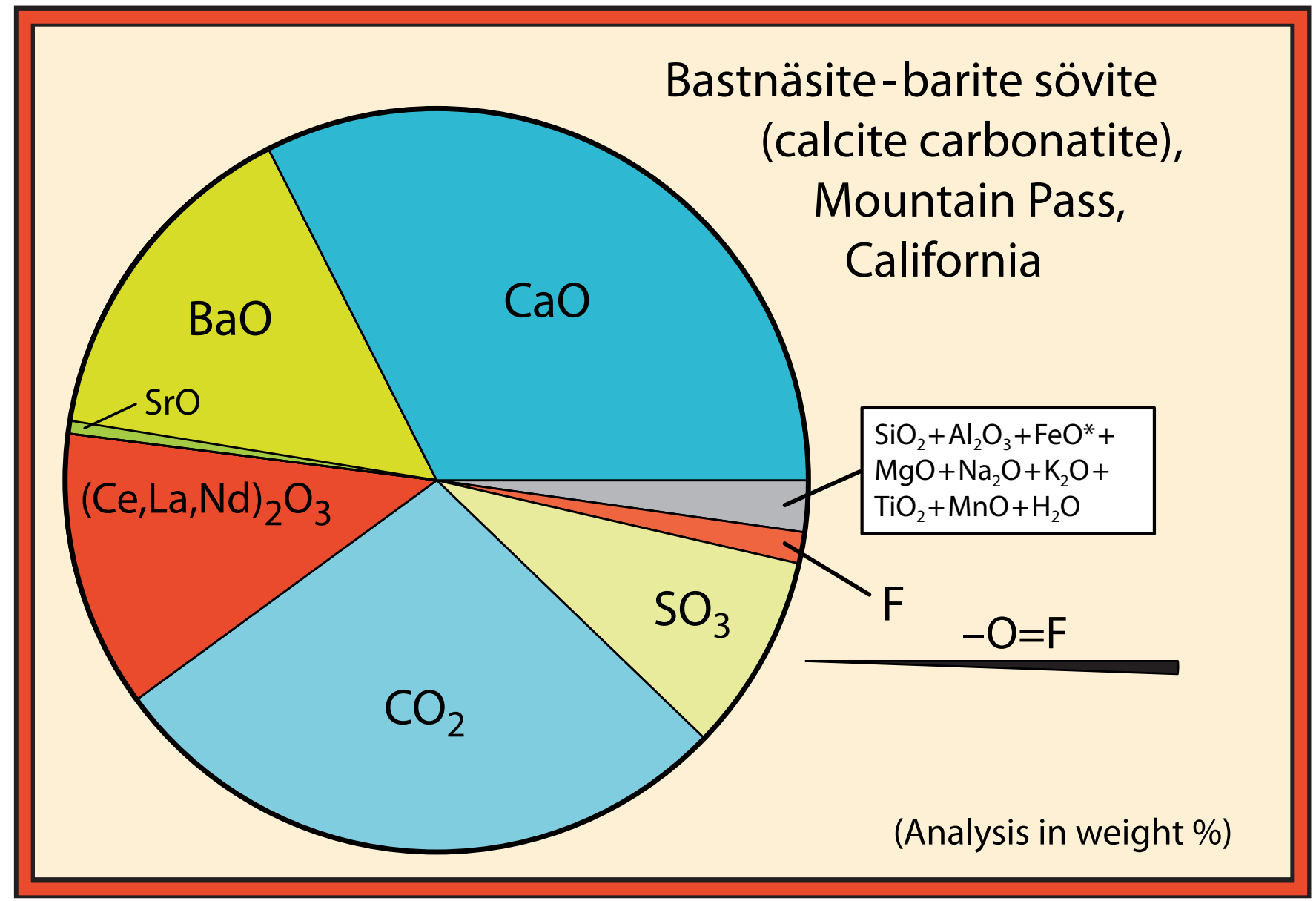

Figure 13. Proportions, by mass, of major and minor constituents of bastnäsite-barite sövite (Fig. 12), Mountain Pass. The proportion of individual lanthanides and $\mathrm{Y}$ within the $\mathrm{Ln}_{2} \mathrm{O}_{3}$ component is shown in Figure 18. The black sector labeled " $-\mathrm{O}=\mathrm{F}$ " represents grams of $\mathrm{O}$ stoichiometrically equivalent to the grams of $\mathrm{F}$ in the analysis; if the analysis were tabulated, this value would be subtracted from the sum of the oxides and $\mathrm{F}$ to yield the analytical total. 


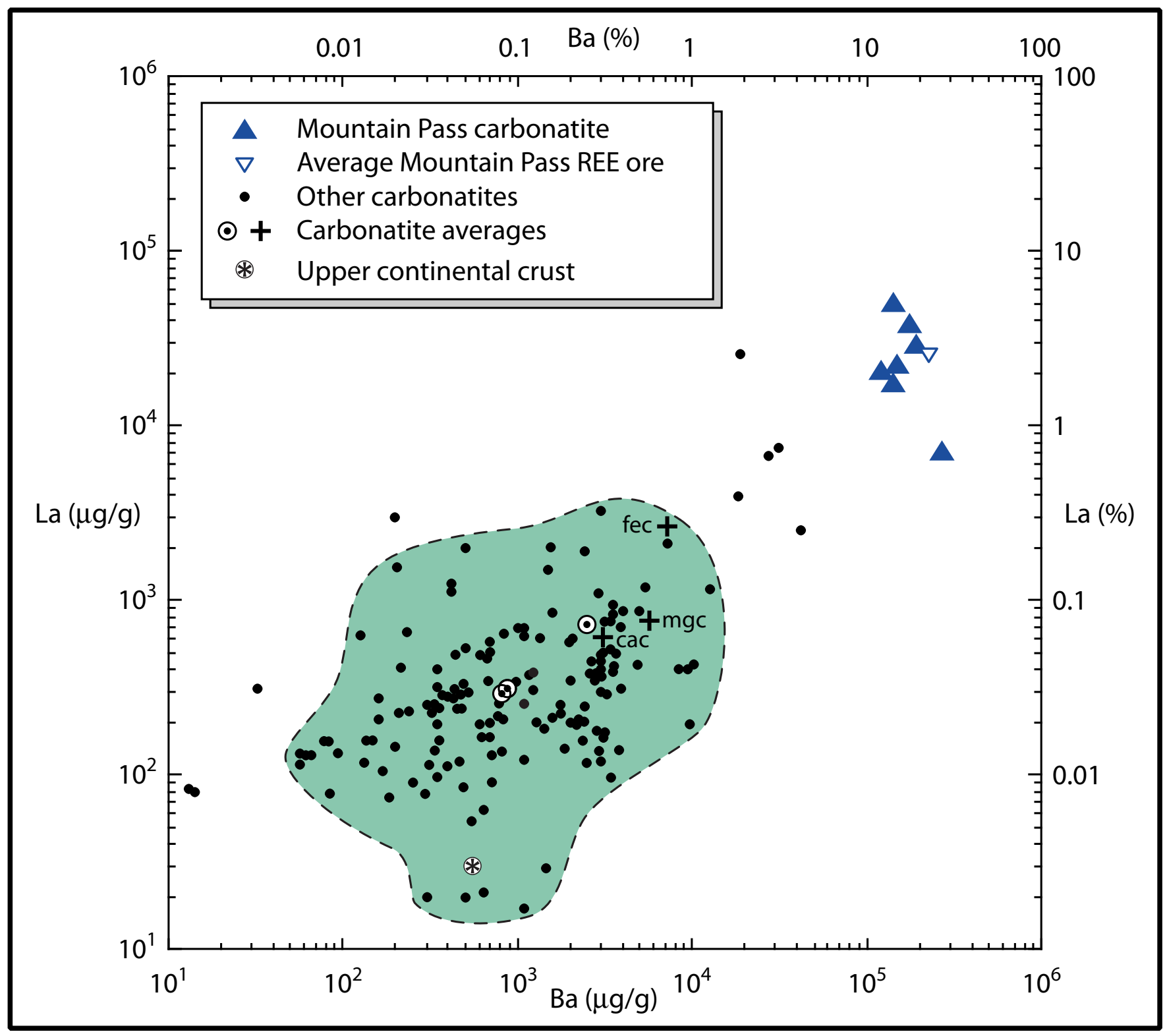

Figure 14. Concentration of Ba and La in the LREE-rich carbonatite at Mountain Pass, California compared with other, ordinary carbonatites. Small dots represent 161 analyses of carbonatites, from five continents (data from Nelson and others, 1988; Bell, 1989; and several other sources); 94 percent of these data plot within the green area. The two overlapping encircled dots symbols represent the geometric mean and median of these data (excluding Mountain Pass); the third such symbol is the arithmetic mean. The three equant crosses represent the global average composition (presumably the arithmetic mean) of $\mathrm{Ca}-, \mathrm{Mg}-$, and Fe-carbonatites (labeled respectively cac, $\mathrm{mgc}$, fec) from Woolley and Kempe (1989). See also Figure 15. 


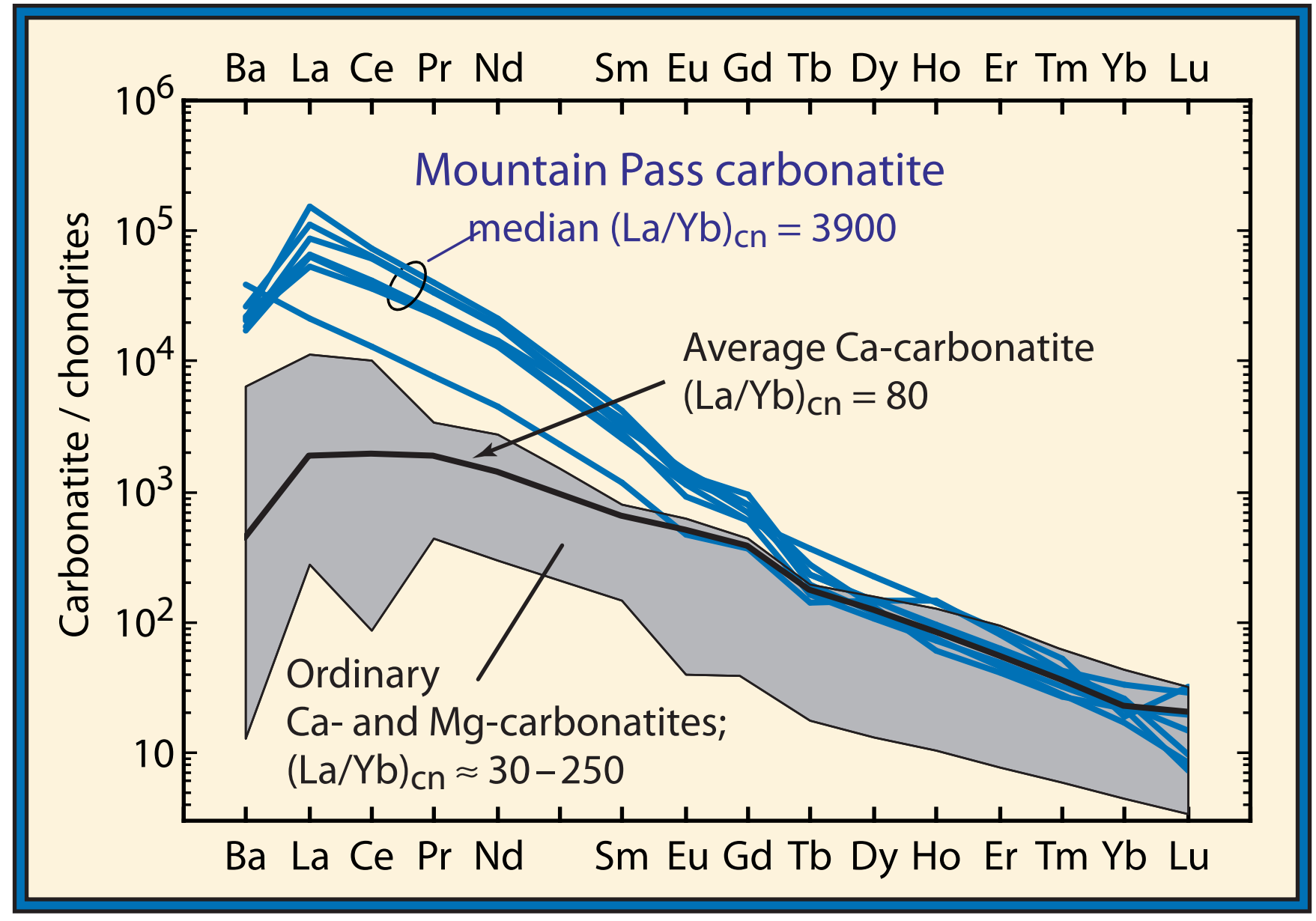

Figure 15. Extended REE spectra (lanthanides plus Ba) of Mountain Pass carbonatite (including one analysis from Johnson and Sisneros, 1982), compared with ordinary carbonatites (Woolley and Kempe, 1989); chondrite normalized (Table 1; Nakamura, 1974). See also Figures 3, 13, and 14. 


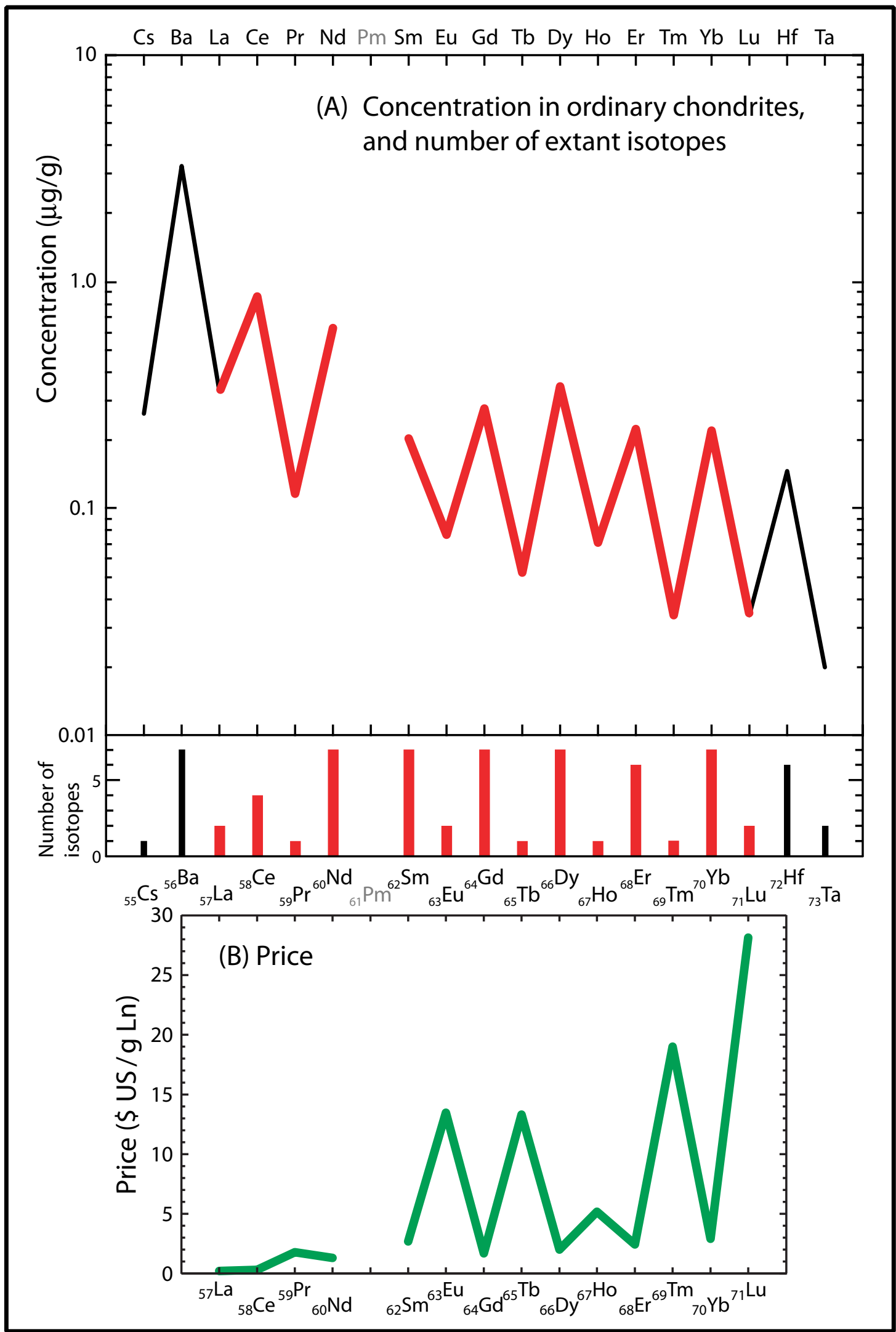

Figure 16. (A) Average concentrations of lanthanides in ordinary chondrites (Table 1; Nakamura, 1974) and the adjacent elements Cs, Ba, Hf, and Ta in C1 chondrites (Anders and Grevesse, 1989); and number of extant (stable or radioactive but long-lived) isotopes. Yttrium is monoisotopic ( $\left.{ }_{39} \mathrm{Y}\right)$, with chondritic abundance $2.0 \mu \mathrm{g} / \mathrm{g}$. (B) Comparison of the prices $(\$ / \mathrm{g})$ of the lanthanides, based upon prices for lanthanide oxides at 99.9 percent purity in $25 \mathrm{~g}$ quantities (Sigma-Aldrich Company, 2002). The price of $Y$ is approximately the same as that of $\mathrm{Pr}$. 


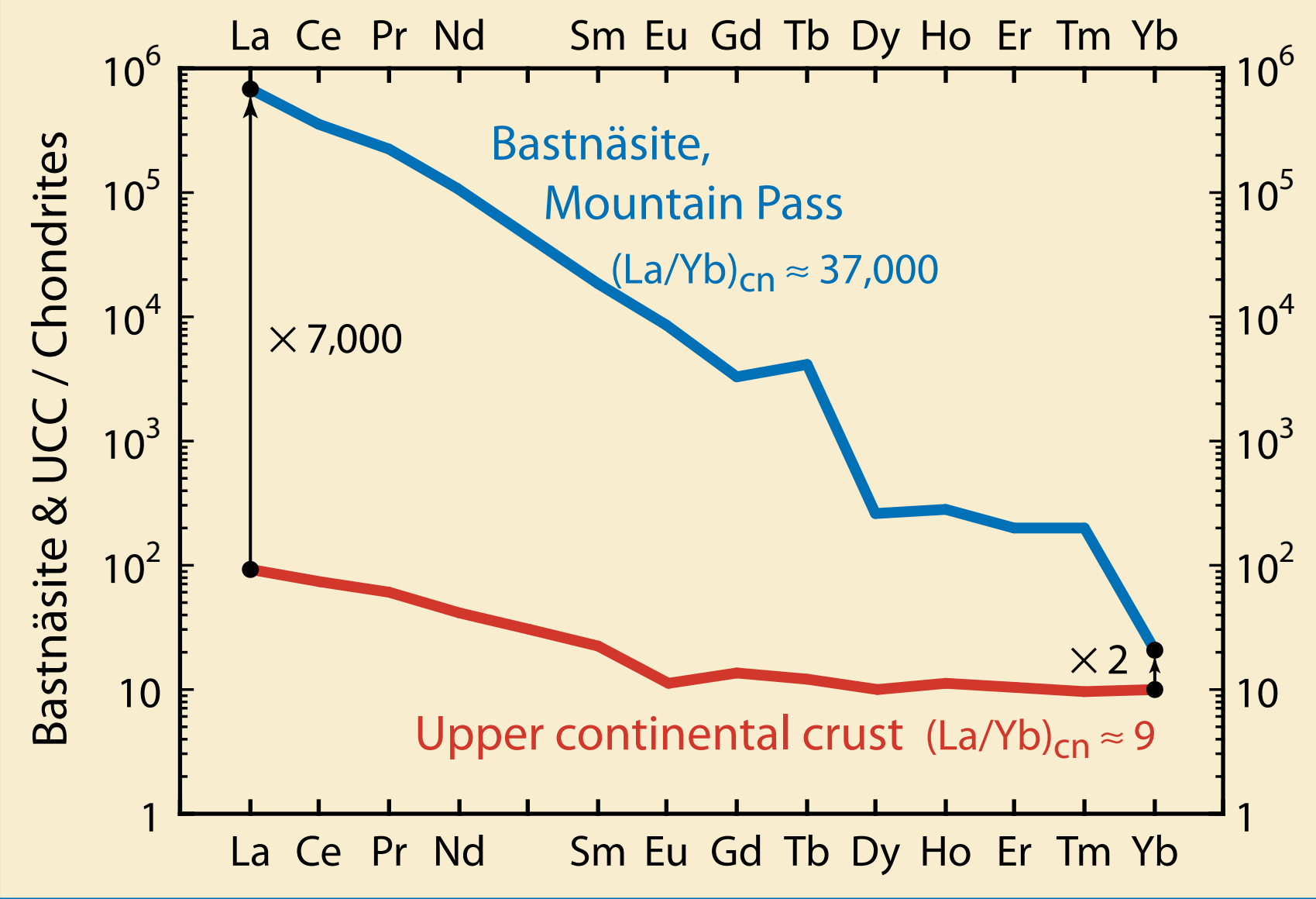

Figure 17. REE spectra of bastnäsite from the Mountain Pass carbonatite (Mariano, 1989b), compared with average upper continental crust (Taylor and McLennan, 1985); chondrite normalized (Table 1; Nakamura, 1974). 


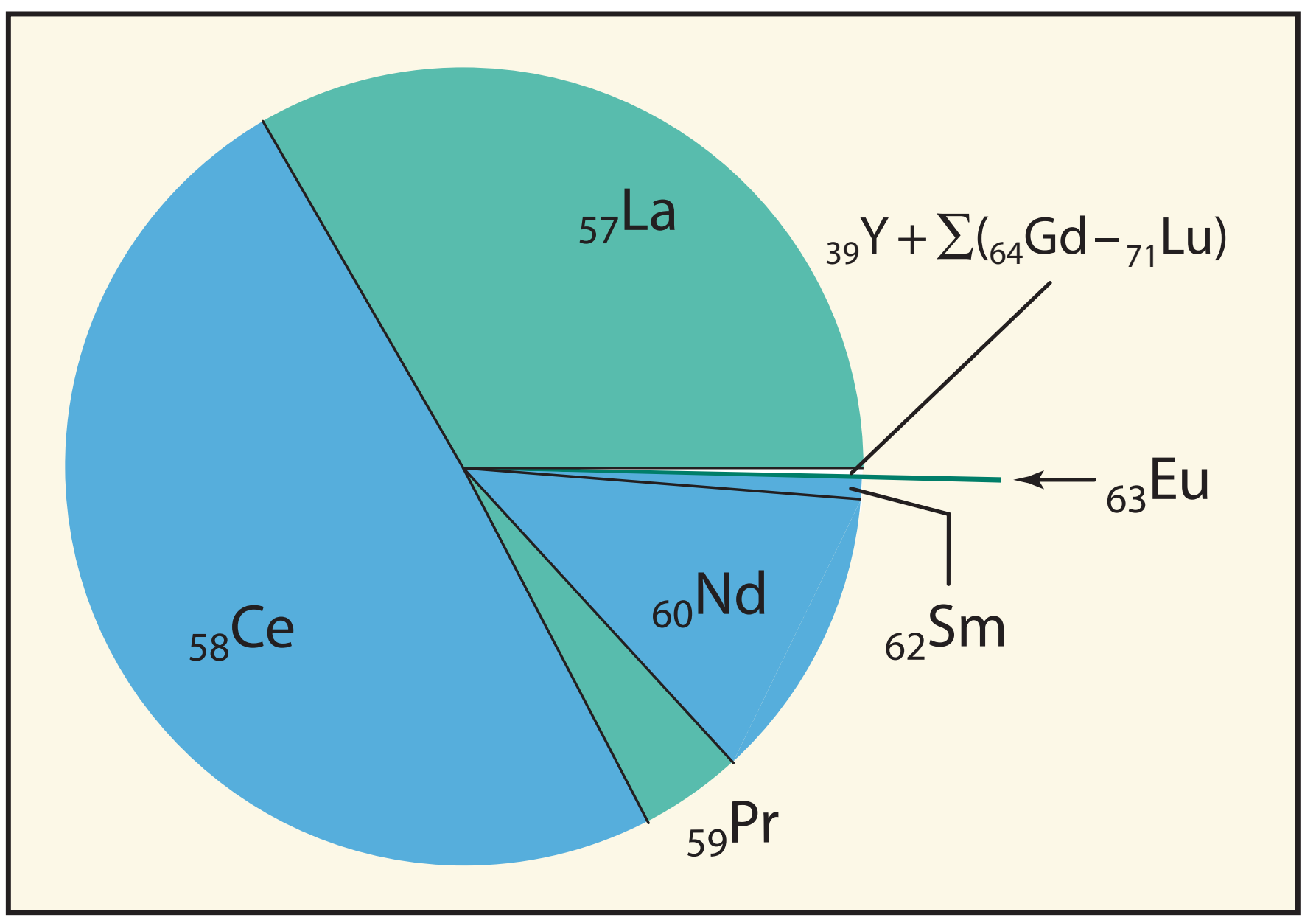

Figure 18. Proportions of individual REE in bastnäsite ore from Mountain Pass (Table 4; Johnson and Sisneros, 1982; Kilbourn, 1993). Yttrium plus all lanthanides from Gd through Lu total only 0.3 percent, most of which comprises just $Y$ and Gd. Europium makes up only about 0.1 percent of the REE content of the ore. Green and blue sectors represent lanthanides $\left({ }_{z} \mathrm{Ln}\right)$ of odd and even atomic number, respectively. The even-Z lanthanides $\mathrm{Nd}$ and Sm adjoin because the intervening odd-Z lanthanide, ${ }_{61} \mathrm{Pm}$, has zero abundance (Table 1; Figs. 1, 16). For comparison of Mountain Pass ore, Ce-dominated, with a Chinese ion-adsorption ore, Y-dominated, see Haxel and others (2002, Fig. 6). See also Figure 20. 


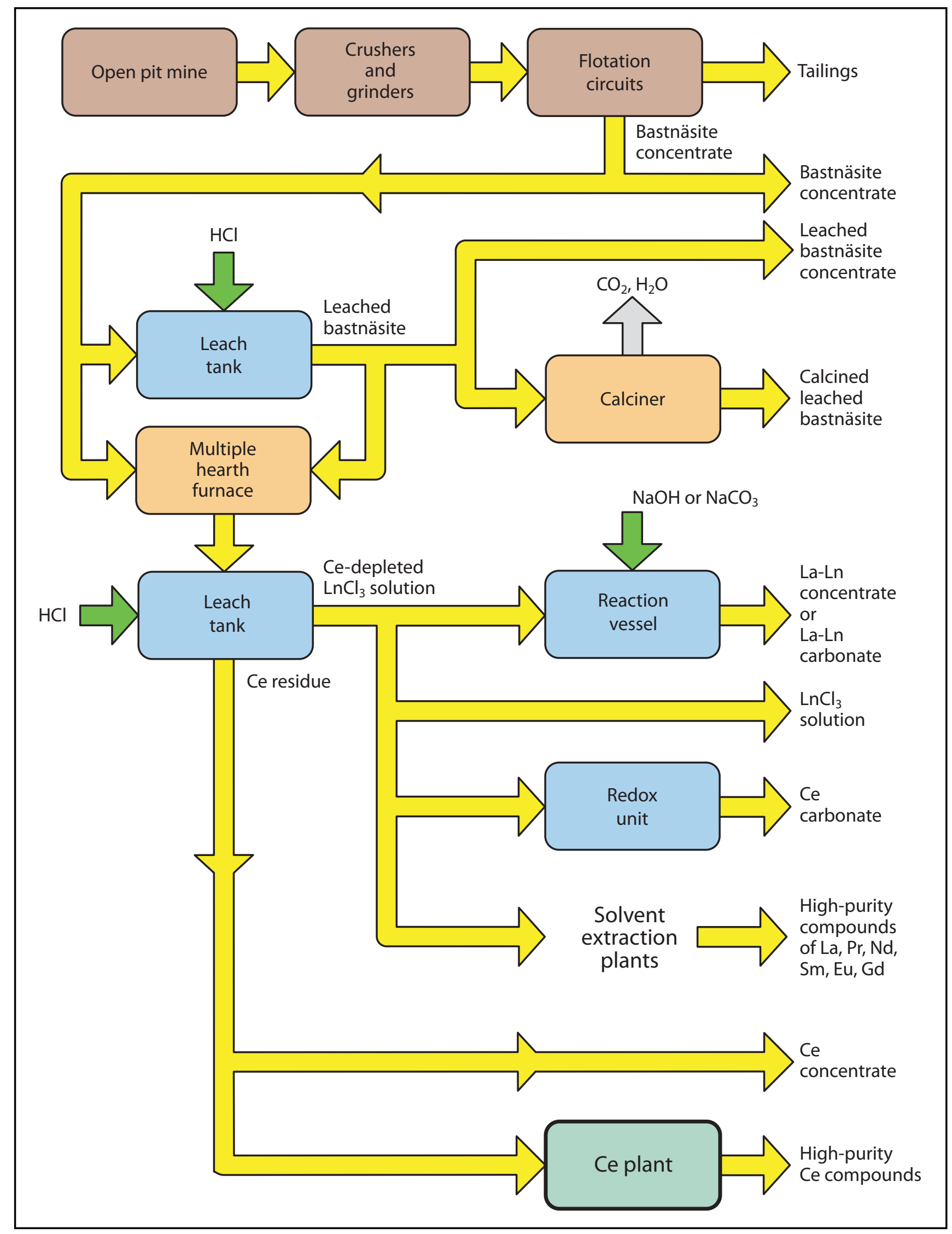

Figure 19. Schematic flow diagram of REE ore processing at Mountain Pass, as outlined in the text. Bold type indicates final products or groups of products (Fig. 20). 


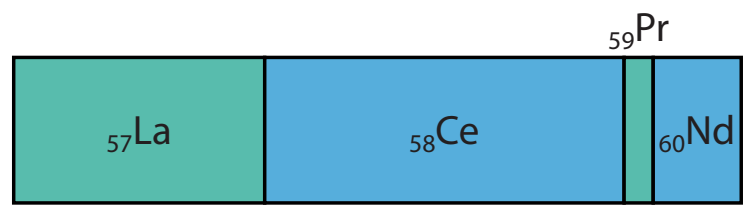

Bastnäsite concentrate, leached bastnäsite concentrate, calcined leached bastnäsite

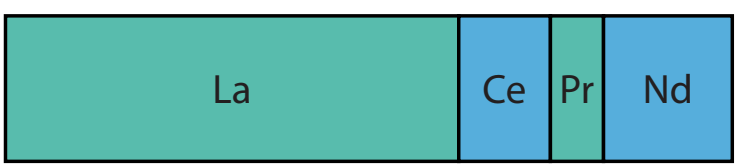

$\mathrm{LnCl}_{3}$ solution, La-Ln concentrate

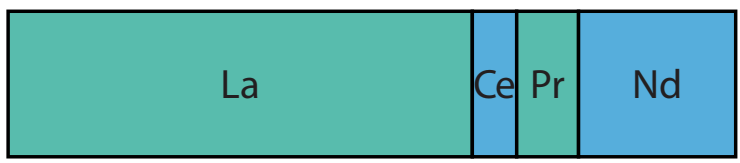

La-Ln carbonate

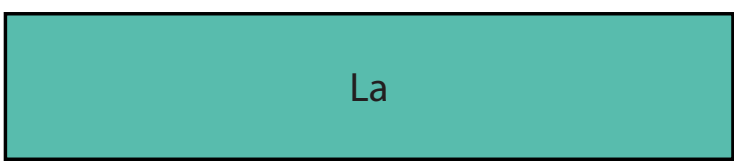

La oxide

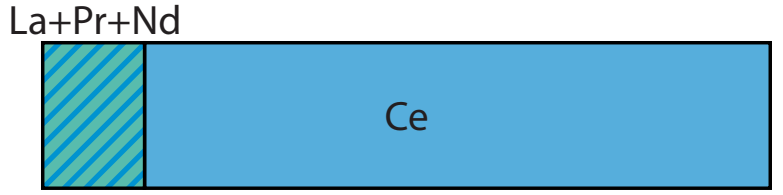

Ce concentrate

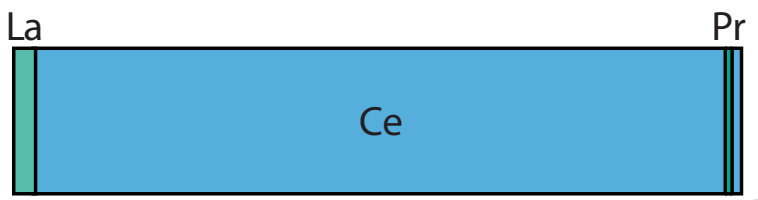

Ce carbonate $96 \%$, Ce oxide $96 \%$

$\mathrm{Ce}$

Ce oxide $99 \%$

Figure 20. Approximate proportions of the four lightest lanthanides in several bastnäsite, La, and Ce products (Fig. 19) from Mountain Pass (after Kilbourn, 1993; with recent data from www.molycorp.com, consulted in May 2004 and February 2005). These products typically contain less than $\approx 1$ percent combined total of lanthanides beyond Nd plus Y. Chief non-lanthanide elemental constituents are $\mathrm{H}, \mathrm{F}, \mathrm{Na}, \mathrm{Si}, \mathrm{P}, \mathrm{Ca}, \mathrm{Fe}, \mathrm{Mn}, \mathrm{Sr}, \mathrm{Ba}$, and $\mathrm{Pb}$; at concentrations ranging from $\sim 5$ weight percent to $20 \mu \mathrm{g} / \mathrm{g}$. Green and blue represent lanthanides of odd ( $\mathrm{La}, \mathrm{Pr}$ ) and even (Ce, $\mathrm{Nd}$ ) atomic number, respectively (Fig. 18). 


\section{Principle of solvent extraction (SX): separation of La from heavier lanthanides ( $\mathrm{Pr}+$ )}

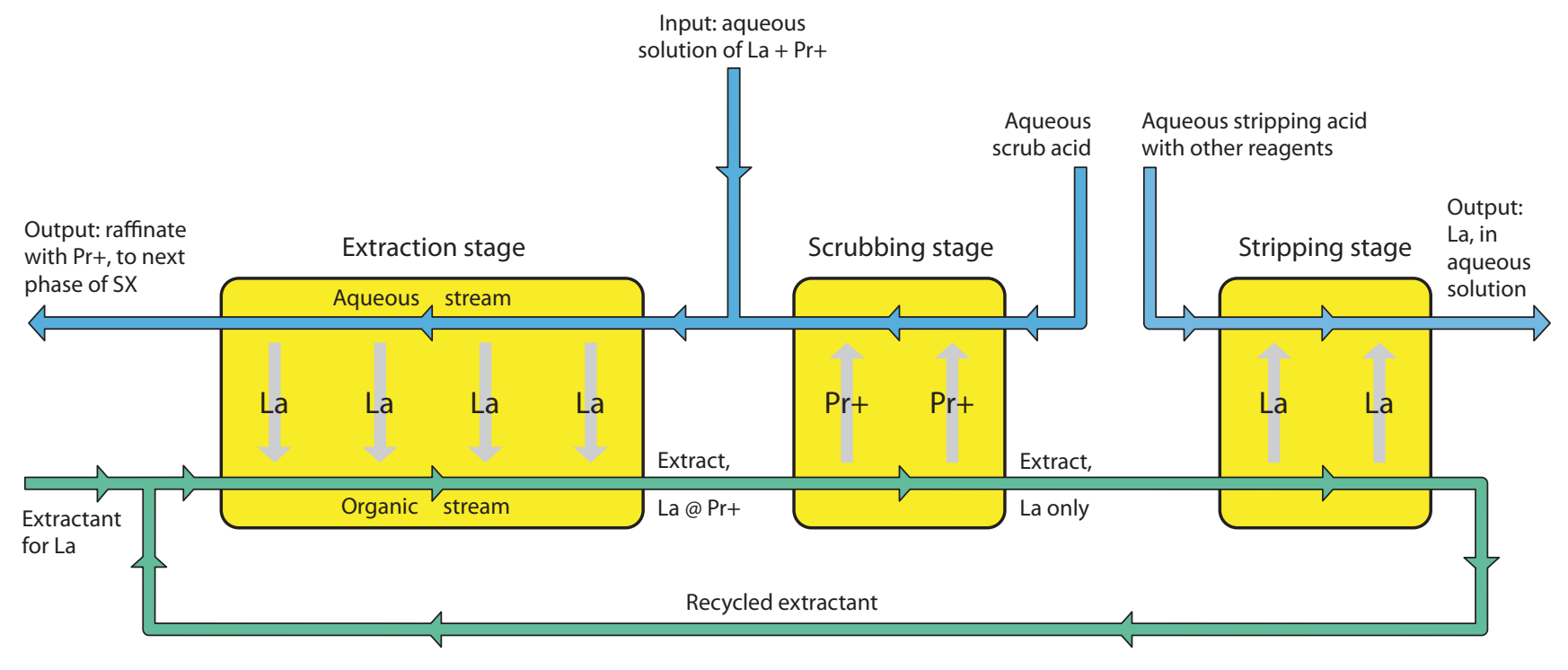

Figure 21. Schematic illustration of the principle of liquid-liquid solvent extraction (SX), as implemented in three stages: extraction, scrubbing, and striping (after Kaczmarek, 1981; Hedrick and Haxel, in press). Separation of La from Pr plus heavier lanthanides $(\mathrm{Pr}+)$ is shown as an example. That is, "Pr+" designates $\mathrm{Pr}+\mathrm{Nd}+\mathrm{Sm}+\ldots$ (Ce having been removed earlier: Fig. 19). The two immiscible liquids used in SX processing of the REE are an aqueous solution, typically Ln chloride or nitrate; and an organic solvent, such as tributyl phosphate, in a diluent, such as kerosene. Although the lanthanides being separated are soluble in both liquids (organic and aqueous), by convention the organic phase is called the solvent or extractant, the solvent bearing the desired lanthanide solute (in this example La) is called the extract, and the residual aqueous phase containing the other lanthanides $(\mathrm{Pr}+)$ the raffinate.

As preferential partitioning of a desired lanthanide, here La, into the extractant is slight, the efficiency of SX is increased through the use of two stages, extraction and scrubbing. In the main, extraction stage, conditions are such that La partitions into the extractant. At the output of the extraction stage, the extract has a significant residual concentration of $\mathrm{Pr}+$. These impurities are removed in the scrubbing stage, where the extract is brought into contact with a scrub acid. Conditions (chiefly $\mathrm{pH}$ ) are established such that the impurities enter the aqueous phase, while La remains largely in the extractant. The extract is then sent to a stripping stage, where La is recovered; and the aqueous phase passed back to the extraction stage. The extractant is recycled from the stripping stage back to the extraction stage.

Many successive cycles of SX are required to produce a pure ( $99.0-99.99 \%)$ solution of a single lanthanide. The efficacy of SX in industrial-scale separation of the lanthanides owes to its implementation as a multi-stage, continuous-flow, countercurrent process. In this technique, a number of SX cells $(\approx 50-1000)$ are linked in series. The aqueous and organic liquids are circulated through the cells in opposite directions. Flow is made turbulent in order to maximize contact between the immiscible liquids and promote approach to equilibrium partitioning of lanthanides between these two phases. Each SX cell has a mixer or stirrer. Mixing is periodically interrupted to allow the immiscible fluids to settle and separate. This alternation of mixing and settling is repeated many times in each cell. The whole flow process continues until the concentration in the extractant of the lanthanide being recovered is as large as desired or practical. 


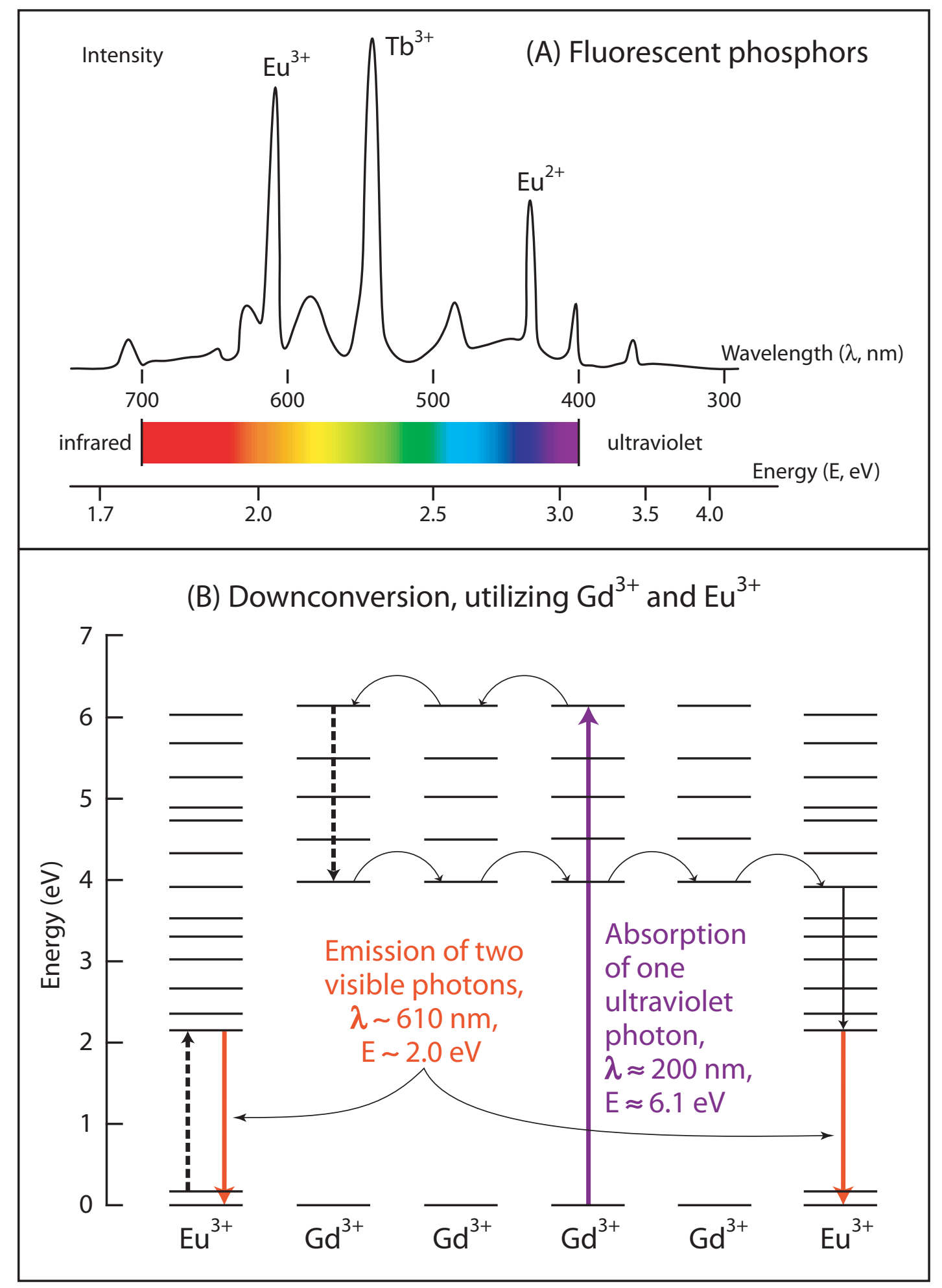

Figure 22. Examples of REE in high-technology phosphors. (A) Emission spectrum of a tricolor fluorescent lamp, with color temperature $4000 \mathrm{~K}$, using phosphors similar though not identical to those described in the text (after Blasse and Grabmaier, 1994). E $\lambda=1240 \mathrm{eV} \mathrm{nm}$. (B) Electronic energy levels (Cotton, 1991) for the $\mathrm{Gd}^{3+}-\mathrm{Eu}^{3+}$ system in LiGdF 4 :Eu, illustrating the principle of downconversion or quantum doubling, whereby one ultraviolet photon is converted to two visible photons (simplified from Wegh and others, 1999). Solid vectors represent absorption or emission of photons. The pair of dashed vectors represents internal excitation of $\mathrm{Eu}^{3+}$ by energy released when excited $\mathrm{Gd}^{3+}$ undergoes a transition to a lower level. Arcs with arrowheads represent radiation-less transfers of energy from one Gd ion to another or to Eu, through the crystal lattice. $1 \mathrm{eV}=8066 \mathrm{~cm}^{-1}$. 


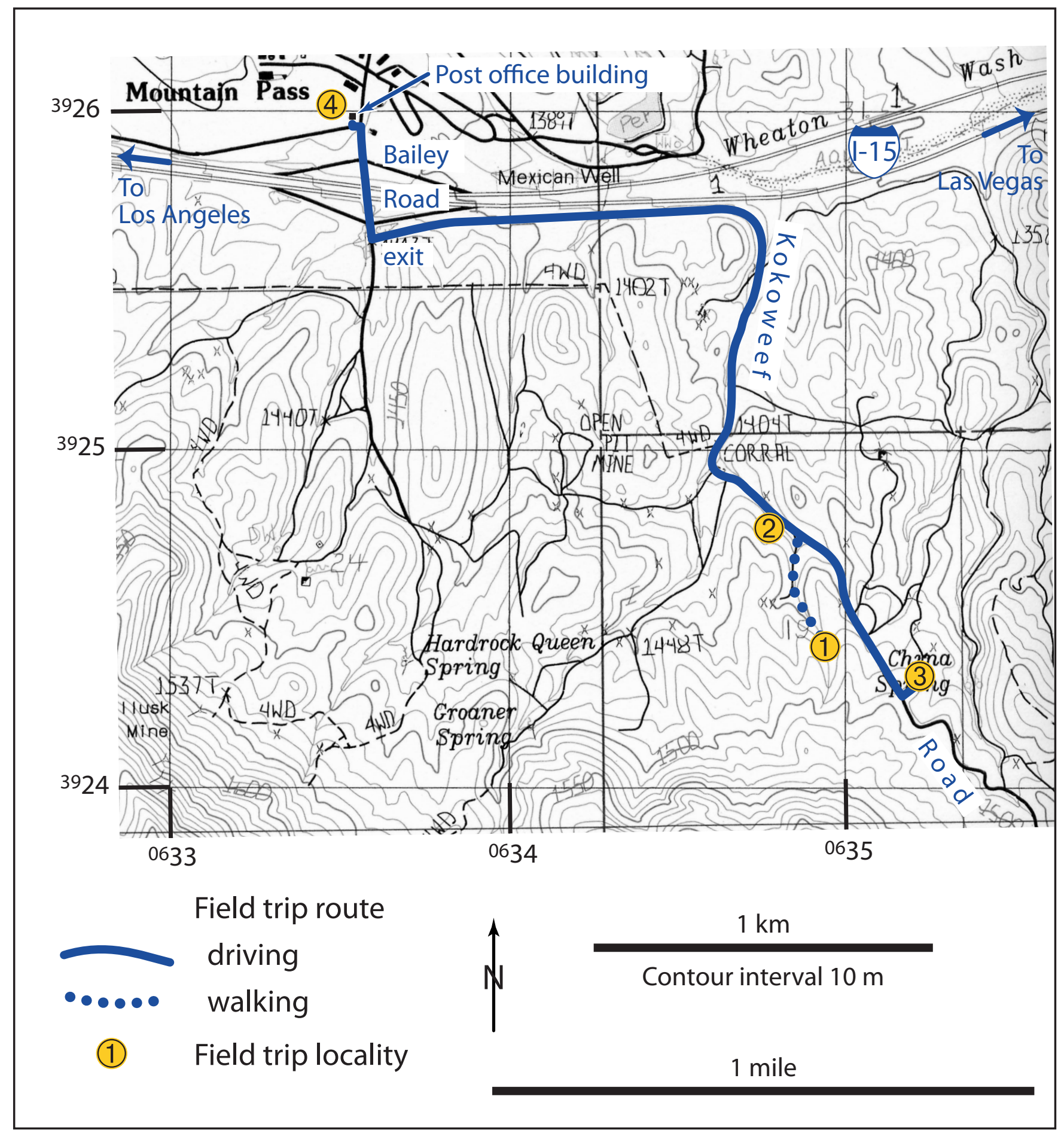

Figure 23. Part of the northeast quadrant of the Mescal Range, California $7.5^{\prime}(1: 24,000)$ topographic quadrangle (provisional edition, 1983), enlarged, showing field trip routes and localities described in the text. 

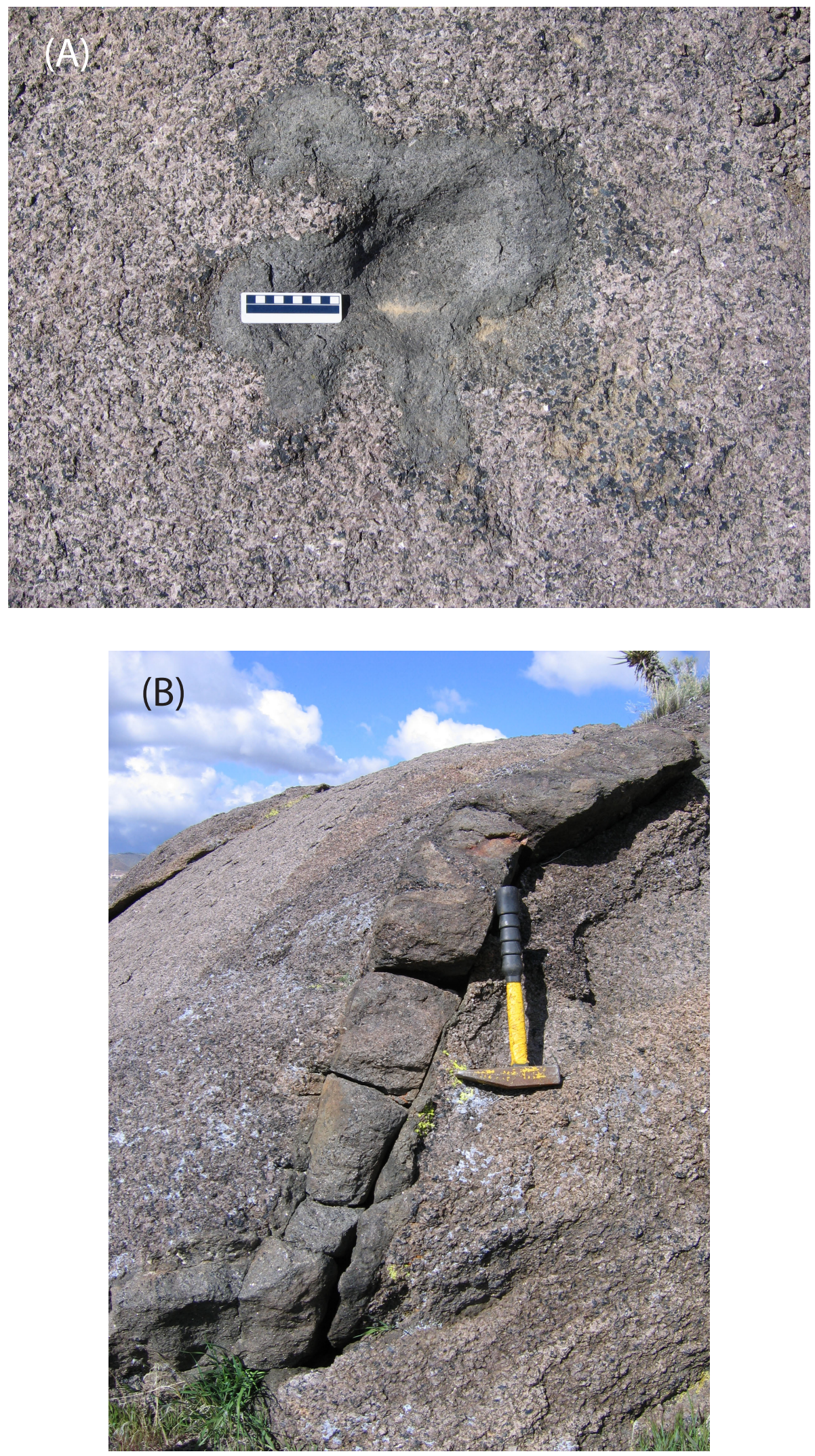

Figure 24. Shonkinite bodies within syenite at field trip locality (1) (Fig. 23). (A) Amoeboid inclusion of shonkinite in syenite. Evidence from nearby outcrops, described in the Appendix, shows that such inclusions are disrupted remnants of early synplutonic shonkinite dikes. Graduations on the scale are 1 and $10 \mathrm{~cm}$.

(B) Late shonkinite dike, intact, intruding syenite. Hammer for scale is $35 \mathrm{~cm}$ long. 